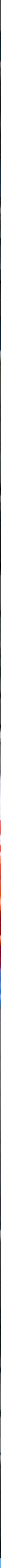

Contaminanten en wetgeving bij mestproducten

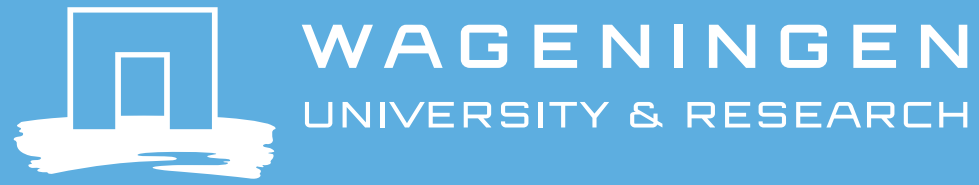





\title{
Contaminanten en wetgeving bij mestproducten
}

Postma R. ${ }^{1}$ P.A.I. Ehlert ${ }^{2}$, W. Van Dijk ${ }^{3}$, J. Roefs ${ }^{4}$ \& L.R. Gollenbeek ${ }^{5}$

\author{
1 Nutriënten Management Instituut NMI BV \\ 2 Wageningen Environmental Research \\ 3 Wageningen Plant Research \\ 4 Nederlands Centrum voor Mestverwaarding \\ 5 Wageningen Livestock Research
}

Dit onderzoek is uitgevoerd door de Stichting Wageningen Research (WR), business units Wageningen Livestock Research en Wageningen Plant Research, in het kader van de publiek private samenwerking (PPS) NL Next Level Mestverwaarden (AF-18136)

Wageningen Livestock Research

Wageningen, September 2020 
Postma R.' P.A.I. Ehlert, W. Van Dijk, J. Roefs \& L.R. Gollenbeek, 2020. Contaminanten en wetgeving bij mestproducten. Wageningen Livestock Research, rapport 1269.

Dit rapport is gratis te downloaden op https://doi.org/10.18174/530719 of op www.wur.nl/livestock-research (onder Wageningen Livestock Research publicaties).

Dit werk valt onder een Creative Commons Naamsvermelding-Niet Commercieel 4.0 Internationaallicentie.

(C) Wageningen Livestock Research, onderdeel van Stichting Wageningen Research, 2020 De gebruiker mag het werk kopiëren, verspreiden en doorgeven en afgeleide werken maken. Materiaal van derden waarvan in het werk gebruik is gemaakt en waarop intellectuele eigendomsrechten berusten, mogen niet zonder voorafgaande toestemming van derden gebruikt worden. De gebruiker dient bij het werk de door de maker of de licentiegever aangegeven naam te vermelden, maar niet zodanig dat de indruk gewekt wordt dat zij daarmee instemmen met het werk van de gebruiker of het gebruik van het werk. De gebruiker mag het werk niet voor commerciële doeleinden gebruiken.

Wageningen Livestock Research aanvaardt geen aansprakelijkheid voor eventuele schade voortvloeiend uit het gebruik van de resultaten van dit onderzoek of de toepassing van de adviezen.

Wageningen Livestock Research is NEN-EN-ISO 9001:2015 gecertificeerd.

Op al onze onderzoeksopdrachten zijn de Algemene Voorwaarden van de Animal Sciences Group van toepassing. Deze zijn gedeponeerd bij de Arrondissementsrechtbank Zwolle.

Wageningen Livestock Research Rapport 1269. 


\section{Inhoud}

$\begin{array}{ll}\text { Woord vooraf } & 5\end{array}$

$\begin{array}{lr}\text { Samenvatting en conclusies } & 7\end{array}$

$1 \quad$ Inleiding $r$

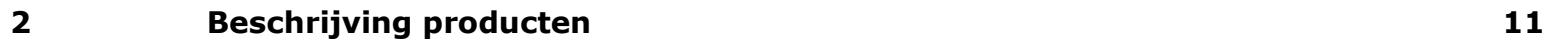

$2.1 \quad$ Minerale producten 11

$\begin{array}{lll}2.2 & \text { Organische producten } & 11\end{array}$

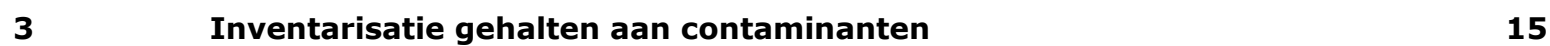

3.1 Zware metalen $\quad 15$

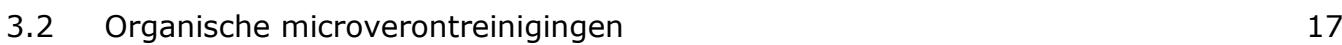

$\begin{array}{lll}3.3 & \text { Antibiotica } & 18\end{array}$

$\begin{array}{lll}3.4 & \text { Pathogene micro-organismen } & 20\end{array}$

$\begin{array}{lll}3.5 & \text { Onkruid, glas en plastic } & 20\end{array}$

$\begin{array}{lll}3.6 & \text { Polymeren } & 21\end{array}$

$4 \quad$ Huidige en toekomstige wet- en regelgeving voor PMC's 22

$\begin{array}{lll}4.1 & \text { Europese wet- en regelgeving } & 22\end{array}$

4.1.1 Huidige Europese regelgeving voor vrijhandelsverkeer, EU/2003/2003 22

4.1.2 Nieuwe Europese Meststoffenverordening 2019/1009 23

4.1.3 Nitraatrichtlijn en JRCs project Safemanure 27

$4.2 \quad$ Nationale wet- en regelgeving $\quad 28$

$\begin{array}{ll}4.2 .1 \text { Nederland } & 28\end{array}$

4.2.2 Duitsland 30

$5 \quad$ Toetsing van producten aan Europese wetgeving 32

5.1 Mineraal N-product (5\%) Nederland, Duitsland en Frankrijk 32

5.2 Mineraal N-product (15-20\%) Nederland, Duitsland, Frankrijk en overig 34

5.3 K-product (5\%) Nederland, Duitsland, Frankrijk en grondstof 35

5.4 Mineraal P-product. Duitsland, Frankrijk en Polen 37

5.5 P-houdend OS-product ( $85 \%$ ds) Duitsland, Frankrijk, Polen en Oekraïne 38

5.6 P-houdend OS-product ( $50 \%$ ds) Duitsland en Frankrijk 40

$\begin{array}{lll}5.7 & \text { P-arm OS-product Nederland } & 41\end{array}$

6 $\begin{array}{ll}\text { Conclusies } & 43\end{array}$

6.1 Risico van aanwezigheid contaminanten $\quad 43$

$\begin{array}{lll}6.2 & \text { Europese wet- en regelgeving } & 44\end{array}$

$\begin{array}{lr}\text { Literatuur } & 46\end{array}$

$\begin{array}{llr}\text { Bijlage } 1 & \text { Overzicht Product-Markt Combinaties } & 48\end{array}$

Bijlage 2 Overzicht inhoud Verordening (EG) nr. 2003/2003 49

Bijlage 3 Verordening (EU) 2019/1009 van het Europees Parlement en de Raad van 5 juni 2019

Bijlage 4 PMCs en de eisen van Duitse regelgeving volgens de Düngemittelverordnung (DüMV). 



\section{Woord vooraf}

De Nederlandse veehouderij produceert niet alleen hoogstaande producten zoals vlees en zuivel, maar ook de waardevolle grondstof mest. Dierlijke mest van goede kwaliteit is met name van groot belang voor het sluiten van kringlopen, in een klimaatvriendelijke, circulaire voedselproductie. Zes bedrijven in de agrarische sector (Agrifirm, Darling Ingredients International, ForFarmers, Royal Friesland Campina, Van Drie Group en De Heus) hebben, samen met Wageningen University \& Research, het Nederlands Centrum Mestverwaarding (NCM) en het ministerie van LNV, de handschoen opgepakt om tot een transitie rond mest en bemesting te komen. Deze transitie is gericht op het verwaarden van mest tot marktrijpe organische en anorganische bemestingsproducten voor afzet in de land- en tuinbouw in Nederland en daarbuiten.

Het onderzoeksprogramma NL Next Level Mest Verwaarden is een Publiek Private Samenwerking, waarbij het ministerie van LNV en de 6 bedrijven financieren. Het bestaat uit 4 werkpakketten:

1. Kwaliteitseisen specificeren voor marktwaardige, emissiearme bemestingsproducten,

2. Technologieën opschalen waarmee die producten kunnen worden geproduceerd,

3. Op boerderijniveau maatregelen nemen om gewenste grondstoffen voor mestverwaarden te leveren,

4. Komen tot een duurzame, transparante en betrouwbare 'mestketen'.

Het onderzoek wat nu gerapporteerd wordt behoort tot werkpakket 1 en is uitgevoerd door Wageningen Plant Research, Wageningen Livestock Research, Wageningen Environmental Research het NCM en het Nutriënten Management Instituut (NMI). De auteurs danken de financiers voor hun deskundige en waardevolle bijdrage in het onderzoek. Ook danken ze de personen die voor dit rapport zijn geconsulteerd.

Namens het onderzoeksteam:

Nico Verdoes, projectleider 


\section{Samenvatting en conclusies}

Belangrijke aspecten voor de mogelijkheden om de producten uit mestverwaarding te verhandelen en toe te dienen zijn de eventuele aanwezigheid van contaminanten en de van toepassing zijnde wet- en regelgeving. De mogelijke bottlenecks dienen voor deze aspecten in een vroeg stadium in beeld gebracht te worden, zodat daar op kan worden geanticipeerd. Het voorliggende rapport is daarom gericht op de volgende aspecten:

- In beeld brengen van de verwachte gehalten aan contaminanten in de producten, zoals zware metalen, chemische verontreinigingen, antibiotica en micro-organismen.

- Opsporen van mogelijke bottlenecks in de (toekomstige) regelgeving die het verhandelen en toepassen van producten als meststof kunnen belemmeren in de verschillende regio's.

- Aangeven van mogelijkheden om de bottlenecks t.a.v. contaminanten en regelgeving op te heffen.

Uitgangspunt voor de evaluatie vormden de producten die in een voorgaande studie (Van Dijk et al., 2020) zijn geselecteerd en waarvan de verwachte samenstelling is afgeleid. Het betreft twee minerale $\mathrm{N}$-producten, een mineraal K-product en een mineraal P-product en daarnaast een aantal P-rijke organische stofproducten en een P-arm organische stofproduct. De belangrijkste grondstof is varkensdrijfmest of de dikke fractie daarvan.

Het risico van de aanwezigheid van contaminanten in de producten uit mestverwaarding is als volgt:

- De hoogste gehalten aan zware metalen worden gevonden in de organische stofrijke producten. Dit geldt dus vooral voor het mineraal P-product (ca. 30\% OS), de P-rijke organische stofproducten (zowel $50 \%$ en $85 \%$ ds) en het P-arme OS-product. Vooral koper ( $\mathrm{Cu}$ ) en zink ( $\mathrm{Zn}$ ) vormen een aandachtspunt in verband met wettelijke normen (zie verder bij wet- en regelgeving).

- Op basis van schaarse metingen die zijn gedaan aan organische microverontreinigingen in onbewerkte mesten en mineralenconcentraten, is het risico van de overschrijding van normen voor organische microverontreinigingen zeer klein.

- Aangezien het gebruik van antibiotica in de veehouderij tussen 2007 en 2016 flink is afgenomen, zal dat ook gelden voor gehalten aan antibiotica in dierlijke mest. Deze gehalten hangen o.a. af van de opname door het dier en de stabiliteit van het antibioticum in mest. Mestverwerking kan leiden tot een beperkte daling van antibioticaresiduen in mestproducten.

- De belangrijkste ziekteverwekkende (of pathogene) organismen zijn Escherichia coli serotype O157:H7, de Salmonella enterica, Campylobacter spp., Cryptosporidium parvum en Giardia duodenalis. In een onderzoek kwam de pathogene $E$ coli in $44 \%$ van de varkensmestmonsters voor. Het aantal micro-organismen neemt af bij opslag (beperkt bij lage temperaturen), anaerobe vergisting (vooral bij thermofiele vergisting, bij temperaturen van $50-55^{\circ} \mathrm{C}$ ), compostering (vooral bij temperaturen van $60^{\circ} \mathrm{C}$ of hoger), verhitting tot $55^{\circ} \mathrm{C}$ of hoger of bij omgekeerde osmose.

- $\quad$ Bij varkensmest is het risico van het verspreiden van onkruid kleiner dan bij rundveemest. Langdurige opslag, vergisting en ook drogen bij $75^{\circ} \mathrm{C}$ gevolgd door korrelen leidt tot een afname van het aantal vitale onkruidzaden. Het risico van glas- en plastic-vervuiling in mestproducten is zeer klein.

- Bij mestverwerking wordt gebruik gemaakt van vlokmiddelen, waaronder polymeren, zoals polyacrylamide. Op termijn moeten de polymeren in CE-meststoffen volledig biologisch afbreekbaar zijn. 
De Europese regelgeving voor vrijhandelsverkeer van meststoffen en het gebruik van stikstofhoudende bemestingsproducten gebaseerd op dierlijke mest maken ten tijde van het schrijven van dit rapport (voorjaar 2020) een ontwikkeling door die nog niet een eindfase bereikt hebben. Dit betekent dat deze rapportage moet worden beschouwd als voorlopig. In de nieuwe Europese Meststoffenverordening 2019/1009 worden productfunctiecategorieën (PFC's) en bestanddelencategorieën (CMC's) onderscheiden. De verwachting is dat mestproducten kunnen voldoen aan de eisen van CMC 10 Afgeleide producten in de zin van verordening EG nr. 1069/2009, maar aangezien die nog niet zijn ingevuld, is dat nog onzeker. Als voldaan is aan de eisen van de CMC én als mestproducten voldoen aan de eisen van de beschreven PFC's en een conformiteitsbeoordeling is doorlopen, kan een CE-markering worden gevoerd. Vanaf dat moment zijn ze vrij verhandelbaar binnen EU.

Stikstofhoudende meststofproducten die uit dierlijke mest worden vervaardigd worden in principe geclassificeerd als dierlijke mest, waardoor ze vallen onder de gebruiksbepalingen van de Nitraatrichtlijn voor dierlijke mest. Dit betekent dat de maximale gift voor deze en andere producten uit dierlijke mest $170 \mathrm{~kg} \mathrm{~N} / \mathrm{ha} / \mathrm{jaar}$ bedraagt. In het project Safemanure is door het Joint Research Centre (JRC) onderzocht onder welke criteria stikstofhoudende bemestingsproducten uit dierlijke mest volgens dezelfde bepalingen gebruikt kunnen worden als stikstof van gangbare minerale meststoffen (kunstmest). De betreffende producten zijn aangeduid als Recovered Nitrogen from Manure (RENURE). Een belangrijk criterium is dat het $\mathrm{N}$-mineraal-gehalte van $\mathrm{N}$-totaal minimaal $90 \%$ bedraagt.

In Tabel 1 is samengevat hoe de mestproducten uit deze studie kunnen worden ingedeeld in een productfunctiecategorie (PFC) uit de nieuwe Europese Meststoffenverordening 2019/1009, of ze voldoen aan de RENURE-criteria en of er knelpunten worden voorzien m.b.t. bepaalde criteria ten aanzien van contaminanten.

Tabel 1 Samenvatting van de indeling van mestproducten in de PFC's van EU 2019/1009, met opmerkingen en eventueel voorziene knelpunten. Voor toelichting zie tekst.

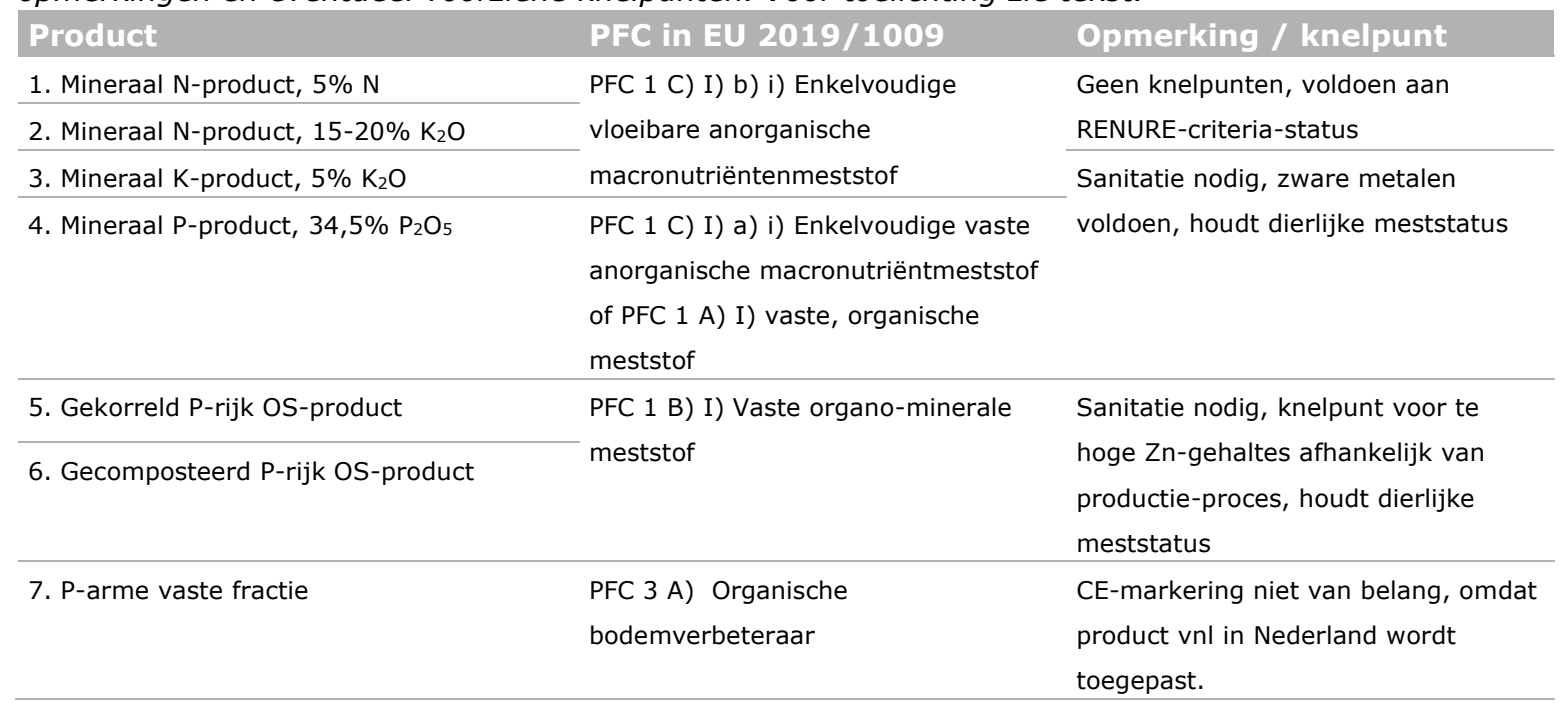

Conclusies:

- Producten 1 en 2 (minerale N-producten met 5 of $15-20 \% \mathrm{~N}$ ) worden ingedeeld in PFC 1 C) I) b) i) Enkelvoudige vloeibare anorganische macronutriëntenmeststof en er zijn geen knelpunten te verwachten ten aanzien van zware metalen. Sanitatie lijkt niet nodig, maar dit is nog onzeker. Ze voldoen aan de RENURE-criteria, waardoor ze niet gebonden zijn aan het maximum van $170 \mathrm{~kg}$ N/ha uit de Nitraatrichtlijn.

- $\quad$ Product 3 (mineraal K-product met 5\% $\mathrm{K}_{2} \mathrm{O}$ ) kan eveneens worden ingedeeld in PFC 1 C) I) b) i) Enkelvoudige vloeibare anorganische macronutriëntenmeststof. Er zijn geen knelpunten te verwachten ten aanzien van zware metalen. Aangezien het organisch koolstofgehalte tussen 2 en $5 \%$ ligt lijkt een sanitatie nodig. Het product voldoet niet aan RENURE-criteria en het houdt de status van dierlijke mest.

- $\quad$ Product 4 (mineraal P-product) kan worden ingedeeld in PFC 1 C) I) a) i) Enkelvoudige vaste anorganische macronutriëntmeststof of als PFC 1 A) I) vaste, organische meststof. Het Zn-gehalte kan mogelijk een knelpunt vormen. Een sanitatie lijkt nodig. Het product voldoet niet aan RENURE-criteria. 
- $\quad$ Producten 5 en 6 (P-rijke OS-producten met $85 \%$ of $50 \%$ DS) kunnen worden ingedeeld in PFC 1 B) I) Vaste organo-minerale meststof. Er is een risico dat Zn-gehalten te hoog zijn, maar wellicht is dit niet het geval als de Zn-gehalten in varkensdrijfmest lager zijn dan de uitgangspunten die in deze studie zijn gehanteerd. Op basis van literatuurgegevens en recentere meetgegevens lijkt dit reëel. Sanitatie van deze producten is nodig.

- $\quad$ Product 7 (P-arme vaste fractie) kan worden ingedeeld in PFC 3 A) Organische bodemverbeteraar. Aangezien dit product vooral in Nederland zal worden toegepast, lijkt een CE-markering voor dit product niet/nauwelijks van belang. Het kan als dierlijke mest in Nederland worden toegepast. 


\section{$1 \quad$ Inleiding}

In 2019 zijn op basis van de nutriënten- en organische stofbehoefte van uiteenlopende landbouwsystemen in binnen- en buitenland een aantal PMC's (combinaties van mestproduct en toepassingsgebied/regio) vastgesteld (Van Dijk et al., 2020-I; bijlage 1). Hierbij is uitgegaan van een ideale samenstelling van mestproducten op basis van nutriënten- en organische stofbehoefte voor verschillende situaties. Vervolgens is in een nog te publiceren studie nagegaan in hoeverre de producten ook daadwerkelijk kunnen worden gemaakt. Verder is op basis van de massabalansen van de benodigde processen een verwachte samenstelling (NPK en organische stof) van de op deze wijze geproduceerde meststoffen afgeleid.

Belangrijke aspecten voor de mogelijkheden om de producten te verhandelen en toe te dienen zijn de eventuele aanwezigheid van contaminanten en de van toepassing zijnde wet- en regelgeving. De mogelijke bottlenecks dienen voor deze aspecten in een vroeg stadium in beeld gebracht te worden, zodat daar op kan worden geanticipeerd.

Daarom wordt daar in dit rapport op ingegaan. Het doel van deze activiteit is om mogelijke bottlenecks in beeld te brengen die het verhandelen en toepassen van producten als meststof belemmeren. Dit richt zich op de volgende aspecten:

- In beeld brengen van de verwachte gehalten aan contaminanten in de producten, zoals zware metalen, chemische verontreinigingen, antibiotica en micro-organismen.

- Opsporen van mogelijke bottlenecks in de (toekomstige) regelgeving die het verhandelen en toepassen van producten als meststof kunnen belemmeren.

- Aangeven van mogelijkheden om de bottlenecks t.a.v. contaminanten en regelgeving op te heffen.

In de volgende hoofstukken zal achtereenvolgens worden ingegaan op de volgende onderdelen: Een beschrijving van de te beschouwen producten, inclusief de grondstoffen, de productieprocessen en de verwachte samenstelling. Dit wordt grotendeels gebaseerd op activiteiten die het afgelopen jaar zijn uitgevoerd in het kader van de PPS Next level mestverwaarden en wordt uitgevoerd in nauwe samenwerking met het onderdeel 'nutriënten en organische stof' (Van Dijk et al., 2020-II), zodat we een gezamenlijke basis hebben. Daarnaast wordt aandacht besteed aan de te verwachten spreiding in de waardegevende bestanddelen, aangezien hiervoor in de nieuwe EU-meststoffenverordening toleranties zijn opgenomen.

Een inventarisatie van te verwachten gehalten aan contaminanten in de beschouwde producten. Naast de gehalten aan zware metalen, die in het voorgaande onderdeel worden meegenomen, wordt daarin ook gekeken naar organische microverontreinigingen, antibiotica en eventuele andere veterinaire stoffen, pathogene micro-organismen, onkruidzaden, glas en plastic en polymeren.

Vervolgens zal in hoofdstuk 4 worden ingegaan op de relevante wet- en regelgeving op Europees en nationaal niveau en zal ook aandacht worden besteed aan kwaliteitssystemen, zoals Global-GAP. Vooral de vernieuwde Europese meststoffenverordening krijgt hierbij veel aandacht, omdat dit van groot belang is voor de verhandelbaarheid van meststoffen binnen Europa vanaf juli 2022.

In hoofdstuk 5 zal een toetsing van de beschouwde producten aan de relevante wet- en regelgeving worden uitgevoerd. In het laatste hoofdstuk worden de conclusies en aanbevelingen beschreven. 


\section{Beschrijving producten}

In dit hoofdstuk wordt een verkorte beschrijving gegeven van de wijze waarop de beschouwde producten worden geproduceerd en wat de verwachte samenstelling van de producten is. Een uitgebreidere beschrijving van de productiewijze zal worden opgenomen in een rapportage, te verschijnen eind 2020. Voor het berekenen van de verwachte samenstelling van de beschouwde producten is uitgegaan van literatuurgegevens over de gemeten samenstelling van grondstoffen (hierbij is vooral gebruik gemaakt van Hoeksma et al., 2011) en massabalansen, waarbij o.a. aannames zijn gedaan ten aanzien van scheidingsrendementen. Zo is er voor de verdeling van de $\mathrm{Mg}$, $\mathrm{S}$, micronutriënten en zware metalen over de mestfracties vanuit gegaan dat die zijn gekoppeld aan de verdeling van organische stof.

In Tabel 2.1 is de verwachte samenstelling van de producten weergegeven, waarbij de gehalten in de praktijk hiervan af kunnen wijken door onnauwkeurigheden bij de gedane aannames. Benadrukt moet worden dat de geschatte samenstelling is gebaseerd op de hierboven genoemde aannames en daarom moeten worden beschouwd als indicatief.

\subsection{Minerale producten}

Bij het maken van de minerale $\mathrm{N}$-producten is uitgegaan van een stripproces, waarbij de ammoniak uit de dunne fractie is opgevangen. Bij het minerale $\mathrm{N}$-product met $5 \% \mathrm{~N}$ is uitgegaan van een strippen met zwavelzuur. De stikstof bestaat volledig uit $\mathrm{NH}_{4}-\mathrm{N}$ en door het gebruik van zwavelzuur bevindt zich ook zwavel in het product. Bij het minerale $\mathrm{N}$-product met $20 \% \mathrm{~N}$ is uitgegaan van een strippen met behulp van salpeterzuur, omdat met zwavelzuur een $\mathrm{N}$-gehalte van $15-20 \%$ niet te realiseren is. De aanwezige $\mathrm{N}$ bestaat uit $\mathrm{NH}_{4}-\mathrm{N}$ en $\mathrm{NO}_{3}-\mathrm{N}$ in een gelijke verhouding. Er komt geen zwavel mee. Aangenomen wordt dat er geen organisch materiaal meekomt en dat het gehalte Corganisch lager is dan 1\%, maar in de praktijk kan er bij strippen toch organisch materiaal in het eindproduct terecht komen.

Het minerale K-product betreft de resterende dunne fractie na het strippen van de ammoniak. Er zijn drie soorten kali-producten onderscheiden:

een concentraat na vergisting - scheiding - $\mathrm{NH}_{3}$-strippen - omgekeerde osmose

een concentraat na scheiding - $\mathrm{NH}_{3}$-strippen - omgekeerde osmose

een concentraat na scheiding - microfiltratie - omgekeerde osmose

Naast kali ( $50 \mathrm{~kg} \mathrm{~K}{ }_{2} \mathrm{O} /$ ton) bevat het product ook $\mathrm{N}$ en $\mathrm{P}_{2} \mathrm{O}_{5}$. De $\mathrm{N}$ is deels aanwezig in minerale vorm $\left(\mathrm{NH}_{4}-\mathrm{N}\right)$ en deels als organische $\mathrm{N}$. Het organische stofgehalte (4-10\%) in de producten is te hoog om als een mineraal product te kunnen worden aangemerkt. Bij toepassing van een extra micro-

filtratiestap (product 3 ) is het organische stof- en N/P-gehalte veel lager.

Het minerale P-product bevat naast P (circa 345 kg $\mathrm{P}_{2} \mathrm{O}_{5} /$ ton) ook N, kali en zwavel. De aanwezigheid van zwavel is een gevolg van gebruik van zwavelzuur bij het productieproces. Voorafgaand aan de Pextractie wordt de dikke fractie eerst aangezuurd met zwavelzuur. De $\mathrm{N}$ is grotendeels aanwezig in de vorm van organische $\mathrm{N}$. Het organische stofgehalte (ca. $30 \%$ ) is ruim te hoog om als een mineraal product te kunnen worden aangemerkt.

\subsection{Organische producten}

$\mathrm{Er}$ is onderscheid gemaakt tussen P-rijke organische producten (gedroogde korrels en compost), bedoeld voor de exportmarkt, en een P-arm organische stofproduct, bedoeld voor de binnenlandse markt. 


\section{P-rijke organische stofproduct}

In Tabel 2.1 zijn alle organische stofproducten weergegeven. Dit betreft twee typen gedroogde en gepelletteerde vaste fracties (korrels) en een gecomposteerde vaste fractie. Bij de korrels is naast normaal gedroogde korrels ook een variant meegenomen, waarbij in het droogproces gebruik is gemaakt van een composteringsstap (biologische droging). Dat levert totaal drie hoofdproducten. Bij alle drie hoofdproducten is nog weer onderscheid gemaakt tussen een product enkel op basis van vaste fractie van varkensdrijfmest en een product van een mix van een vaste fractie van varkens- en rundveedrijfmest en droge kippenmest. Dat laatste is gedaan om een product te krijgen met een hoger EOS-gehalte. Daarnaast zijn per hoofdproduct varianten meegenomen met een $\mathrm{P}_{2} \mathrm{O}_{5}: \mathrm{K}_{2} \mathrm{O}-$ verhouding van $1: 2$ en $1: 1$ (naast $1: 3$ ). Een verhouding van $1: 3$ past meer bij een gewas als aardappelen, terwijl een 1:2- en 1:1-verhouding meer bij graan past. Bij alle P-rijke organische stofproducten is sprake van bijmenging met $\mathrm{N}$ - en/of $\mathrm{K}$-kunstmest om de verhoudingen tussen $\mathrm{N}, \mathrm{P}$ en $\mathrm{K}$ te variëren.

Zodoende zijn er twaalf verschillende producten onderscheiden die zich onderscheiden in NPKsamenstelling en (effectieve) organische stofgehalte (Tabel 2.1 en tabel 2.2).

\section{Opmerking}

Bij de gedroogde korrel is uitgegaan van gebruik van onvergiste vaste fracties als uitgangsmateriaal. Indien in het gekozen proces geen compostering plaatsvindt, zou een vergistingsstap logisch zijn t.b.v. een stabielere vaste fractie. Dat zal wel een iets andere samenstelling geven van de ingaande varkensmest.

\section{P-arm product}

Dit betreft de resterende vaste fractie na extractie van P. Uit de samenstelling blijkt dat het P-gehalte van deze vaste fractie nog steeds aan de hoge kant is, om als organische stofproduct te kunnen worden ingezet.

\section{Opmerking}

Evenals bij korrelproducten voor de export, is ook hier de vraag of een vergistings- of composteringsstap niet zinvol is.

De basis van deze producten is de vaste fractie van varkensmest. De samenstelling hiervan is gebaseerd op monitoringsgegevens van de pilot mineralenconcentraten (Hoeksma et al., 2011). Hierbij is het gemiddelde genomen van drie installaties met een proces vergelijkbaar met dat van de Next-level producten. Vervolgens is op basis van de massabalansen de samenstelling afgeleid van de organische stofproducten.

Bij een deel van de mestproducten is naast vaste fractie van varkensmest ook vaste fractie van rundveemest en droge kippenmest gebruikt (zie hierboven). Voor de samenstelling van de vaste fractie van de rundveemest is voor de $\mathrm{Mg}, \mathrm{S}$ en micronutriënten uitgegaan van de gehalten in rundveedrijfmest (o.a. Handboek Bodem en Bemesting, Römkens \& Rietra, 2008), waarna vervolgens is aangenomen dat deze nutriënten zich verdelen als OS over de mestfracties en dat $20 \%$ van de massa terechtkomt in de vaste fractie. Voor de samenstelling van droge kippenmest is uitgegaan van Handboek Bodem en Bemesting (Mg) en Römkens \& Rietra (2008).

\section{Referentiemeststoffen}

Naast de vastgestelde PMC's zijn als referentie dierlijke mestproducten zoals rundvee- en varkensdrijfmest meegenomen daarnaast is GFT-compost meegenomen als referentie. 
Tabel 2.1 Samenstelling beoordeelde producten: Organische stof en (semi) macro-nutriënten (kg/ton).

\begin{tabular}{|c|c|c|c|c|c|c|c|c|c|c|c|c|c|}
\hline & Vorm & DS & os & $\mathrm{HC}$ & EOS & $\mathrm{N}$-totaal & $\mathrm{NH}_{4}-\mathrm{N}$ & $\mathrm{NO}_{3}-\mathrm{N}$ & $\mathrm{N}$-org & $\mathrm{P}_{2} \mathrm{O}_{5}$ & $\mathrm{~K}_{2} \mathrm{O}$ & $\mathrm{SO}_{3}$ & $\mathrm{MgO}$ \\
\hline \multicolumn{14}{|l|}{ Minerale producten } \\
\hline Mineraal N-product (5\%) & Vloeibaar & 236 & & & & 50 & 50 & & & & & 142 & \\
\hline Mineraal N-product (20\%) & Vloeibaar & 500 & & & & 175 & 87.5 & 87.5 & & & & & \\
\hline Mineraal K-product, vergisting $+\mathrm{RO}$ /ind & Vloeibaar & 153 & 67 & 0.90 & 60 & 13.6 & 5.1 & & 8.5 & 1.0 & 50 & 2.1 & 2.0 \\
\hline Mineraal K-product, pyrolyse + RO/ind & Vloeibaar & 253 & 108 & 0.33 & 36 & 26.8 & 3.5 & & 23.3 & 1.1 & 50 & 2.2 & 2.1 \\
\hline Mineraal K-product, UF + RO/ind & Vloeibaar & 163 & 38 & 0.33 & 13 & 1.0 & 0.8 & & 0.2 & 0.4 & 50 & 2.2 & 2.1 \\
\hline Mineraal P-product & Vast & 850 & 295 & 0.33 & 97 & 10.6 & 1.3 & & 9.3 & 343 & 23 & 148 & 10.6 \\
\hline
\end{tabular}

Referentiemeststoffen

$\begin{array}{lll}35 & 14 & 0.33\end{array}$

$6.9 \quad 6.6$

\section{Organische stofproducten}

Gedroogde vaste fractie, vark P:K=1:3

Gedroogde vaste fractie, vark $P: K=1: 1$

Gedroogde gecomposteerde vaste fractie, vark $\mathrm{P}: \mathrm{K}=1: 3 \quad$ Vast 900

Gedroogde gecomposteerde vaste fractie, vark+kip+rund $P: K=1: 3$ Vast 900

\begin{tabular}{lll}
\hline Gedroogde gecomposteerde vaste fractie, vark $P: K=1: 2$ & Vast & 900 \\
\hline Gedroogde gecomposteerde vaste fractiel, vark $P: K=1: 1$ & Vast & 900
\end{tabular}

Gecomposteerde vaste fractie, vark $P: K=1: 3$

Gecomposteerde vaste fractie, vark+kip+rund $P: K=1: 3$

Gecomposteerde vaste fractie, vark $P: K=1: 2$

Gecomposteerde vaste farctie, vark $P: K=1: 1$

P-arme vaste fractie -

Referentiemeststoffen

$\begin{array}{ll}\text { Vast } & 900 \\ \text { Vast } & 900 \\ \text { Vast } & 900 \\ \text { Vast } & 900\end{array}$

$\begin{array}{lllll}\text { Vast } & 900 & 472 & 0.9 & 424 \\ & 557 & 0.9 & 502\end{array}$

Vast $\quad 669$

$\begin{array}{ll}\text { Vast } & 669 \\ \text { Vast } & 578\end{array}$

Vast $\quad 574$

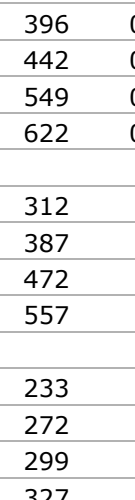

$0.33 \quad 132$

$\begin{array}{ll}0.54 & 239 \\ 0.33 & 183 \\ 0.33 & 207\end{array}$

64.2

$\begin{array}{ll}64.2 & 23.8\end{array}$

$\begin{array}{lll}23.8 & 23.8 & 16.6 \\ 14.7 & 14.7 & 24.9\end{array}$

$\begin{array}{llll}21.6 & 0.7 & 14.7 & 24.9 \\ 22.0 & 0.7 & 20.9\end{array}$

$\begin{array}{ll}21.6 & 0.7 \\ 22.0 & 0.7\end{array}$

0.7

73.2

23.1

\begin{tabular}{|lllllll}
\hline 3.1 & 23.1 & 27.1 & 34 & 102 & 19.8 & 16.9 \\
\hline
\end{tabular}

349

02

$\begin{array}{ll}20.8 & 1.2 \\ 21.3 & 1.4\end{array}$

1.4

19.6

$\begin{array}{lllll}27.1 & 34 & 102 & 19.8 & 16.9 \\ 19.6 & 24 & 71 & & \\ 19.9 & 52 & 61 & 30.2 & 25.8\end{array}$

\begin{tabular}{ccccc} 
& 52 & 61 & 30.2 & 25.8 \\
\hline & 104 & 61 & 35.5 & 30.3
\end{tabular}

Vast 534

$0.9 \quad 244$

56.8

$21.1 \quad 21.1 \quad 14.7$

25

76

\begin{tabular}{llllllll}
36.0 & 8.4 & 8.4 & 19.1 & 25 & 76 & 14.8 & 12.6 \\
\hline
\end{tabular}

Vast $\quad 534$

$\begin{array}{lll}327 & 0.9 & 269 \\ & 0.9 & 294\end{array}$

$\begin{array}{ll}17.7 & 0.5\end{array}$

$\begin{array}{ll}17.5 & 0.6\end{array}$

0.6

23.8

$\begin{array}{ll}14 & 42 \\ 33 & 65\end{array}$

\begin{tabular}{lll}
76 & 14.8 & 12.6 \\
\hline & &
\end{tabular}

$\begin{array}{lll}65 & 19.0 & 16.2\end{array}$

Vast 323

$\begin{array}{llll}228 & 0.33 & 75 & 11\end{array}$

$1.8 \quad 4$

4.6

\begin{tabular}{lll}
36 & 19.0 & 16.2 \\
\hline & 20.8 & 17.8
\end{tabular}


Tabel 2.2 Samenstelling beoordeelde producten: Micronutriënten en zware metalen (g/ton).

\begin{tabular}{|c|c|c|c|c|c|c|c|c|c|c|c|c|c|c|}
\hline & Vorm & B & $\mathrm{Cu}$ & $\mathrm{Zn}$ & Mn & Co & Mo & $\mathrm{Fe}$ & Cd & $\mathrm{Cr}$ & $\mathrm{Ni}$ & As & $\mathrm{Hg}$ & $\mathbf{P b}$ \\
\hline \multicolumn{15}{|l|}{ Minerale producten } \\
\hline Mineraal $\mathrm{N}$-product $(5 \%)$ & Vloeibaar & & & & & & & & & & & & & \\
\hline Mineraal N-product (15-20\%) & Vloeibaar & & & & & & & & & & & & & \\
\hline Mineraal K-product, vergisting + RO/ind & Vloeibaar & 7 & 31 & 134 & 42 & 0.05 & 0.25 & 234 & 0.02 & 0.46 & 0.78 & 0.18 & 0.01 & 0.54 \\
\hline Mineraal K-product, pyrolyse + RO/ind & Vloeibaar & 7 & 32 & 140 & 44 & 0.05 & 0.26 & 243 & 0.02 & 0.48 & 0.81 & 0.19 & 0.01 & 0.56 \\
\hline Mineraal K-product, UF + RO/ind & Vloeibaar & 7 & 33 & 143 & 45 & 0.05 & 0.27 & 249 & 0.02 & 0.49 & 0.83 & 0.20 & 0.01 & 0.58 \\
\hline Mineraal P-product & Vast & 32 & 152 & 686 & 277 & 0.67 & 1.97 & 1146 & 0.01 & 2.35 & 3.19 & 0.82 & 0.06 & 2.43 \\
\hline
\end{tabular}

\section{Referentiemeststoffen}

\begin{tabular}{|c|c|c|c|c|c|c|c|c|c|c|c|c|c|c|}
\hline Tripelsuperfosfaat & Vast & & 37 & & & & & & 24 & 164 & 48 & 0.10 & 0.03 & 6 \\
\hline Mineralenconcentraat & Vloeibaar & 3 & 1 & 7 & 2 & 0.08 & 0.03 & 27 & 0.01 & 0.24 & 0.54 & & & \\
\hline \multicolumn{15}{|l|}{ Organische stofproducten } \\
\hline Gedroogde vaste fractie, vark $P: K=1: 3$ & Vast & 43 & 204 & 921 & 373 & 0.90 & 2.65 & 1539 & 0.02 & 3.15 & 4.29 & 1.11 & 0.08 & 3.26 \\
\hline Gedroogde vaste fractie, mix P:K=1:3 & Vast & & 113 & 323 & & & & & 0.16 & 4.26 & 3.54 & 1.16 & 0.07 & 4.39 \\
\hline Gedroogde vaste fractie, vark $P: K=1: 2$ & Vast & 59 & 282 & 1277 & 516 & 1.24 & 3.67 & 2133 & 0.02 & 4.37 & 5.94 & 1.53 & 0.11 & 4.52 \\
\hline Gedroogde vaste fractie, vark $P: K=1: 1$ & Vast & 67 & 319 & 1446 & 585 & 1.41 & 4.15 & 2414 & 0.03 & 4.95 & 6.73 & 1.74 & 0.13 & 5.11 \\
\hline Gedroogde gecomposteerde vaste fractie, vark $\mathrm{P}: \mathrm{K}=1: 3$ & Vast & 50.6 & 241 & 1092 & 442 & 1.1 & 3.1 & 1824 & 0.02 & 3.7 & 5.1 & 1.31 & 0.10 & 3.86 \\
\hline Gedroogde gecomposteerde vaste fractie, mix $P: K=1: 3$ & Vast & & 127 & 362 & & & & & 0.18 & 4.8 & 4.0 & 1.30 & 0.08 & 4.93 \\
\hline Gedroogde gecomposteerde vaste fractie, vark $\mathrm{P}: \mathrm{K}=1: 2$ & Vast & 77.1 & 368 & 1663 & 673 & 1.6 & 4.8 & 2778 & 0.03 & 5.7 & 7.7 & 2.00 & 0.15 & 5.88 \\
\hline Gedroogde gecomposteerde vaste fractiel, vark $P: K=1: 1$ & Vast & 90.5 & 432 & 1953 & 790 & 1.9 & 5.6 & 3262 & 0.04 & 6.7 & 9.1 & 2.34 & 0.17 & 6.91 \\
\hline Gecomposteerde vaste fractie, vark $P: K=1: 3$ & Vast & 38 & 180 & 815 & 330 & 0.79 & 2.34 & 1361 & 0.02 & 2.79 & 3.79 & 0.98 & 0.07 & 2.88 \\
\hline Gecomposteerde vaste fractie, mix $P: K=1: 3$ & Vast & & 84 & 158 & & & & & 0.17 & 4.0 & 3.0 & 1.04 & 0.07 & 3.79 \\
\hline Gecomposteerde vaste fractie, vark $\mathrm{P}: \mathrm{K}=1: 2$ & Vast & 49 & 231 & 1047 & 424 & 1.02 & 3.01 & 1749 & 0.02 & 3.58 & 4.87 & 1.26 & 0.09 & 3.70 \\
\hline Gecomposteerde vaste fractie, vark $\mathrm{P}: \mathrm{K}=1: 1$ & Vast & 53 & 253 & 1146 & 464 & 1.12 & 3.29 & 1914 & 0.02 & 3.92 & 5.33 & 1.38 & 0.10 & 4.05 \\
\hline P-arme vaste fractie & Vast & 25 & 117 & 530 & 215 & 0.52 & 1.52 & 886 & 0.01 & 1.82 & 2.47 & 0.64 & 0.05 & 1.88 \\
\hline \multicolumn{15}{|l|}{ Referentiemeststoffen } \\
\hline Rundveedrijfmest & Vloeibaar & 3 & 11 & 17 & & & & & 0.02 & 0.54 & 0.38 & 0.13 & 0.01 & 0.40 \\
\hline Varkensdrijfmest & Vloeibaar & 5 & 29 & 69 & 32 & & 0.19 & 176 & 0.03 & 0.59 & 0.67 & 0.14 & 0.01 & 0.41 \\
\hline GFT-compost & Vast & & 19 & 142 & & & & & 0.33 & 11.14 & 6.96 & 2.64 & 0.09 & 54.29 \\
\hline
\end{tabular}




\section{Inventarisatie gehalten aan contaminanten}

\subsection{Zware metalen}

De gehalten aan zware metalen in de mestproducten worden bepaald door de gehalten in de grondstoffen en de productieprocessen (zie voorgaande hoofdstuk). De verwachting is dat die gehalten verwaarloosbaar zijn in de minerale $\mathrm{N}$-producten (deze producten zijn verkregen door strippen van ammoniak, waardoor in principe een zuiver N-product wordt verkregen), maar dat er in de overige producten wel sprake kan zijn van significante gehalten aan zware metalen.

$\mathrm{Er}$ is gebruik gemaakt van de volgende bronnen voor het afleiden van de gehalten aan zware metalen in de mestproducten:

- Ehlert et al. (2009) en Hoeksma et al. (2011): in het kader van de pilot mineralenconcentraten is een groot aantal metingen gedaan in onbewerkte mest en/of digestaat, dunne fracties, dikke fracties en mineralenconcentraten op 7 pilotbedrijven. De producten waarin is gemeten verschilden enigszins tussen bedrijven. Op 6 van de 7 bedrijven was de grondstof (digestaat van) varkensdrijfmest en op één bedrijf digestaat van rundveedrijfmest (met covergistingsmaterialen). Zware metalen die zijn gemeten waren cadmium (Cd), chroom ( $\mathrm{Cr}$ ), koper (Cu), nikkel (Ni) en zink (Zn). Gehalten in onbewerkte mest die zijn gegeven door Hoeksma et al. (2011) zijn gebruikt voor het berekenen van de zware metalengehalten in het mineraal K-product en de gemiddelde gehalten van de dikke fractie gegeven door Hoeksma et al. (2011) zijn gebruikt voor het berekenen van de zware metalengehalten in de organische stofproducten.

Er zijn geen resultaten gegeven van kwik $(\mathrm{Hg})$, lood $(\mathrm{Pb})$ en arseen $(\mathrm{As})$ in het rapport. Volgens Hoeksma et al. (2011) zijn die stoffen niet aangetroffen. Daarnaast zijn organische microverontreinigingen gemeten (zie verder).

- Schoumans et al. (2017) hebben 6 metingen verricht in een mineraal P-product dat is geproduceerd in het kader van het project 'Meerwaarde mest en mineralen'. Zware metalen die zijn gemeten waren cadmium (Cd), chroom $(\mathrm{Cr})$, koper $(\mathrm{Cu})$, lood $(\mathrm{Pb})$, nikkel $(\mathrm{Ni})$ en zink $(\mathrm{Zn})$. Er zijn geen resultaten gegeven van kwik $(\mathrm{Hg})$ en arseen (As).

- Römkens \& Rietra (2008) hebben zware metalengehalten in een groot aantal onbewerkte dierlijke mesten onderzocht. Het betrof 80 varkensdrijfmesten, 80 rundveedrijfmesten en 40 pluimveedrijfmesten afkomstig van praktijkbedrijven. De gehalten van alle 7 zware metalen ( $C d$, $\mathrm{Cr}, \mathrm{Cu}, \mathrm{Hg}, \mathrm{Ni}, \mathrm{Pb}$ en $\mathrm{Zn}$ ) en arseen (As) zijn gemeten. Daarnaast zijn gehalten aan drogestof, organische stof, stikstof $(N)$ en fosfaat $(P)$ gegeven. De gegevens van $\mathrm{As}, \mathrm{Hg}$ en $\mathrm{Pb}$ uit deze studie zijn gebruikt voor de berekende gehalten in de mestproducten.

- Klein \& Roskam (2018) hebben zware metalengehalten in een groot aantal onbewerkte dierlijke mesten onderzocht. Het betrof 44 varkensdrijfmest, 39 rundveedrijfmesten en 20 pluimveedrijfmesten afkomstig van praktijkbedrijven. De gehalten van alle 7 zware metalen ( $C d$, $\mathrm{Cr}, \mathrm{Cu}, \mathrm{Hg}, \mathrm{Ni}, \mathrm{Pb}$ en $\mathrm{Zn}$ ) en arseen (As) zijn gemeten, maar er zijn geen drogestof- en organisch stofgehalten gegeven. Daardoor waren ze niet bruikbaar om de gehalten in de mestproducten te berekenen. Ze zijn wel gebruikt voor het weergeven van de zware metalengehalten in de referentiemeststoffen.

- $\quad$ Driessen \& Roos (1996) hebben in een groot aantal dierlijke mesten (198 stuks), compost (28 monsters), zuiveringsslib ( 8 monsters) en kunstmest (50 monsters) metingen verricht aan zware metalen en organische microverontreinigingen.

Op basis van de bekende samenstelling van de grondstoffen (varkensdrijfmest, dikke fractie varkensdrijfmest, kunstmest, etc.) en massabalansen voor de productieprocessen van deze meststoffen zijn de verwachte gehalten aan zware metalen in de mestproducten berekend (tabel 2.2). Zoals hiervoor is aangegeven kunnen de gehalten in de praktijk hiervan afwijken door onnauwkeurigheden bij de gedane aannames. De weergegeven gehalten moeten daarom als indicatief worden beschouwd. Aangezien de zware metalengehalten zijn gebonden aan wetgeving (volgende 
hoofdstuk), waarbij de maximaal toegestane gehalten worden uitgedrukt op drogestofbasis, zijn de gehalten uit tabel 2.2 vertaald naar drogestofbasis (Tabel 3.1).

Tabel 3.1 Berekende gehalten aan zware metalen (uitgedrukt op drogestofbasis) in minerale- en OSproducten en mediane waarden van een aantal referentiemeststoffen (op basis van Hoeksma et al., 2011; Römkens \& Rietra, 2008; Schoumans et al., 2017; Klein \& Roskam, 2018). Zie tekst voor toelichting.

\begin{tabular}{|c|c|c|c|c|c|c|c|c|}
\hline \multirow[t]{2}{*}{ Mestproduct } & \multicolumn{8}{|c|}{ Zware metalengehalten in $\mathrm{mg} / \mathrm{kg}$ ds } \\
\hline & As & Cd & $\mathrm{Cr}$ & $\mathrm{Cu}$ & $\mathrm{Hg}$ & Ni & $\mathrm{Pb}$ & $\mathrm{Zn}$ \\
\hline $\begin{array}{l}\text { Mineraal K-product, vergisting + } \\
\text { RO/indampen }\end{array}$ & 1,20 & 0,10 & 2,99 & 203 & 0,09 & 5,07 & 3,55 & 878 \\
\hline $\begin{array}{l}\text { Mineraal K-product, pyrolyse + } \\
\text { RO/indampen }\end{array}$ & 0,76 & 0,07 & 1,88 & 128 & 0,06 & 3,19 & 2,24 & 553 \\
\hline Mineraal K-product, UF + RO/indampen & 1,21 & 0,10 & 2,99 & 204 & 0,09 & 5,08 & 3,56 & 879 \\
\hline Mineraal P-product & 0,97 & 0,02 & 2,76 & 178 & 0,07 & 3,76 & 2,85 & 807 \\
\hline Tripelsuperfosfaat (referentiemeststof) & 0,10 & 24,00 & 164,00 & 37 & 0,03 & 48,00 & 6,00 & 0 \\
\hline Mineralenconcentraat (referentiemeststof) & 0,00 & 0,29 & 6,96 & 31 & 0,00 & 15,65 & 0,00 & 204 \\
\hline \multicolumn{9}{|l|}{ Organische stofproducten } \\
\hline $\begin{array}{l}\text { Korrel: gedroogde vaste fractie, vark, } \\
P: K=1: 3\end{array}$ & 1,23 & 0,02 & 3,50 & 226 & 0,09 & 4,76 & 3,62 & 1024 \\
\hline $\begin{array}{l}\text { Korrel: gedroogde vaste fractie, } \\
\text { vark+kip+rund, } P: K=1: 3\end{array}$ & 1,29 & 0,18 & 4,74 & 126 & 0,08 & 3,93 & 4,88 & 359 \\
\hline $\begin{array}{l}\text { Korrel: gedroogde vaste fractie, vark, } \\
P: K=1: 2\end{array}$ & 1,70 & 0,03 & 4,86 & 313 & 0,13 & 6,60 & 5,02 & 1419 \\
\hline $\begin{array}{l}\text { Korrel: gedroogde vaste fractie, vark, } \\
\mathrm{P}: \mathrm{K}=1: 1\end{array}$ & 1,93 & 0,03 & 5,50 & 355 & 0,14 & 7,48 & 5,68 & 1606 \\
\hline $\begin{array}{l}\text { Korrel: gedroogde gecomposteerde vaste } \\
\text { fractie, vark, } P: K=1: 3\end{array}$ & 1,46 & 0,02 & 4,15 & 268 & 0,11 & 5,65 & 4,29 & 1213 \\
\hline $\begin{array}{l}\text { Korrel: gedroogde gecomposteerde vaste } \\
\text { fractie, vark+kip+rund, } P: K=1: 3\end{array}$ & 1,45 & 0,20 & 5,31 & 141 & 0,09 & 4,41 & 5,48 & 403 \\
\hline $\begin{array}{l}\text { Korrel: gedroogde gecomposteerde vaste } \\
\text { fractie, vark, } P: K=1: 2\end{array}$ & 2,22 & 0,04 & 6,33 & 408 & 0,16 & 8,60 & 6,54 & 1848 \\
\hline $\begin{array}{l}\text { Korrel: gedroogde gecomposteerde vaste } \\
\text { fractie, vark, } P: K=1: 1\end{array}$ & 2,61 & 0,04 & 7,43 & 480 & 0,19 & 10,10 & 7,68 & 2170 \\
\hline $\begin{array}{l}\text { Gecomposteerde vaste fractie, vark, } \\
P: K=1: 3\end{array}$ & 1,46 & 0,02 & 4,17 & 269 & 0,11 & 5,67 & 4,31 & 1219 \\
\hline $\begin{array}{l}\text { Gecomposteerde vaste fractie, } \\
\text { vark+kip+rund, } P: K=1: 3\end{array}$ & 1,80 & 0,29 & 6,99 & 146 & 0,12 & 5,13 & 6,55 & 273 \\
\hline $\begin{array}{l}\text { Gecomposteerde vaste fractie, vark, } \\
P: K=1: 2\end{array}$ & 2,19 & 0,04 & 6,24 & 403 & 0,16 & 8,49 & 6,45 & 1824 \\
\hline $\begin{array}{l}\text { Gecomposteerde vaste fractie, vark, } \\
P: K=1: 1\end{array}$ & 2,58 & 0,04 & 7,35 & 474 & 0,19 & 9,99 & 7,59 & 2146 \\
\hline P-arme vaste fractie & 1,97 & 0,03 & 5,63 & 363 & 0,15 & 7,65 & 5,82 & 1644 \\
\hline
\end{tabular}

\section{Referentiemeststoffen}

\begin{tabular}{|c|c|c|c|c|c|c|c|c|}
\hline $\begin{array}{l}\text { Rundveedrijfmest-dig (Hoeksma et al., } \\
\text { 2011) }\end{array}$ & & 0,11 & & 51 & & & & 203 \\
\hline Rundveedrijfmest (Römkens \& Rietra, 2008) & 1,6 & 0,25 & $<6,4$ & 135 & $<0,12$ & 4,5 & $<4,8$ & 198 \\
\hline Rundveedrijfmest (Klein \& Roskam, 2018) & 0,4 & 0,15 & 18,9 & 112 & & 13,5 & 4,0 & 184 \\
\hline Varkensdrijfmest (Hoeksma et al., 2011) & & 0,20 & & 385 & & 9,6 & & 1661 \\
\hline Varkensdrijfmest (Römkens \& Rietra, 2008) & 1,9 & 0,35 & 8,10 & 404 & $<0,14$ & 9,2 & $<5,6$ & 952 \\
\hline Varkensdrijfmest (Klein \& Roskam, 2018) & 0,5 & 0,28 & 13,70 & 325 & & 12,8 & 3,3 & 992 \\
\hline GFT-compost & 3,80 & 0,47 & 16,00 & 27 & 0,13 & 10,0 & 78,0 & 204 \\
\hline
\end{tabular}


- Cd- en Cr-gehalten in de mineraal K-producten zijn veel lager dan in de referentiemeststof tripelsuperfosfaat;

- $\mathrm{Cu}$ - en $\mathrm{Zn}$-gehalten in de mineraal K-producten zijn veel hoger dan in de referentiemeststoffen tripelsuperfosfaat en mineralenconcentraat;

- $\mathrm{Cu}$ - en $\mathrm{Zn}$-gehalten verschillen sterk tussen de organische stofproducten. Dit is te verklaren door verschillen in de samenstelling van de grondstoffen (al dan niet gecomposteerde varkensdrijfmest, rundveedrijfmest en vaste kippenmest en kunstmesten) en verschillende mengverhoudingen van de grondstoffen.

- Het gemiddelde $\mathrm{Zn}$-gehalte in varkensdrijfmest was in de studie van Hoeksma et al. (2011; deze gegevens zijn gebruikt voor het berekenen van het $\mathrm{Zn}$-gehalte in de mestproducten) aanzienlijk hoger dan in de studies van Römkens \& Rietra (2008) en Klein \& Roskam (2018). Dit kan betekenen dat de $\mathrm{Zn}$-gehaltes in de mestproducten in de praktijk aanzienlijk lager zullen zijn dan hier is berekend.

Hoeksma et al. (2011) stelden vast dat zware metalen op dezelfde manier over mestfracties werden verdeeld als drogestof en dat het grootste deel van de zware metalen dus in de dikke fracties van de mest terechtkwamen. Dit beeld wordt bevestigd door Ehlert \& Hoeksma (2011) die stellen dat vrijwel alle onderzochte mineralenconcentraten voldoen aan de milieutoets, maar dat het grootste deel van de dikke fracties niet voldoet, aangezien $\mathrm{Cu}$ - en Zn-gehalten hoger zijn dan de normen die worden gehanteerd bij de toetsing van stoffen als meststof (CDM, 2016). Dit beeld komt ook naar voren uit tabel 3.1, waarbij in ieder geval de Cu- en $\mathrm{Zn}$-gehalten in de mestproducten veel hoger waren dan in het mineralenconcentraat.

De berekende zware metalengehalten in de mestproducten worden in hoofdstuk 5 vergeleken met de normen volgens de Europese en nationale wet- en regelgeving.

\subsection{Organische microverontreinigingen}

Metingen van organische microverontreinigingen in producten van mestverwerking zijn schaars. Ehlert et al. (2009) en Hoeksma et al. (2011) hebben metingen gedaan aan organische microverontreinigingen in mineralenconcentraten en concludeerden dat er voor de concentraten geen sprake was van een overschrijding van normen die in Nederland worden gehanteerd bij de beoordeling van stoffen waarvoor een toelating als meststof wordt aangevraagd (CDM, 2016).

Eerder hebben Driessen \& Roos (1996) ook metingen verricht aan organische microverontreinigingen in een aantal onbewerkte mesten, composten, zuiveringsslibben en kunstmesten. $\mathrm{Er}$ is gemeten in 4 monsters varkensdrijfmest, in 4 monsters rundveedrijfmest en in 4 monsters vaste pluimveemest. De monsters zijn onderzocht op de gehalten aan dioxinen, bestrijdingsmiddelen, polychloorbifenylen (PCB's), polycyclische aromatische koolwaterstoffen (PAK's) en minerale olie (Tabel 3.2). 
Tabel 3.2 Overzicht van organische microverontreinigingen die door Driessen \& Roos (1996) zijn gemeten.

\begin{tabular}{|c|c|c|c|c|c|c|c|c|c|}
\hline Dioxinen & CAS-nr & Bestrijdingsmiddelen & CAS-nr & $\begin{array}{l}\text { Polychloor- } \\
\text { bifenylen }\end{array}$ & CAS-nr & $\begin{array}{l}\text { Polycyclische aromatische } \\
\text { koolwaterstoffen }\end{array}$ & CAS-nr & Minerale olie & CAS-nr \\
\hline $2,3,7,8-\mathrm{TCDF}$ & & HCB & $118-74-1$ & PCB - 28 & $7012-37-5$ & Acenaphtyleen & $208-96-8$ & \multirow[t]{21}{*}{ Minerale olie } & \multirow[t]{20}{*}{$8012-95-1$} \\
\hline $2,3,7,8-\mathrm{TCDD}$ & $1746-01-6$ & alpha-HCH & $319-84-6$ & PCB - 52 & $35693-99-3$ & Acenaphtheen & $83-32-9$ & & \\
\hline $1,2,3,7,8-\mathrm{PeCDF}$ & & $\mathrm{B}-\mathrm{HCH}$ & $319-85-7$ & PCB - 101 & $37680-73-2$ & Fluoreen & $86-73-7$ & & \\
\hline $2,3,4,7,8-P e C D F$ & & gamma-HCH & $58-89-9$ & PCB - 118 & $31508-00-6$ & Phenanthreen & $85-01-8$ & & \\
\hline 1,2,3,7,8-PeCDD & & Aldrin & $309-00-2$ & PCB - 153 & $35065-27-1$ & Anthraceen & $120-12-7$ & & \\
\hline $1,2,3,4,7,8-\mathrm{H} \times \mathrm{CDF}$ & & Heptachloor (incl. epoxide) & $76-44-8$ & PCB - 138 & $35065-28-2$ & Fluorantheen & $206-44-0$ & & \\
\hline $1,2,3,6,7,8-\mathrm{H} \times \mathrm{CDF}$ & & alpha-Chloordaan & $5103-71-9$ & \multirow[t]{15}{*}{ PCB -180} & \multirow[t]{15}{*}{$35065-29-3$} & Pyreen & $129-00-0$ & & \\
\hline $2,3,4,6,7,8-\mathrm{H} \times \mathrm{CDF}$ & & gamma-Chloordaan & $57-74-9$ & & & Benz(a)anthraceen & $56-55-3$ & & \\
\hline $1,2,3,7,8,9-\mathrm{H} x \mathrm{CDF}$ & & alpha-Endosulfan & $959-98-8$ & & & Chryseen & $218-01-9$ & & \\
\hline $1,2,3,4,7,8-\mathrm{HxCDD}$ & & Dieldrin & $60-57-1$ & & & Benzo(b)fluorantheen & $205-99-2$ & & \\
\hline $1,2,3,6,7,8-\mathrm{H} \times \mathrm{CDD}$ & & Endrin & $72-20-8$ & & & Benzo(k)fluorantheen & $207-08-9$ & & \\
\hline $1,2,3,7,8,9-\mathrm{HxCDD}$ & & DDT (incl. metabolieten) & $50-29-3$ & & & Benzo(a)pyreen & $50-32-8$ & & \\
\hline $1,2,3,4,6,7,8-\mathrm{HpCDF}$ & & \multirow{9}{*}{\multicolumn{2}{|c|}{ Hexachloorbutadiëen }} & & & Indeno(123cd)pyreen & $193-39-5$ & & \\
\hline $1,2,3,4,7,8,9-\mathrm{HpCDF}$ & & & & & & Dibenz(ah)anthraceen & $53-70-3$ & & \\
\hline $1,2,3,4,6,7,8-\mathrm{HpCDD}$ & & & & & & Benzo(ghi)peryleen & $191-24-2$ & & \\
\hline OCDF & & & & & & & & & \\
\hline OCDD & & & & & & & & & \\
\hline Planaire polychloorbife & enylen & & & & & & & & \\
\hline $3,4-3^{\prime}, 4^{\prime}$ PCB $(77)$ & & & & & & & & & \\
\hline $3,4-3^{\prime}, 4^{\prime}, 5^{\prime}$ PCB (126) & & & & & & & & & \\
\hline $3,4,5-3^{\prime}, 4^{\prime}, 5^{\prime}$ PCB (169) & & & & & & & & & \\
\hline
\end{tabular}

De gehalten van al deze stoffen in de mestmonsters waren zeer laag. Hoeksma et al. (2011) stelden op basis van de metingen van Driessen \& Roos (1996) en hun eigen metingen dan ook dat dierlijke mest geen bron is van organische microverontreinigingen en ze verklaren dit doordat bij diervoeding een strikte kwaliteitsborging wordt gehanteerd. De risico's van contaminatie van mest met organische microverontreinigingen worden daarom volgens hen beheerst en uitgesloten. Ook geven ze aan dat bij (co)vergisting van mest de covergistingsmaterialen toegelaten worden op basis van een toetsing aan milieucriteria, waarmee dus ook sprake is van een kwaliteitsborging.

Dit betekent dat bij producten van mestverwerking het risico van de overschrijding van normen voor organische microverontreinigingen zeer klein lijkt te zijn.

\subsection{Antibiotica}

Het antibioticagebruik in de veehouderij staat de afgelopen jaren sterk in de belangstelling, o.a. door het risico van het optreden van antibiotica-resistentie. Vanaf 1999 is een EU-verbod om antibiotica als groeibevorderaar aan diervoeders toe te voegen stapsgewijs ingevoerd, met een volledig verbod vanaf 2006. Als gevolg daarvan is het gebruik van antibiotica in de veehouderij sinds 2007 flink afgenomen (figuur 3.1). Na de snelle daling van het gebruik is de daling na 2012 afgevlakt en stagneert sinds 2016 (Compendium voor de Leefomgeving, 2019). 


\section{Antibioticagebruik veehouderij}

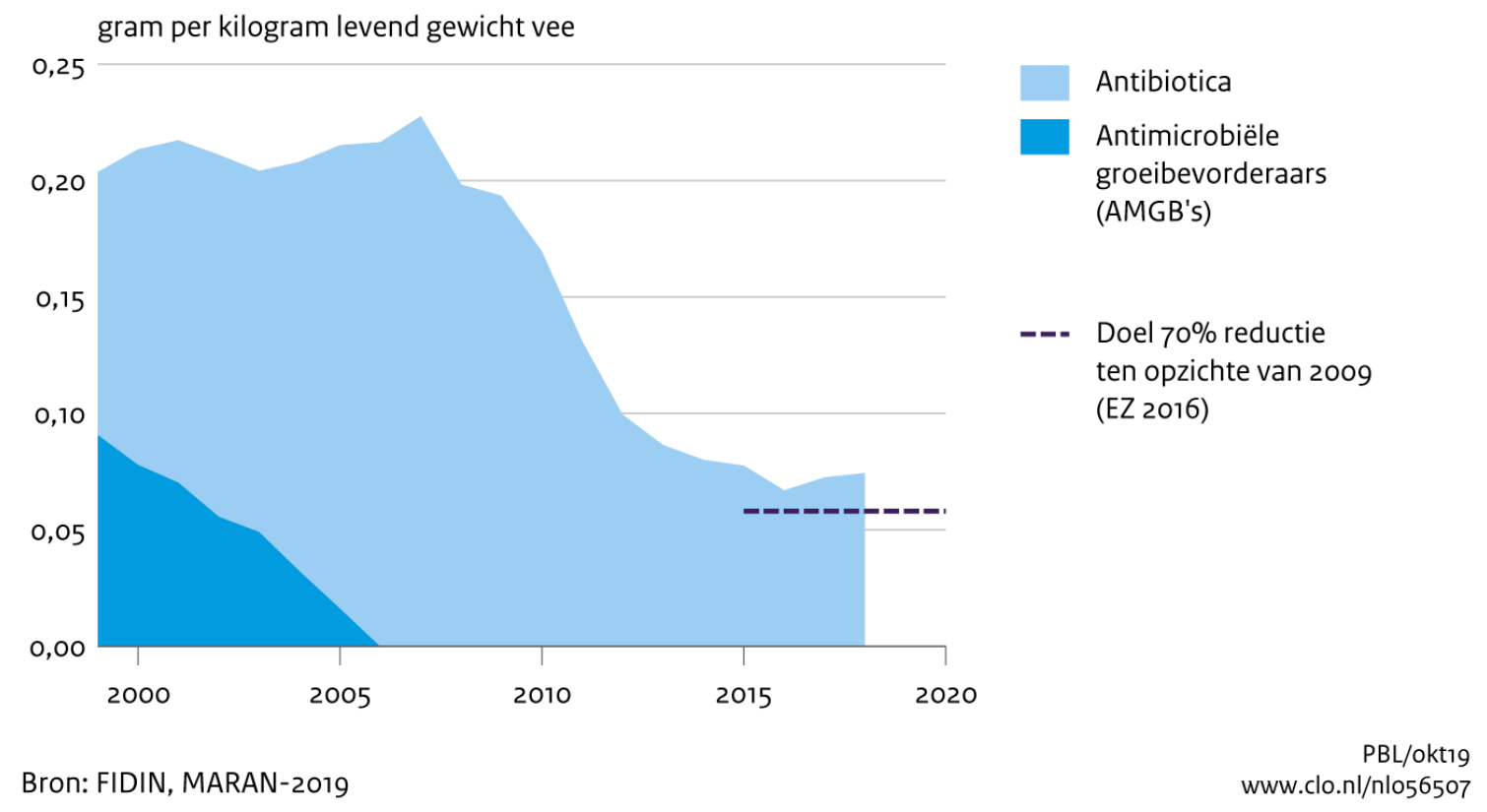

Figuur 3.1 Beloop van het antibioticagebruik in de veehouderij (bron: Compendium voor de Leefomgeving, 2019).

Sinds 2009 is de verkoop van antibiotica voor de veehouderij in 2018 met bijna 64\% gedaald (MARAN-2019). Er is een groot verschil tussen sectoren, waarbij het aantal behandeldagen met antibiotica ten opzichte van 2009 het meest gedaald is bij vleeskuikens (namelijk ongeveer 70\%), terwijl de daling in de varkenshouderij ruim $55 \%$ bedroeg (SDa, 2019). In de vleeskalverhouderij was de daling het minst met 44\%. Vleeskalverhouders en kalkoenhouders behandelden hun dieren in 2018 het vaakst, met respectievelijk 19 en 17 behandeldagen per jaar. Melkkoeien kregen met ruim 3 behandeldagen per jaar het minst vaak antibiotica toegediend.

Het gebruik per ( $\mathrm{kg}$ levend) dier ligt in Nederland beneden het Europees gemiddelde en ver beneden het gebruik van antibiotica in landen als België, Italië en Spanje (EMA, 2018).

Antibiotica kunnen zich o.a. via mest verspreiden in het milieu (bodem, lucht en grond- en oppervlaktewater) en zodoende bijdragen aan het voorkomen en verspreiden van antibioticaresistenties (o.a. Kivits et al., 2017; Schmitt et al., 2017). Het voorkomen van antibioticaresten kan van invloed zijn op bodemfuncties van bacteriën en op concentraties van antibiotica in gewassen. Over de ecologische en landbouwkundige consequenties hiervan is nog veel onduidelijk (Singer et al., 2016) (Lahr et al., 2019).

Door ILVO is onderzoek gedaan naar de verspreiding van antibiotica in het milieu via varkensdrijfmest (Van den Meersche, 2019). Er zijn metingen gedaan aan een groot aantal antibiotica in de mest, waarbij werd geconcludeerd dat de gehalten van de antibiotica in de mest afhingen van de opname door het dier en de stabiliteit van het antibioticum in de mest. Ook is gekeken naar het effect van mestverwerking op de aanwezigheid van antibiotica. Daartoe zijn op twee bedrijven metingen gedaan in verschillende fasen van de mestverwerking. Het effect was vrij klein, maar er werd een beperkte daling van zowel antibioticaresiduen en resistentiegenen na mestverwerking vastgesteld (Van den Meersche, 2019). 


\subsection{Pathogene micro-organismen}

Mest is een risicofactor voor het optreden van ziekten bij de mens, bijvoorbeeld door een besmetting met Escherichia coli serotype 0157:H7 (Hussein \& Bollinger, 2005). Mest bevat over het algemeen miljoenen bacteriën per gram mest, waarvan het merendeel niet ziekteverwekkend is voor de mens, zoals de bacteriën Enterococcus spp. en veel varianten van E. coli. De belangrijkste

ziekteverwekkende organismen zijn, behalve de reeds genoemde E. coli 157, de Salmonella enterica, Campylobacter spp., Cryptosporidium parvum en Giardia duodenalis (Van Leuken et al., 2017).

Pathogenen uit mest kunnen zich verspreiden in het milieu via bodem, water en lucht. Na aanbrengen van mest op of in de bodem, kunnen pathogenen in het water terecht komen via uit- en afspoeling. De mate waarin ziekteverwekkers in het water terecht komen is afhankelijk van meerdere factoren, zoals de bacteriesoort, de wijze waarop mest al dan niet is behandeld, de wijze waarop mest op of in de bodem is aangebracht en de temperatuur en het vochtgehalte. Ziekteverwekkers kunnen zich ook als bioaerosol verplaatsen door de lucht, wat bijvoorbeeld een grote rol heeft gespeeld bij de Q-koorts epidemie in 2007-2010 (Van Leuken et al., 2017).

Van Leuken et al. (2017) verkenden het voorkomen van E. coli en meticilline resistente Staphylococcus aureus (MRSA) in mest en de verspreiding naar het milieu in een literatuurstudie. Ze stelden vast dat de pathogene $E$. coli in $44 \%$ van varkensmestmonsters in de onderzochte studies voorkwamen, terwijl dat bij rundveemest in $17 \%$ van de monsters het geval was. De E. coli kwam in 2-88\% van de onderzochte watermonsters nabij veehouderijbedrijven voor, waarbij de afstand tot de bron een belangrijke factor was. Verder keken ze ook naar het effect van opslag en mestverwerking op de aanwezigheid van de bacteriën in mest, waarbij breder werd gekeken dan alleen de genoemde twee bacteriesoorten. Daarbij leidde een hogere temperatuur en een langere opslag vrijwel altijd tot een lager aantal levende bacteriën.

De effecten van opslag en mestverwerking zijn door Van Leuken et al. (2017) als volgt samengevat:

- Opslag van mest leidt meestal tot een afname van het aantal micro-organismen. Onder Nederlandse omstandigheden, met mesttemperaturen van $10-20{ }^{\circ} \mathrm{C}$, is het effect echter beperkt en zal onbewerkte mest ook na langdurige opslag nog veel micro-organismen bevatten;

- Anaerobe vergisting leidt ook tot een afname van de aantallen micro-organismen, maar daarbij moet onderscheid worden gemaakt naar thermofiele vergisting (temperaturen van 50 $55^{\circ} \mathrm{C}$ ), waarbij vrijwel alle organismen worden geïnactiveerd, en mesofiele vergisting (35-40 ${ }^{\circ} \mathrm{C}$ ) en psychrofiele vergisting $\left(<20^{\circ} \mathrm{C}\right)$, waarbij dat in veel mindere mate het geval is.

- Compostering leidt in het algemeen ook tot een afname van het aantal micro-organismen, maar dit is vooral het geval als de temperatuur stijgt tot $60^{\circ} \mathrm{C}$ of hoger en als voldoende zuurstof beschikbaar is voor het composteringsproces;

- Verhitting tot $55^{\circ} \mathrm{C}$ of hoger leidt in het algemeen tot effectieve inactivatie van microorganismen, maar sporen van bijvoorbeeld Coxiella burnetii of Cryptosporidium spp. kunnen dit overleven;

- Omgekeerde osmose is ook een effectieve manier om micro-organismen te verwijderen, mits de installatie in goede staat is en het membraan niet beschadigd is. Dit resulteert in een concentraat dat als meststof wordt toegepast en een effluent dat op het oppervlaktewater wordt geloosd. Het effluent dat ontstaat na omgekeerde osmose is microbiologisch schoon (Hoeksma et al., 2016).

\subsection{Onkruid, glas en plastic}

Het risico van het verspreiden van onkruid met dierlijke mest hangt af van het soort mest en de behandeling die de mest heeft ondergaan (Elema \& Scheepens, 1992). Bij varkensmest is het risico kleiner dan bij rundveemest en daarnaast leidt langdurige opslag tot een afname van de kiemkracht van onkruidzaden. Vergisting van mest leidt tot een afname van het aantal vitale onkruidzaden en dit effect is bij varkensmest sterker dan bij rundveemest. Een vergistingsduur van 10 dagen wordt als afdoende beschouwd (CDM, 2016). Als de mest wordt gedroogd bij $75^{\circ} \mathrm{C}$ en vervolgens in korrels wordt geperst is het risico van overleving van onkruidzaden zeer gering. 
Verontreinigingen in de vorm van glas en plastic horen niet thuis in meststoffen en zullen normaalgesproken ook niet voorkomen in dierlijke mest. Het risico op de aanwezigheid van deze materialen is wel aanwezig als bermmaaisel of vergelijkbaar materiaal wordt toegepast in het productieproces. Om die reden zijn er normen voor glas en plastic in compost en digestaat (waarbij covergistingsmaterialen in het proces worden gebruikt). Bij de hier beschouwde producten is dat niet aan de orde.

\subsection{Polymeren}

Bij mestverwerking en ook bij drinkwaterbereiding wordt gebruik gemaakt van vlokmiddelen.

Daarvoor wordt gebruik gemaakt van coagulanten, zoals ijzer- en aluminiumzouten, en/of organische flocculanten of polymeren, zoals polyacrylamide (Hoeksma et al., 2011; Doude van Troostwijk, 2002). Vaak worden de coagulanten en flocculanten in combinatie gebruikt. Op termijn moeten de polymeren volledig biologisch afbreekbaar zijn (zie volgende hoofdstuk). 


\section{$4 \quad$ Huidige en toekomstige wet- en regelgeving voor PMC's}

Beoogde PMCs zijn gespiegeld aan vigerende en komende Europese bepalingen en aan nationale bepalingen voor vrijhandelsverkeer. Er zijn diverse ontwikkelingen gaande die invloed hebben op het vrijhandelsverkeer van bemestingsproducten van dierlijke mest en hun gebruik in Nederland en andere lidstaten van EU27. Daarenboven wijzigt regelgeving voortdurend door maatschappelijke ontwikkelingen. Dit hoofdstuk geeft een momentopname (maart 2020). Verifieer bij feitelijke vrije verhandeling altijd of gegeven referenties voor wet- en regelgeving niet inmiddels zijn aangepast.

\subsection{Europese wet- en regelgeving}

4.1.1 Huidige Europese regelgeving voor vrijhandelsverkeer, EU/2003/2003

De huidige Europese Meststoffenverordening ${ }^{1}$ regelt vrije handel in meststoffen en kalkmeststoffen tussen de lidstaten (EU, 2003). Het oogmerk van de huidige meststoffenverordening is om de kwaliteit te reguleren en de gebruiker van meststofproducten te beschermen tegen kwalitatief slechte bemestingsproducten. De kwaliteit van deze bemestingsproducten wordt geregeld door middel van het vaststellen van normen voor:

1. Typeaanduidingen voor meststoffen (bv. kalkammonsalpeter, tripelsuperfosfaat);

2. Omschrijving van het productieproces met belangrijkste bestanddelen;

3. Eisen minimumgehalten aan waardegevende bestanddelen met hun oplosbaarheid (nutriënten) in samenhang met aangewezen geharmoniseerde analysemethoden;

4. Eisen aan etikettering. EU verordening 2003/2003 kent weliswaar een generieke bepaling ${ }^{2}$ t.a.v. milieubezwaarlijkheid en een vrijwaringsclausule maar kent geen regulering van contaminanten via specifieke eisen voor maximum toegestane gehalten ${ }^{3}$.

Bij beantwoording aan de eisen kan het bemestingsproduct met het label "EG-meststof" worden verhandeld en is vrije verhandeling tussen de lidstaten mogelijk. Lidstaten kunnen meststoffen die het label "EG-meststof" voeren niet weigeren. De huidige Europese meststoffenverordening stelt geen eisen aan gebruik of aan contaminanten. Lidstaten kunnen wel specifieke gebruiksbepalingen voeren. De verordening geeft voorschriften. Dit zijn standaarden voor meststofanalyse, bemonstering, menging van meststoffen en verpakking. De voorschriften bestaan uit generieke bepalingen gegeven in hoofdstukken en bijlagen betreffende:
i. Aangewezen EG-meststoffen,
ii. Toleranties voor aangewezen EG-meststoffen,
iii. Technische voorzieningen voor meststoffen met een hoog gehalte aan ammoniumnitraat (om risico's op ontploffing te voorkomen),
iv. Methoden voor bemonstering en analyse,
v. Bepalingen voor controle op naleving en accreditatie,
vi. Administratieve eisen voor nieuwe bemesting materiaal dat kan worden bestempeld als EG meststof.

Bijlage 2 geeft meer detail bij deze hoofdstukken en bijlagen.

De EU Verordening 2003/2003 sluit vrije verhandeling uit van bemestingsproducten met organisch gebonden koolstof en nutriënten van plantaardige en/of dierlijke herkomst (waaronder dierlijke mest).

\footnotetext{
${ }^{1}$ Verordening (EG) nr. 2003/2003 van het Europees Parlement en de Raad van 13 oktober 2003 inzake meststoffen EG/2003/2003, https://eur-lex.europa.eu/legal-content/NL/TXT/?uri=CELEX\%3A32003R2003

${ }^{2}$ EU/2003/2003, Artikel 14 c: Een type meststof wordt uitsluitend in bijlage I opgenomen: indien de meststof onder normale gebruiksomstandigheden geen schadelijke gevolgen heeft voor de gezondheid van mens, dier of plant of voor het milieu.

${ }^{3}$ Een aantal lidstaten heeft een ontheffing (derogatie) voor regulering van het cadmiumgehalte in fosfaatmeststoffen
} 
Daardoor belemmert de huidige regelgeving vrije handel van producten van verwerking van dierlijke mest en bioafval (Ehlert \& Schoumans, 2015). Naast het uitsluiten van organische stof en nutriënten van plantaardige en/of dierlijke herkomst legt EU Verordening 2003/2003 andere beperkingen aan PMCs op, die plaatsing onder deze regelgeving ook uitsluiten waaronder:

- Productieprocessen waarmee bemestingsproducten met organisch gebonden koolstof worden geproduceerd, worden niet beschreven.

- Meststoffen met het label EG-meststof zijn over het algemeen producten met hoge gehalten aan waardegevende bestanddelen, terwijl bemestingsproducten gewonnen uit hernieuwbare hulpbronnen (recycling) heel vaak niet kunnen voldoen aan de huidige gestelde minimumeisen.

- Procestechnologie voor de verwerking van dierlijke mest en bioafval is divers. Ook de samenstelling van dierlijke mest en bioafval is variabel. Bemestingsproducten van verwerkte mest en GFT tonen daardoor meer variatie in samenstelling in vergelijking met de huidige EGmeststoffen op basis van vergelijkbare samenstellende bestanddelen. Door deze variatie kan vaak niet aan criteria voor toleranties worden voldaan.

- Er zijn andere analysemethoden van toepassing die niet door de Europese meststoffenverordening 2003/2003 zijn aangewezen.

- Hergebruik van afvalstoffen met nutriënten, zuur neutraliserende waarde en organische stof als meststof wordt expliciet uitgesloten.

EU Verordening 2003/2003 is sinds de eerste publicatie 13 keer aangepast met uitbreidingen en wijzigingen en twee keer werden rectificaties aangebracht. Een belangrijke uitbreiding vond plaats in 2013 toen kalkmeststoffen ${ }^{4}$ geharmoniseerd werden. De verordening stuurt in detail op productkwaliteit minerale meststoffen en kalkmeststoffen. Conformiteitsonderzoek en markttoezicht is bij deze verordening volledig in handen van nationale autoriteit (in NL is dat de NVWA).

Van de 7 producten zijn er twee die mogelijk in aanmerking zouden kunnen komen om onder bepalingen van de EG Verordening 2003/2003 in het vrij handelsverkeer als meststof gebracht te kunnen worden. Dat zijn product 2 (Mineraal N-product, 15-20\%) en product 4 (Mineraal P-product). Een absolute voorwaarde is dat deze producten geen organische stof bevatten wat in de praktijk niet eenvoudig te realiseren zal zijn. Nutriënten van plantaardige of dierlijke herkomst mogen niet worden toegevoegd. Aangezien de nutriënten volledig van dierlijke herkomst zijn, kan niet aan deze eis worden voldaan. Overige producten bevatten organische stof waardoor zij niet voldoen aan gestelde eisen van EG Verordening 2003/2003.

In 2010 werd de EG Verordening 2003/2003 geëvalueerd (CSES, 2010). De evaluatie resulteerde in een aantal aanbevelingen. Eén ervan was om criteria voor contaminanten op te nemen; een andere om de lijst van minerale meststoffen uit te breiden met andere bemestingsproducten van onder andere dierlijke en plantaardige herkomst. Daarnaast werden overzichten gepubliceerd waaruit bleek dat naast EU Verordening 2003/2003 lidstaten zeer verschillende nationale bepalingen voeren voor vrij-handelsverkeer van meststoffen, hetgeen onwenselijke vormen van handelsbelemmeringen opriep bij - bilateraal - vrij handelsverkeer tussen lidstaten ${ }^{5}$. De evaluatie was de directe aanleiding om EU Verordening 2003/2003 te herzien.

EG Verordening 2003/2003 wordt op 16 juli 2022 ingetrokken (4.1.2).

\subsubsection{Nieuwe Europese Meststoffenverordening 2019/1009}

Op 25 juni 2019 is de nieuwe Europese meststoffenverordening 2019/1009 gepubliceerd na een lang en intensief voorbereidingstraject dat in 2010 startte en onder drie Europese Commissies met verschillende samenstellingen en werkprogramma's uitgevoerd werd. Aanvankelijk was de ambitie om alle nationale regelgeving over vrijhandelsverkeer van meststoffen te vervangen door één verplichtende Europese Verordening. Die ambitie werd terug geschaald. Het resultaat is een

\footnotetext{
${ }^{4}$ Verordening (EU) nr. 463/2013 van de Commissie van 17 mei 2013

${ }^{5}$ Op Europees niveau geldt het principe van wederzijdse erkenning. Dit betekent dat wanneer een product rechtmatig in een lidstaat gemaakt is, dit product in een andere lidstaat niet verboden mag worden. De rechten en plichten staan in Verordening 764/2008/EG. Er wordt alleen een uitzondering gemaakt wanneer er gevaar bestaat voor de openbare veiligheid, de gezondheid of het milieu. Ondanks EU Verordening 764/200/EG dienen bemestingsproducten toch aan nationale bepalingen te voldoen, bv. door een ontheffing van verbodsbepalingen aan te vragen.
} 
facultatieve EU Verordening 2019/1009 naast continuerende bestaande nationale regelgeving voor vrijhandelsverkeer van meststoffen. Facultatief betekent dat de fabrikant van een bemestingsproduct kan kiezen of een CE markering ${ }^{6}$ gevoerd gaat worden of niet. Bij voering van een CE markering gelden de bepalingen van EU Verordening 2019/1009. Ook kan gekozen worden voor nationale weten regelgeving.

EU Verordening 2019/1009 dient om de circulariteit van het gebruik van hernieuwbare grondstoffen voor bemestingsproducten te stimuleren. Bemestingsproducten mogen daardoor gefabriceerd worden uit nutriënten van plantaardige of dierlijke herkomst en/of uit organische stof. Beheersing van risico op ongewenste milieueffecten (milieubezwaarlijkheid) is een nieuw en bepalender oogmerk dan bescherming van de gebruiker.

De opzet van deze nieuwe verordening verschilt van de EG Verordening 2003/2003. De grondslag is Europese horizontale wetgeving waardoor verplichtingen gelden over de informatieplicht en dat er onder andere afstemming is met andere verordeningen gericht op beheersing van enig risico op milieubezwaarlijkheid. De opzet van de nieuwe Europese Meststoffenverordening leidt tot een uitwerking in hoofdstukken en bijlagen die verschilt van de EG Verordening 2003/2003:
I. Algemene bepalingen
II. Verplichtingen van marktdeelnemers
III. Conformiteit van EU bemestingsproducten
IV. Aanmelding van conformiteitsbeoordelingsinstanties
V. Markttoezicht in de Unie, controle van EU-bemestingsproducten die de markt van de Unie binnenkomen en vrijwaringsprocedure van de Unie
VI. Gedelegeerde bevoegdheden en comitéprocedure
VII. Wijzigingen
VIII. Overgangs- en slotbepalingen
Bijlage I. Productfunctiecategorieën (PFC's") van EU-bemestingsproducten
Bijlage II. Bestanddelencategorieën (Component Material Categories - CMC's)
Bijlage III. Etiketteringsvoorschriften
Bijlage IV. Conformiteitsbeoordelingsprocedures
Bijlage V. EU conformiteitsverklaring

Bijlage 2 geeft meer achtergronden bij deze hoofdstukken en bijlagen.

De verordening focust op de verplichtingen die gesteld worden aan marktdeelnemers (fabrikanten, distributeurs, importeurs (in EU27) en gemachtigden) en conformiteitsbeoordeling. Alleen bij markttoezicht is de nationale autoriteit in beeld. De verordening stelt de interne EU markt open voor alle bemestingsproducten mits aan bepaalde voorwaarden voor veiligheids-, kwaliteits- en etiketteringsvoorschriften voor alle meststoffen wordt voldaan.

De uitgebreide positieve lijst van minerale meststoffen en kalkmeststoffen die EG Verordening 2003/2003 voorschrijft, komt te vervallen. Daarvoor in de plaats komen zeven productfunctiecategorieën (product function categories, PFCs, tabel 4.1). Bemestingsproducten van deze PFCs mogen uitsluitend gefabriceerd worden uit aangewezen - schone - grondstoffen die aangewezen worden in bestanddelencategorieën (component material categories, CMCs, tabel 4.2). Nieuw is dat de verordening ook criteria stelt aan maximaal toelaatbare gehalten voor anorganische en organische contaminanten, pathogenen, ongewensten nevenbestanddelen (plastic, glas) en in de nabije toekomst aan de afbreekbaarheid van polymeren ${ }^{7}$.

\footnotetext{
${ }^{6}$ : CE staat voor Conformité Europenne. CE markering is de markering waarmee de fabrikant aangeeft dat het EU-bemestingsproduct in overeenstemming is met de toepasselijke eisen van de harmonisatiewetgeving van de Unie die voorziet in het aanbrengen ervan. De CE-markering is onderworpen aan de algemene beginselen die zijn vastgesteld in artikel 30 van Verordening (EG) nr. $765 / 2008$. Een bemestingsproduct dat voorzien is van een CE-markering wanneer het op de markt wordt aangeboden, wordt een EU-bemestingsproduct genoemd.

${ }^{7}$ Per 16 juli 2026 moeten polymeren die bij bepaalde gebruiksdoeleinden de productie van bemestingsproducten worden toegepast volledig biologisch afbreekbaar zijn.
} 
Tabel 4.1 Product functie categorieën (PFCS) van EU Verordening 2019/1009.

PFC Onderverdeling bemestingsproducten

1. Meststof
A. Organische meststof
I. Vaste organische meststof
II. Vloeibare organische meststof
B. Organo-minerale meststof
I. Vaste organo-minerale meststof
II. Vloeibare organo-minerale meststof
C. Anorganische meststof
I. Anorganische macronutriëntenmeststof

a) Vaste anorganische macronutriëntenmeststof

i) Enkelvoudige vaste anorganische macronutriëntenmeststof

A) Enkelvoudige vaste anorganische macronutriënten-meststof op basis van ammoniumnitraat en met een hoog stikstofgehalte

ii) Samengestelde vaste anorganische macronutriëntenmeststof

A) Samengestelde vaste anorganische macronutriëntenmeststof op basis van ammoniumnitraat en met een hoog stikstofgehalte

b) Vloeibare anorganische macronutriëntenmeststof

i) Enkelvoudige vloeibare anorganische macronutriënten-meststof

ii) Samengestelde vloeibare anorganische macronutriënten-meststof

II. Anorganische micronutriëntenmeststof

a) Enkelvoudige anorganische micronutriëntenmeststof

b) Samengestelde anorganische micronutriëntenmeststof

\title{
2. Kalkmeststof
}

3. Bodemverbeteraar

\author{
A. Organische bodemverbeteraar
}

B. Anorganische bodemverbeteraar

4. Groeimedium
5. Remmer
A. Nitrificatieremmer
B. Denitrificatieremmer
C. Ureaseremmer

6. Biostimulant voor planten

A. Microbiële biostimulant voor planten

B. Niet-microbiële biostimulant voor planten

7. Bemestingsproducten-blend 
Tabel 4.2 Bestanddelencategorieën (CMCS) van EU Verordening 2019/1009 en voorstellen (STRUBIAS) voor opname van nieuwe CMCs voor o.a. herwonnen fosfaten, verbrandingsassen en biochar.

CMC
1: Stoffen en mengsels als primair materiaal
CMC 2: Planten, delen van planten of plantenextracten
CMC 3: Compost
CMC 4: Digestaat van verse gewassen
CMC 5: Ander digestaat dan digestaat van verse gewassen
CMC 6: Bijproducten van de levensmiddelenindustrie
CMC 7: Micro-organismen
CMC 8: Nutriëntenpolymeren
CMC 9: Andere polymeren dan nutriëntenpolymeren
CMC 10: Afgeleide producten in de zin van Verordening (EG) nr. 1069/2009
CMC 11: Bijproducten in de zin van Richtlijn 2008/98/EG
(CMC 12: Precipitated phosphate salts \& derivates, STRUBIAS)
(CMC 13: Thermal oxidation materials \& derivates, STRUBIAS)
(CMC 14: Pyrolysis \& gasification materials, STRUBIAS )

De Europese Commissie heeft Joint Research Centre (JRC) een studie laten uitvoeren die tot doel heeft om o.a. herwonnen fosfaten, verbrandingsassen en biochar te gebruiken als grondstoffen bij de fabricage van bemestingsproducten (Huygens et al., 2019-I). De studie is bekend geworden onder de naam van de sub-werkgroep die JRC adviseerde (STRUBIAS (=STRviet BIochar AShes)). De Europese Commissie heeft de voorstellen ingebracht eind 2019 in de Fertiliser Expert Group (FEG). FEG bereidt vernieuwing en aanpassing van de nieuwe meststoffenverordening voor. In maart 2020 zou een vervolg plaatsvinden maar SARS-CoV-2 (Corona/CoVid-19) heeft de behandeling aangehouden. In tabel 4.2. zijn de CMCs toegevoegd. Hiervan hebben herwonnen fosfaten (precipitated phosphate salts \& deratives) een raakvlak met product 4 (mineraal P-product).

Conformiteitsbeoordeling ${ }^{8}$ in het kader van EU verordening 2019/1009 kent een andere aanpak dan in EU 2003/2003. De aangewezen nationale autoriteit van een lidstaat ziet toe op de aanwijzing en aanmelding van conformiteitsbeoordelingsinstanties en voert markttoezicht uit. Alle overige handelingen in het kader van conformiteitsbeoordeling is aan fabrikant en/of conformiteitsbeoordeling uitvoerende instanties (bv. KIWA) afhankelijk van de module ( $A, A 1, B, C$ en D).

Markttoezichthouders bewaken de niet-conformiteit. Dat kan via gerichte monstername en/of door het opvragen van gegevens over de conformiteitsbeoordeling bij de marktdeelnemer (veelal de fabrikant). Aan bemestingsproducten (PFC) en hun grondstoffen (CMC) worden eisen gesteld aan de kwaliteit (bijlage I en bijlage II).

Afvalstoffen die beantwoorden aan eisen gesteld aan PFC en die een CE-markering voeren bereiken daardoor een einde-afval-status (End-of-Waste). De afvalstof wordt dan niet meer geclassificeerd als afvalstof, het heeft dan de wettelijke status van product. EVOA ${ }^{9}$ bepalingen zijn dan niet meer van toepassing. Een CMC kan niet een einde-afval-status verkrijgen.

Kwaliteitscriteria kunnen vastgesteld worden door geharmoniseerde standaarden van analysemethoden. CEN zal een mandaat van COM krijgen om deze standaarden aan te wijzen (circa 370 standaarden ondergebracht in 68 koepelnormen. Bij het schrijven van dit hoofdstuk (maart 2020) was het mandaat nog niet door CEN geaccepteerd. De Europese Commissie heeft aangegeven dat deze standaarden facultatief zijn. Of dat mogelijk is in het kader van handhaving op verontreinigende stoffen, pathogenen en andere ongewenste nevenbestanddelen (glas, plastic), wordt betwijfeld. Het ligt voor de hand om bij grensoverschrijdend handelsverkeer van bemestingsproducten de EU Verordening te volgen maar noodzakelijk is dat zeker niet. In het verleden opgebouwde bilaterale contacten en daarbij horende afspraken passend bij nationale wet- en regelgeving kunnen gecontinueerd worden.

\footnotetext{
${ }^{8}$ Conformiteitsbeoordeling is het proces waarin wordt aangetoond of al dan niet voldaan is aan de eisen van de EU Verordening 2019/1009 voor een EU-bemestingsproduct. Conformiteitsbeoordeling is een gestructureerd proces met benoemde rolverdeling tussen de nationale autoriteit, de aanmeldende autoriteit en de aangemelde instanties. In de uitvoeringspraktijk wordt conformiteitsbeoordeling uitgevoerd door de fabrikant of een aangewezen (aangemelde) instantie (bv. KIWA).

${ }^{9}$ Europese Verordening Overbrenging Afvalstoffen (EVOA), Verordening (EG) Nr. 1013/2006
} 
In beginsel kunnen alle hier beschouwde producten in het vrijhandelsverkeer gebracht worden onder de bepalingen van de nieuwe Europese Meststoffenverordening (2019/1009). Voorwaarde hiervoor is dat de producten uit mestverwaarding dan voldoen aan de eisen van CMC 10 Afgeleide producten in de zin van verordening EG nr. 1069/2009 (waarvan de eisen nog niet zijn geformuleerd). Dit is dan ook nog onzeker.

\subsubsection{Nitraatrichtlijn en JRCs project Safemanure}

De Nitraatrichtlijn (91/676/EEC)) heeft tot doel de waterkwaliteit in Europa te beschermen door te voorkomen dat nitraten het grond- en oppervlaktewater verontreinigen. Daartoe wordt het gebruik van stikstofhoudende bemestingsproducten gereguleerd. Eén van de bepalingen is dat de gift aan dierlijke mest niet hoger mag zijn dan $170 \mathrm{~kg} \mathrm{~N} / \mathrm{ha} /$ jaar. Een hogere stikstofgift met (producten uit) dierlijke mest vraagt een ontheffing (derogatie).

De Nitraatrichtlijn geeft voor de uitvoering van deze bepaling een begripsomschrijving van dierlijke mest (artikel 2g):

"dierlijke mest": excrementen van vee of een mengsel van strooisel en excrementen van vee, alsook producten daarvan;

Door artikel $2 \mathrm{~g}$ van de Nitraatrichtlijn zijn alle PMCs die stikstof bevatten geclassificeerd als dierlijke mest en hun gebruik valt daardoor onder de gebruiksbepalingen van de Nitraatrichtlijn voor dierlijke mest. Dit geldt ook voor bemestingsproducten zoals ammoniumsulfaat van strippers en mineralenconcentraat. Dit wordt al jaar en dag als knellend bestempeld. De Europese Commissie erkent dit en heeft actie ondernomen om ervoor te zorgen dat de vernieuwde technologische en marktontwikkelingen voor de recycling van nutriënten in een circulaire economie afgestemd kunnen worden met de doelstelling om waterlichamen te beschermen tegen vervuiling afkomstig van dierlijke mest. Daarvoor is aan JRC de opdracht gegeven om criteria af te leiden voor stikstofhoudende bemestingsproducten geheel of gedeeltelijk van dierlijke mest die gebruikt kunnen worden volgens dezelfde bepalingen als stikstof van minerale meststoffen (chemische meststof). JRC heeft deze bemestingsproducten aangeduid als RENURE (REcovered Nitrogen from MANure).

Op 18 november 2019 heeft JRC een interimrapport opgeleverd. Dit interimrapport is van 28 tot en met 30 januari 2020 besproken tijdens een Stakeholders Workshop bij JRC te Sevilla. In mei levert JRC haar eindrapport op. In juni is het rapport door de Europese Commissie geagendeerd in de Nitrates Expert Group en start het proces van beleidsontwikkeling en -afweging. De stand van zaken rond RENURE na afloop van de stakeholderworkshop (dd. 31 januari 2020) is de volgende:

\section{RENURE materials: Any $N$ containing substance fully or partially derived from livestock} manure through processing under controlled conditions that can be used in areas with water pollution by $N$ following the same provisions applied to $N$ containing chemical fertilisers as defined in the Nitrates Directive (91/676/EEC), while providing adequate agronomic benefits to enhance plant growth.

2. RENURE bemestingsproducten moeten tenminste $(\geq) 90 \%$ minerale stikstof t.o.v. stikstof totaal bevatten $\underline{\mathrm{OF}}$ de verhouding organische koolstof t.o.v. stikstof totaal moet kleiner of gelijk ( $\leq$ ) zijn aan 3. Deze verhoudingen moeten gecorrigeerd worden voor elke toevoeging van chemische stikstof afkomstig van Haber-Bosch-proces.

3. RENURE bemestingsproducten mogen de volgende limieten aan zware metalen niet overschrijden:
a. Koper: $300 \mathrm{mg} / \mathrm{kg}$ droge stof
b. Kwik: $1 \mathrm{mg} / \mathrm{kg}$ droge stof
C. Zink: $800 \mathrm{mg} / \mathrm{kg}$ droge stof

4. Lidstaten moeten de nodige voorzieningen treffen om ervoor te zorgen dat het tijdstip van toediening en de gift van RENURE en andere materialen worden gesynchroniseerd met de NPK-behoefte van de gewassen om uit- en afspoeling van nutriënten te voorkomen en tot een minimum te beperken, bv. door het gebruik van vanggewassen, indien van toepassing. 
5. Lidstaten moeten de nodige voorzieningen treffen om NH3-emissies te voorkomen en te minimaliseren tijdens RENURE toepassing op het veld (JRC zal bezien of onderdelen $a$ en $b$ kunnen vervallen):

a. Bemestingsproducten met minder dan (<) $40 \%$ nitraat t.o.v. totaal stikstof.

b. Voor producten met een bepaalde zuurgraad. Oorspronkelijk was het criterium pH$\mathrm{H}_{2} \mathrm{O}$ bodem $>5$. JRC zal onderzoeken of de $\mathrm{pH}$ van het product een betere beheersing van het risico op ammoniak vervluchtiging geeft.

6. Lidstaten moeten maatregelen nemen om emissies naar de lucht tijdens de opslag van RENURE bemestingsproducten te voorkomen en te minimaliseren. Emissies zijn verbonden aan ammoniak en broeikasgassen. JRC beziet of dit criterium met het criterium over ammoniak emissie geïntegreerd kan worden.

7. Nieuw criterium: informatie over de samenstelling van $\mathrm{N}, \mathrm{P}$ en $\mathrm{K}$ moet worden verstrekt om een juiste toepassing en gebruik van RENURE-materiaal te bevorderen.

Stakeholders hebben wijzigingen voorgesteld bij deze criteria. Bij criterium 1 (hiervoor genoemd onder punt 2) zou OF vervangen kunnen worden door EN waardoor mineralenconcentraat geen RENURE materiaal meer is. JRC heeft dit niet overgenomen. Door DG-ENVI werd aangegeven dat naast beheersing van stikstof uit- en afspoeling ook de beheersing van gasvormige emissies sturend zal zijn. Die sturing wordt aan de lidstaten overgelaten. Het criterium voor de $\mathrm{pH}$ wordt waarschijnlijk verbonden aan het bemestingsproduct en niet aan grond.

Criteria worden niet gekoppeld aan een productieproces maar mest moet wel een vorm van bewerking hebben ondergaan. Een begripsomschrijving van bewerking van mest is opgesteld maar zal door JRC worden herzien.

\subsection{Nationale wet- en regelgeving}

Elke lidstaat heeft naast regulering volgens de huidige Europese meststoffenverordening eigen nationale regelgeving voor andere meststoffen. De nationale wet- en regelgeving blijft bestaan ook na publicatie van de nieuwe Europese meststoffenverordening (EC/2019/1009). Na publicatie van de verordening zijn de lidstaten aan de slag gegaan om de verordening te implementeren. Dit proces zal naar verwachting afgerond zijn op 16 juli 2022 omdat dan de EG Verordening 2003/2003 wordt ingetrokken. In de regel trachten lidstaten bij implementatie hun nationale wet- en regelgeving zoveel mogelijk ongewijzigd voort te zetten.

\subsubsection{Nederland}

De Nederlandse Meststoffenwet ${ }^{10}$ dient twee doelen. De Meststoffenwet reguleert de vrije verhandeling van meststoffen. Het belangrijkste en tweede doel van de Meststoffenwet is de regulering van het mestoverschot. Bij regulering van het mestoverschot is het gebruik van dierlijke mest en producten daarvan afgestemd met bepalingen van de Wet Milieubeheer en in het bijzonder de daaronder ressorterende Wet Bodembescherming. Regulering van het mestoverschot komt voort uit verplichtingen opgelegd door de Nitraatrichtlijn ${ }^{11}$.

De Meststoffenwet (MW) is uitgewerkt in een uitvoeringsbesluit (UBMW) en een uitvoeringsregeling (URMW). De nieuwe EU Verordening (2019/1009) wordt geïmplementeerd in MW, UBMW en URMW. Het gebruik van RENURE producten vergt afstemming met de Wet Bodembescherming en het daaronder ressorterende Besluit Gebruik Meststoffen hetgeen pas uitvoering kan krijgen nadat RENURE criteria geïmplementeerd zijn op Europees niveau in de Nitraatrichtlijn.

De Nederlandse Meststoffenwet werd in 2008 ingrijpend gewijzigd bij opname van bepaling voor vrijhandelsverkeer voor meststoffen in de Meststoffenwet onder intrekking van de Meststoffenwet 1947. Een ingrijpende wijziging is het vervallen van positieve lijsten met typeaanduidingen voor

\footnotetext{
${ }^{10}$ Meststoffenwet: https://wetten.overheid.nl/BWBR0004054/2020-02-20

11 Richtlijn van de Raad inzake de bescherming van water tegen verontreiniging van nitraten uit agrarische bronnen, 91/676/EEG.
} 
bemestingsproducten die niet voldeden aan bepalingen voor het voeren van het EG-label. Alleen het begrip meststof wordt vanaf 2008 gevoerd waarbij alleen 'overige anorganische meststof' en 'overige organische meststof' nog worden onderscheiden. De duiding 'overig' dient ter onderscheid t.o.v. van respectievelijk EG-meststoffen (minerale meststof, kalkmeststof) en t.o.v. dierlijke mest, compost en zuiveringsslib waarvoor andere criteria gelden. De MW laat wettelijke bepalingen voor dierlijke bijproducten (EU/1069/2009 en EU/2011/142) onverlet d.w.z. dat sanitatieverplichtingen voor dierlijke bijproducten niet expliciet in de MW zijn opgenomen. Bemestingsproducten van dierlijke mest dienen te beantwoorden aan EU/1069/2009 en EU/142/2011) d.w.z. dat het eindpunt van deze regelgeving bereikt moet zijn.

In Nederland is het proces gestart met het aanwijzen van de bevoegde nationale autoriteit. Bij conformiteitsbeoordeling van EU-bemestingsproducten worden om een consistent kwaliteitsniveau te waarborgen, ook voorschriften gegeven voor de aanmeldende autoriteiten en voor andere instanties die bij de beoordeling en aanmelding van en het toezicht op aangemelde instanties betrokken zijn. De implementatie is gestart met het invullen van dit nieuwe wettelijke kader en het benoemen van betrokken actoren. Als beeldvorming: de bevoegde nationale autoriteit zou de NVWA kunnen zijn, het toezicht op aangemelde en beoordelende instanties zou uitgevoerd kunnen worden door de Raad van Accreditatie. Aangemelde en beoordelende instanties zijn er nog niet; KIWA heeft belangstelling getoond.

In beginsel kunnen de hier beschouwde producten in de zeer nabije toekomst (vanaf 17 juli 2022) onder bepalingen van EU Verordening 2019/1009 in het vrij handelsverkeer gebracht worden zowel in Nederland als in andere lidstaten van EU27. In de huidige situatie zijn de mogelijkheden voor het gebruik van de $\mathrm{N}$-producten in Nederland enigszins beperkt omdat ze de status hebben van dierlijke mest waardoor ze vallen onder de gebruiksnormen voor dierlijke mest.

Meststoffenwet, artikel 1 c. dierlijke meststoffen: uitwerpselen van voor gebruiks- of winstdoeleinden gehouden dieren, daaronder begrepen de geheel of gedeeltelijk verteerde maag- of darminhoud van deze dieren en mengsels van strooisel met de uitwerpselen, alsook producten daarvan;

De stikstofhoudende bemestingsproducten kunnen daardoor weliswaar in Nederland vrij verhandeld worden, maar hebben de status van dierlijke mest. Spuiwater is daar een uitzondering op. Spuiwater is opgenomen in bijlage Aa van de Uitvoeringsregeling Meststoffenwet (URMW) ${ }^{12}$. De N-gehalten zijn doorgaans lager dan $5 \%$ en beantwoorden in regel niet aan criteria voor PFC's (zie volgende hoofdstuk).

12 Uitvoeringsregeling Meststoffenwet, bijlage Aa: https://wetten.overheid.nl/BWBR0018989/2020-01-01

Bijlage Aa: bijlage Aa. behorende bij artikel 4 van de Uitvoeringsregeling Meststoffenwet https://wetten.overheid.nl/BWBR0018989/2020-01-01\#BijlageAa I. Stoffen die als meststof kunnen worden verhandeld.

9. Reststof die is vrijgekomen bij de chemische reiniging van lucht uit een bedrijfshal, waar (gecomposteerd) zuiveringsslib met houtsnippers wordt gecomposteerd door middel van het wassen met een verdunde waterige oplossing van zwavelzuur en die bestaat uit een $\mathrm{pH}$-neutrale oplossing van ammoniumsulfaat in water (ammoniumsulfaathoudende spuiwater van chemische luchtwassers van composteerhallen).

22. Reststof die is vrijgekomen bij de chemische reiniging van lucht uit een bedrijfshal met tunnels waarin pluimveemest wordt gecomposteerd, gedroogd en gepelleteerd, door middel van het wassen met een verdunde waterige oplossing van zwavelzuur en die bestaat uit een zure oplossing van ammoniumsulfaat in water (ammoniumsulfaathoudend spuiwater van chemische luchtwassers van mestkorrelinstallaties voor pluimveemest).

II. Stoffen die als meststof kunnen worden verhandeld (Categorieën afvalstoffen of reststoffen)

1. Reststof die is vrijgekomen bij de chemische reiniging van stallucht van veehouderijbedrijven door het wassen van de stallucht met ammoniak in een verdunde oplossing van zwavelzuur en die bestaat uit een ammoniumsulfaatoplossing in water (spuiwater uit luchtwassers met een chemische wasstap).

2. Reststof die is vrijgekomen bij de biologische reiniging van stallucht van veehouderijbedrijven door het wassen van stallucht met water en geleid over materiaal met een ruimtelijke structuur waarop nitrificerende bacteriën ammonium omzetten in nitriet en vervolgens in nitraat en die bestaat uit een zeer sterk verdunde $\mathrm{pH}$-neutrale zwavel- en stikstofhoudende oplossing in water (spuiwater luchtwassers met een biologische wasstap).

3. Reststof die is vrijgekomen bij de reiniging van stallucht van veehouderijbedrijven door het wassen van stallucht met water (spuiwater uit luchtwassers met een waterwasstap). 
Ook de fosfaathoudende PMCs hebben nog geen plek in de Nederlandse Meststoffenwet t.a.v. vrij handelsverkeer. Weliswaar zijn herwonnen fosfaten opgenomen in het Uitvoeringsbesluit Meststoffenwet, echter de begripsomschrijving sluit fosfaat van dierlijke mest uit ${ }^{13}$. De nieuw Europese meststoffenverordening (EU/2019/1009) kan hier verandering in brengen nadat CMC 10 opgesteld is (in het bijzonder de criteria voor verwerkte dierlijke mest) en in het bijzonder na opname van een nieuwe CMC categorie (CMC XX: Precipitated phosphate salts \& derivates, STRUBIAS).

In beginsel zou een product dat louter uit kali bestaat, kunnen ressorteren onder de begripsaanduiding van overige anorganische meststof ${ }^{14}$ van het UBMW mits het bemestingsproduct geen stikstof bevat.

Als overige anorganische meststoffen dient het bemestingsproduct ten minste $5 \%$ wateroplosbare kali $\left(\mathrm{K}_{2} \mathrm{O}\right)$ in de drogestof te bevatten en mogen de milieucriteria gegeven in bijlage $\mathrm{II}^{15}$ van het Uitvoeringsbesluit niet overschreden worden.

Paragraaf 4.3. geeft een overzicht van de eisen aan bemestingsproducten van de PMCs.

\subsubsection{Duitsland}

In Duitsland zijn de volgende wetten bepalend voor de verhandeling en gebruik in Duitsland van bemestingsproducten met dierlijke mest:

- $\quad$ De kaderwet Düngegesetz (DüG ${ }^{16}$ )

- $\quad$ De kwaliteit wordt gereguleerd door Düngemittelverordnung (DüMV ${ }^{17}$ )

- $\quad$ Het gebruik wordt gereguleerd door Düngeverordnung (DÜV ${ }^{18}$ )

- $\quad$ Specifieke bepalingen voor dierlijke mest worden gereguleerd door Verordnung über das Inverkehrbringen und Beförderen von Wirtschafsdünger (WDüngV ${ }^{19}$ )

In de laatste 8 jaar zijn diverse grote wijzigingen aangebracht in deze wetten. Belangrijke wijzigingen zijn geweest de overgang van negatieve lijsten naar positieve lijsten voor bemestingsproducten in 2012 en in 2017 criteria voor beheersing van risico's op milieubezwaarlijkheid en aanscherping van gebruiksbepalingen voor organische bemestingsproducten t.b.v. het voldoen aan de bepalingen van de Nitraatrichtlijn.

Duitse regelgeving voor bemestingsproducten kent meer uitwerking in detail dan de Nederlandse regelgeving doordat o.a. met positieve lijsten met op bemestingsproduct afgestemde regelgeving.

Düngegesetz (DüG) is de kaderwet die regulering geeft aan doel, werkingssfeer, begripsomschrijvingen, afstemming met de Nitraatrichtlijn, vrij handelsverkeer van meststoffen, EG-meststoffen, typeaanduiding, verpakking, toleranties, monstername en analysemethoden, wetenschappelijk

${ }^{13}$ Uitvoeringsbesluit Meststoffenwet: https://wetten.overheid.nl/BWBR0019031/2020-01-01

Artikel 1. aa. herwonnen fosfaten:

$1^{\circ}$. struviet, hoofdzakelijk bestaand uit magnesiumammoniumfosfaat, dat is vrijgekomen bij de zuivering van industrieel proceswater of huishoudelijk, stedelijk of industrieel afvalwater dan wel ander afvalwater door precipitatie met opgelost magnesium, ammonium of kalium;

$2^{\circ}$. magnesiumfosfaat, dat is vrijgekomen bij pasteurisatie of bij het drogen van struviet, of

$3^{\circ}$. dicalciumfosfaat, hoofdzakelijk bestaand uit dicalciumfosfaat, dat is vrijgekomen bij de zuivering van huishoudelijk, stedelijk of industrieel afvalwater dan wel ander afvalwater door precipitatie met opgelost calcium.

${ }^{14}$ Uitvoeringsbesluit Meststoffenwet, artikel 1.1.j. overige anorganische meststoffen: anorganische meststoffen niet zijnde EG-meststoffen of herwonnen fosfaten;

${ }^{15}$ Uitvoeringsbesluit Meststoffenwet, bijlage II: https://wetten.overheid.nl/BWBR0019031/2020-01$01 \#$ BijlageII

${ }^{16}$ https://www.gesetze-im-internet.de/d ngg/

${ }^{17}$ https://www.gesetze-im-internet.de/d mv 2012/index.html

${ }_{18}^{18}$ https://www.gesetze-im-internet.de/d v 2017/index.html

${ }^{19}$ https://www.gesetze-im-internet.de/wd ngv/index.html 
advisering, bestuursrechtelijke aspecten en administratieve aspecten. Regulering verloopt via specifiekere maar toch ook generiekere bepalingen. DüG geeft uitvoering aan EG Verordening 2003/2003. De uitwerking van deze gestelde kaders vindt o.a. plaats in DüMV, DüV en WDüngV. Voor vrijhandelsverkeer is DüMV relevant.

Düngemittelverordnung (DüMV) reguleert meststoffen die niet het 'EG-label' kunnen voeren niet generiek, zoals MW, maar per product. Dat leidt tot meer bepalingen. DüMV regelt dit via bepalingen voor de typeaanduiding van meststoffen, minimumgehalte voor nutriënten van de meststof met hun oplosbaarheid in aangewezen extractiemiddelen, herkomst en productieprocedé, fysische eigenschappen, gehalten aan nevenbestanddelen, andere voor de landbouwkundige werkzaamheid of het gebruik van meststoffen belangrijke kenmerken, sanitatieverplichtingen, toleranties en sancties.

DüMV reguleert meststoffen, bodemverbeterende middelen, bodemhulpstoffen, groeimedia en plantenhulpstoffen. Voor ieder van deze producten is een typeaanduiding met begripsomschrijving, eisen en specifieke voorwaarden opgesteld. Specifieke voorwaarden zijn er voor verplichtingen voor sanitatie en maximumeisen voor aangewezen contaminanten. Ook worden regels gesteld uit welke grondstoffen of afval- en reststoffen meststoffen geproduceerd mogen worden.

Bij vrijhandelsverkeer dient elk bemestingsproduct en elke partij voorzien te zijn van een document met een declaratie van de waardegevende bestanddelen (Warendeklaration ${ }^{20}$ ). De Warendeklaration is niet gelijk aan de afleveringsbon (Lieferscheinverfahren) dat de Bundesverbringensverordnung für Wirtschaftsdünger (WDüngV) ${ }^{21}$ oplegt. Daarnaast geldt er een meldingsplicht bij de deelstaat. In de uitvoeringspraktijk wil de Warendeklaration nog wel eens verward worden met de afleveringsbon hetgeen kan leiden tot boetes.

Een Warendeklaration vermeldt (zie §6 DüMV):

- Typenaanduiding (Typenbezeichnung): Bij mest bv. vloeibaar (drogestof gehalte (DS) $<15 \%$ ), vast (DS>15\%), dierlijk bijproduct, diersoort.

- Nutriënten: Totaal stikstof, stikstof van dierlijke herkomst (ivm Nitraatrichtlijn), gewas beschikbaar stikstof (stikstof $\mathrm{CaCl}_{2}$ oplosbaar mits hoger dan $10 \%$ ), totaal fosfaat, totaal kali $\left(\mathrm{K}_{2} \mathrm{O}\right)$ in de waar als zodanig (productbasis). Daarnaast worden secundaire en spoorelementen aangewezen.

- Producent, handelshuis, naam en volledig adres. Als producent en handelshuis niet dezelfde rechtspersoon zijn, dan dienen beiden genoemd te worden.

- Grond- en hulpstoffen en nevenbestanddelen (organische stof, zwavel etc.)

- Instructie voor opslag en toediening.

Een overzicht van de eisen voor de PMCs wordt gegeven in bijlage 4.

\footnotetext{
${ }^{20}$ zie paragraaf 4 van DüMV en bijlage 2 , tabellen 6 - 8 en tabel 1.4 (lid 4 en 5).

${ }^{21}$ https://www.gesetze-im-internet.de/wd_ngv/BJNR106200010.html
} 


\section{$5 \quad$ Toetsing van producten aan Europese wetgeving}

In dit hoofdstuk worden de bepalingen van de Europese wet- en regelgeving per product en de beoogde afzetmarkt beschreven. Dit betreft een momentopname (maart 2020). Regelgeving voor vrijhandelsverkeer van meststoffen en het gebruik van stikstofhoudende bemestingsproducten gebaseerd op dierlijke mest maken thans een ontwikkeling door die nog niet een eindfase bereikt hebben.

Bij EU Verordening 2019/1009 heeft DG Sancto voor verwerkte mest nog geen aanwijzing gegeven hoe CMC 10 ingevuld gaan worden. In deze paragraaf wordt ervan uitgegaan dat het eindpunt voor verwerkte mest niet zal verschillen dan die welke nu al gelden voor dierlijke mest in kader van de Europese regelgeving voor dierlijke bijproducten (EU/1069/2009 en EU/142/2011). Verondersteld wordt daardoor dat het eindpunt bereikt is als een bemestingsproduct van dierlijke mest gesaniteerd is.

Voor de RENURE criteria geldt dat hierover nog geen definitieve Europees beleidsvorming heeft plaatsgevonden. Het betreffen indicatieve criteria gebaseerd op het interim rapport van JRC. EU Verordening 2019/1009 moet nog geïmplementeerd worden. De gevolgen voor de huidige Nederlandse meststoffenwet en die voor de beoogde exportregio's zijn nog niet aan te geven. In de hierna volgende paragrafen wordt de volgende informatie per product beschreven:

- Samenstelling van waardegevende bestanddelen (drogestof, organische stof en macronutriënten) van het product op basis waarvan het wordt beoordeeld;

- Beoordeling aan de hand van EU verordening 2019/1009 en toetsing aan de criteria, inclusief die voor zware metalen;

- $\quad$ Beoordeling of product voldoet aan RENURE criteria;

- Toetsing aan relevante nationale wetgeving.

\subsection{Mineraal N-product (5\%) Nederland, Duitsland en Frankrijk}

Zoals in hoofdstuk 2 is aangegeven betreft het hier een mineraal $\mathrm{N}$-product met $5 \% \mathrm{~N}$ dat is gemaakt door het strippen met zwavelzuur $\left(\mathrm{H}_{2} \mathrm{SO}_{4}\right)$, waardoor een ammoniumsulfaat-oplossing $\left(\left(\mathrm{NH}_{4}\right)_{2} \mathrm{SO}_{4}\right)$ ontstaat. De gehalten aan drogestof, organische stof en macronutriënten in het product zijn opgenomen in Tabel 5.1.

Tabel 5.1 Samenstelling mineraal N-product (5\%), in \%.

\begin{tabular}{|c|c|c|c|c|c|c|c|c|c|c|}
\hline Product & DS & os & N-tot & $\mathrm{NH}_{4}-\mathrm{N}$ & $\mathrm{NO}_{3}-\mathrm{N}$ & N-org & $\mathrm{P}_{2} \mathrm{O}_{5}$ & $\mathrm{~K}_{2} \mathrm{O}$ & $\mathrm{SO}_{3}$ & $\mathrm{MgO}$ \\
\hline
\end{tabular}

Zoals in het voorgaande hoofdstuk (paragraaf 4.1.2) is beschreven, worden in de nieuwe Europese meststoffenverordening 2019/1009 7 productfunctiecategorieën (PFC's) onderscheiden (Tabel 4.1). In de publicatie van EU 2019/1009 (EU, 2019) worden de criteria beschreven op basis waarvan kan worden beoordeeld of een product in een bepaalde PFC past. Het mineraal N-product kan op basis van de samenstelling in tabel 5.1 worden ingedeeld in PFC 1 C) I) b) i) Enkelvoudige vloeibare anorganische macronutriëntenmeststof. Eisen die aan dit product worden gesteld zijn als volgt:

- Het product is een meststof die nutriënten in een minerale vorm bevat of afgeeft en die geen organische of organo-minerale meststof is (eis anorganische meststof);

- Als het product meer dan $1 \%$ C-organisch bevat, zijn er eisen aan het maximaal aantal pathogenen in het product. Zo mag geen Salmonella worden aangetroffen in $25 \mathrm{~g}$ of $25 \mathrm{ml}$ van het product en dient het aantal organismen van Escherichia coli of Enterococcae niet 
meer te zijn dan 1000 in $1 \mathrm{~g}$ of $1 \mathrm{ml}$ van het product (eis anorganische meststof). Aangezien het de verwachting is dat het product geen C-organisch bevat, is deze eis niet relevant;

- Het product heeft tot doel planten van één of meer primaire of secundaire macronutriënten te voorzien (eis anorganische macronutriëntenmeststof). Product bevat $\mathrm{N}$ en $\mathrm{S}$;

- De grenswaarden voor zware metalengehalten (Tabel 5.2) mogen niet worden overschreden (eis anorganische macronutriëntenmeststof). Aangenomen wordt dat de hoeveelheid zware metalen die door het stripproces in het product terecht komen zeer klein is en dat de gehalten verwaarloosbaar zijn.

Tabel 5.2 Normen voor zware metalen in EU verordening 2019/1009 (voor PFC anorganische macronutriëntmeststoffen met $<5 \% \mathrm{P}_{2} \mathrm{O}_{5}$ ).

\begin{tabular}{|c|c|c|c|c|c|c|c|c|}
\hline \multirow[t]{2}{*}{ Product } & \multicolumn{8}{|c|}{ gehalten aan zware metalen in mg/kg ds } \\
\hline & As & Cd & $\mathrm{Cr}$ VI & $\mathrm{Cu}$ & $\mathrm{Hg}$ & Ni & $\mathrm{Pb}$ & $\mathrm{Zn}$ \\
\hline EU-norm anorganische macronutriëntmeststof & 40 & 3 & 2 & 600 & 1 & 100 & 120 & 1500 \\
\hline
\end{tabular}

- Het product heeft een vloeibare vorm (eis vloeibare anorganische macronutriëntenmeststof);

- Het product bevat slechts één primair macronutriënt en één of meer secundaire macronutriënten (eis enkelvoudige, vloeibare anorganische macronutriëntenmeststof). Product bevat $\mathrm{N}$ en $\mathrm{S}$.

- $\quad$ Aangezien het product uitsluitend $\mathrm{N}$ en $\mathrm{S}$ bevat, dient het $\mathrm{N}$-gehalte ten minste $1,5 \% \mathrm{~N}$ te zijn en het S-gehalte minimaal $0,75 \% \mathrm{SO}_{3}$ (eis enkelvoudige, vloeibare anorganische macronutriëntenmeststof). Uit tabel 5.1 blijkt dat het product hieraan voldoet.

Naast de beoordeling of het product CE-waardig is in het kader van de nieuwe EU Meststoffenverordening 2019/1009, is het van belang hoe er vanuit de EU Nitraatrichtlijn (91/676/EEC) tegen het product wordt aangekeken (zie tabel 5.3 samenvatting beoordeling). Zoals in paragraaf 4.1.3 is aangegeven worden stikstofhoudende meststofproducten die uit dierlijke mest worden vervaardigd in principe geclassificeerd als dierlijke mest, waardoor ze vallen onder de gebruiksbepalingen van de Nitraatrichtlijn voor dierlijke mest. Dit betekent dat de maximale gift met dat en andere producten uit dierlijke mest $170 \mathrm{~kg} \mathrm{~N} / \mathrm{ha} / \mathrm{jaar}$ bedraagt. In het project Safemanure is door het Joint Research Centre (JRC) onderzocht onder welke criteria stikstofhoudende bemestingsproducten uit dierlijke mest volgens dezelfde bepalingen gebruikt kunnen worden als stikstof van gangbare minerale meststoffen (kunstmest). De betreffende producten zijn aangeduid als Recovered Nitrogen from MANure (RENURE). Er is in september 2019 een concept-rapport uitgebracht waarin de criteria zijn beschreven (Huygens et al., 2019-II), maar deze zijn dus nog onder voorbehoud. Een belangrijk criterium is dat het $\mathrm{N}$-mineraal-gehalte van $\mathrm{N}$-totaal minimaal $90 \%$ bedraagt. Daarnaast zijn er grenswaarden voor de gehalten aan de zware metalen koper (Cu), kwik $(\mathrm{Hg})$ en zink $(\mathrm{Zn})$ geformuleerd ( $\mathrm{Cu}<300 \mathrm{mg} / \mathrm{kg}$ ds, $\mathrm{Hg}<1 \mathrm{mg} / \mathrm{kg}$ ds en $\mathrm{Zn}<800 \mathrm{mg} / \mathrm{kg} \mathrm{ds})$. Het mineraal N-product ( $5 \%$ ) voldoet aan de RENURE-criteria, wat betekent dat de $\mathrm{N}$-gift met dit product in de toekomst niet gebonden is aan het maximum van $170 \mathrm{~kg} \mathrm{~N} / \mathrm{ha}$ uit de Nitraatrichtlijn. 
Tabel 5.3 Beoordeling product op basis van Europese en nationale eisen aan een mineraal $N$-product (5\%).

\begin{tabular}{|c|c|c|c|}
\hline EG Verordening 2003/2003 & EU Verordening 2019/1009 & $\begin{array}{l}\text { Nitraatrichtlijn } \\
\text { RENURE criteria in } \\
\text { voorbereiding }\end{array}$ & $\begin{array}{l}\text { Nederlandse } \\
\text { meststoffenwet }\end{array}$ \\
\hline $\begin{array}{l}\text { Geen mogelijkheid om EG-label te voeren. } \\
\text { Stikstofgehalte is te laag om te kunnen } \\
\text { beantwoorden aan Bijlage } 1 . \mathrm{C} \text {. } \\
\text { Anorganische vloeibare meststoffen } \\
\text { C.1. Enkelvoudige vloeibare meststoffen nr. } \\
1 \text { Oplossing van stikstofmeststoffen. }\end{array}$ & $\begin{array}{l}\text { Als er meer dan } 1 \% \\
\text { Corganisch aanwezig is, zijn } \\
\text { eisen t.a.v. pathogenen van } \\
\text { toepassing. Dit is } \\
\text { waarschijnlijk niet het geval. } \\
\text { De eisen voor zware metalen } \\
\text { knellen waarschijnlijk niet. }\end{array}$ & $\begin{array}{l}\text { De eisen voor zware } \\
\text { metalen knellen } \\
\text { waarschijnlijk niet. }\end{array}$ & $\begin{array}{l}\text { Product valt onder de } \\
\text { begripsomschrijving } \\
\text { van dierlijke mest en } \\
\text { daardoor onder de } \\
\text { gebruiksbepalingen } \\
\text { van dierlijke mest. } \\
\text { Uitzondering vormt } \\
\text { spuiwater. Spuiwater } \\
\text { opgenomen in bijlage } \\
\text { Aa van de URMW kan } \\
\text { regulier verhandeld } \\
\text { worden. }\end{array}$ \\
\hline
\end{tabular}

\subsection{Mineraal N-product (15-20\%) Nederland, Duitsland, Frankrijk en overig}

Zoals in hoofdstuk 2 is aangegeven betreft het hier een mineraal $\mathrm{N}$-product met $15-20 \% \mathrm{~N}$ dat is gemaakt door het strippen met salpeterzuur $\left(\mathrm{HNO}_{3}\right)$, waardoor een ammoniumnitraat-oplossing $\left(\mathrm{NH}_{4} \mathrm{NO}_{3}\right)$ ontstaat. Aangezien ammoniumnitraat tevens kan worden gebruikt als basis voor explosieven, worden er nogal wat veiligheidseisen gesteld aan de productie, het opslag en gebruik. Bij het ontwikkelen van plannen voor de productie van ammoniumnitraat moet dit nader worden verkend. De gehalten aan drogestof, organische stof en macronutriënten in het product zijn opgenomen in Tabel 5.4.

Tabel 5.4 Samenstelling mineraal N-product (15-20\%), in \%.

\begin{tabular}{|c|c|c|c|c|c|c|c|c|c|c|}
\hline Product & DS & os & N-tot & $\mathrm{NH}_{4}-\mathrm{N}$ & $\mathrm{NO}_{3}-\mathrm{N}$ & $\mathrm{N}$-org & $\mathrm{P}_{2} \mathrm{O}_{5}$ & $\mathrm{~K}_{2} \mathrm{O}$ & $\mathrm{SO}_{3}$ & $\mathrm{MgO}$ \\
\hline Mineraal N-product (15-20\%) & 50,0 & & 17,5 & 8,8 & 8,8 & & & & & \\
\hline
\end{tabular}

Het mineraal $\mathrm{N}$-product met $15-20 \% \mathrm{~N}$ kan evenals het mineraal $\mathrm{N}$-product met $5 \% \mathrm{~N}$ op basis van de samenstelling in tabel 5.4 worden ingedeeld in PFC 1 C) I) b) i) Enkelvoudige vloeibare anorganische macronutriëntenmeststof. Eisen die aan dit product worden gesteld zijn als volgt:

- Het product is een meststof die nutriënten in een minerale vorm bevat of afgeeft en die geen organische of organo-minerale meststof is (eis anorganische meststof);

- Als het product meer dan 1\% C-organisch bevat, zijn er eisen aan het maximaal aantal pathogenen in het product. Zo mag geen Salmonella worden aangetroffen in $25 \mathrm{~g}$ of $25 \mathrm{ml}$ van het produt en dient het aantal organismen van Escherichia coli of Enterococcae niet meer te zijn dan 1000 in $1 \mathrm{~g}$ of $1 \mathrm{ml}$ van het product (eis anorganische meststof). Aangezien het de verwachting is dat het product geen C-organisch bevat, is deze eis niet relevant;

- Het product heeft tot doel planten van één of meer primaire of secundaire macronutriënten te voorzien (eis anorganische macronutriëntenmeststof). Product bevat alleen N;

- De grenswaarden voor zware metalengehalten (Tabel 5.2) mogen niet worden overschreden (eis anorganische macronutriëntenmeststof). Aangenomen wordt dat de hoeveelheid zware metalen die door het stripproces in het product terecht komen zeer klein is en dat de gehalten verwaarloosbaar zijn.

- Het product heeft een vloeibare vorm (eis vloeibare anorganische macronutriëntenmeststof);

- Het product bevat slechts één primair macronutriënt (eis enkelvoudige, vloeibare anorganische macronutriëntenmeststof). Product bevat alleen $\mathrm{N}$. 
- $\quad$ Aangezien het product uitsluitend $\mathrm{N}$ bevat, dient het $\mathrm{N}$-gehalte ten minste $5 \% \mathrm{~N}$ te zijn (eis enkelvoudige, vloeibare anorganische macronutriëntenmeststof). Uit tabel 5.4 blijkt dat het product hieraan voldoet.

Daarnaast voldoet het mineraal N-product (15-20\%) aan de RENURE-criteria, wat betekent dat de Ngift met dit product in de toekomst niet gebonden is aan het maximum van $170 \mathrm{~kg} \mathrm{~N} / \mathrm{ha}$ uit de Nitraatrichtlijn (Tabel 5.5).

Tabel 5.5 Europese en nationale eisen aan een mineraal $N$-product (15-20\%).

\begin{tabular}{|c|c|c|c|}
\hline EG Verordening 2003/2003 & EU Verordening 2019/1009 & $\begin{array}{l}\text { Nitraatrichtlijn } \\
\text { RENURE criteria in } \\
\text { voorbereiding }\end{array}$ & $\begin{array}{l}\text { Nederlandse } \\
\text { meststoffenwet }\end{array}$ \\
\hline
\end{tabular}

\subsection{K-product (5\%) Nederland, Duitsland, Frankrijk en grondstof}

Zoals in hoofdstuk 2 is aangegeven betreft het hier een mineraal $\mathrm{K}$-product met $5 \% \mathrm{~K}_{2} \mathrm{O}$, wat de resterende dunne fractie is na het strippen van de ammoniak. Daarbij zijn drie soorten kali-producten onderscheiden. De gehalten aan drogestof, organische stof en macronutriënten in het product zijn opgenomen in tabel 5.6.

Tabel 5.6 Samenstelling mineraal K-product (5\%) volgens 3 procesroutes, in \%.

\begin{tabular}{lllllllllll} 
Mineraal K-product, vergisting + RO/indampen & 15,3 & 6,7 & 1,36 & 0,51 & 0,84 & 0,10 & 5,0 & 0,21 & 0,20 \\
\hline Mineraal K-product, pyrolyse + RO/indampen & 25,3 & 10,8 & 2,68 & 0,35 & 2,33 & 0,11 & 5,0 & 0,22 & 0,21 \\
\hline Mineraal K-product, UF + RO/indampen & 16,3 & 3,8 & 0,10 & 0,08 & 0,03 & 0,04 & 5,0 & 0,22 & 0,21 \\
\hline
\end{tabular}

Het mineraal $\mathrm{K}$-product met $5 \% \mathrm{~K}_{2} \mathrm{O}$ kan op basis van de samenstelling in tabel 5.6 worden ingedeeld in PFC 1 C) I) b) i) Enkelvoudige (of samengestelde) vloeibare anorganische macronutriëntenmeststof. Als het C-organisch gehalte $>5 \%$, dan wordt het product geclassificeerd als PFC 1 A) II) Vloeibare, organische meststof. Eisen die aan een enkelvoudige vloeibare anorganische macronutriëntenmeststof worden gesteld zijn als volgt:

- Het product is een meststof die nutriënten in een minerale vorm bevat of afgeeft en die geen organische of organo-minerale meststof is (eis anorganische meststof);

- Als het product meer dan $1 \%$ C-organisch bevat, zijn er eisen aan het maximaal aantal pathogenen in het product. Zo mag geen Salmonella worden aangetroffen in $25 \mathrm{~g}$ of $25 \mathrm{ml}$ 
van het product en dient het aantal organismen van Escherichia coli of Enterococcae niet meer te zijn dan 1000 in $1 \mathrm{~g}$ of $1 \mathrm{ml}$ van het product (eis anorganische meststof). Aangezien het product naar verwachting $2-5 \%$ C-organisch bevat (4-11\% organische stof; tabel 5.6 ) is deze eis van toepassing;

- Het product heeft tot doel planten van één of meer primaire of secundaire macronutriënten te voorzien (eis anorganische macronutriëntenmeststof). Product bevat $\mathrm{K}$ en in meer of mindere mate $\mathrm{N}$ en heel weinig $\mathrm{P}$;

- De grenswaarden voor zware metalengehalten mogen niet worden overschreden (eis anorganische macronutriëntenmeststof). In tabel 5.7 zijn de berekende zware metalengehalten voor de 3 varianten van het mineraal K-product vergeleken met de EUnorm. Daaruit lijkt het risico van overschrijdingen beperkt te zijn.

Tabel 5.7 Gehalten aan zware metalen en de EU-norm voor PFC anorganische macronutriëntmeststoffen met $\mathrm{P}_{2} \mathrm{O}_{5}<5 \%$.

\begin{tabular}{|c|c|c|c|c|c|c|c|c|c|}
\hline \multirow[t]{2}{*}{ Product } & \multicolumn{9}{|c|}{ gehalten aan zware metalen in $\mathrm{mg} / \mathrm{kg}$ ds } \\
\hline & As & Cd & $\mathrm{Cr}$ & Cr VI & $\mathrm{Cu}$ & Hg & $\mathbf{N i}$ & $\mathrm{Pb}$ & $\mathbf{Z n}$ \\
\hline Mineraal K-product, vergisting $+\mathrm{RO}$ /indampen & 1,20 & 0,10 & 2,99 & & 203 & 0,09 & 5,07 & 3,55 & 878 \\
\hline Mineraal K-product, pyrolyse + RO/indampen & 0,76 & 0,07 & 1,88 & & 128 & 0,06 & 3,19 & 2,24 & 553 \\
\hline Mineraal K-product, UF + RO/indampen & 1,21 & 0,10 & 2,99 & & 204 & 0,09 & 5,08 & 3,56 & 879 \\
\hline EU-norm anorganische macronutriëntmeststof & 40 & 3 & & 2 & 600 & 1 & 100 & 120 & 1500 \\
\hline
\end{tabular}

- Het product heeft een vloeibare vorm (eis vloeibare anorganische macronutriëntenmeststof);

- Het product bevat een aangegeven gehalte van slechts één primair macronutriënt (eis enkelvoudige, vloeibare anorganische macronutriëntenmeststof). Product bevat vooral $\mathrm{K}$ en in twee van de drie gevallen $\mathrm{N}$.

- Aangezien het product uitsluitend $\mathrm{K}$ bevat, dient het $\mathrm{K}$-gehalte ten minste $3 \% \mathrm{~N}$ te zijn (eis enkelvoudige, vloeibare anorganische macronutriëntenmeststof). Uit tabel 5.6 blijkt dat het product hieraan voldoet.

Daarnaast voldoet het mineraal K-product (5\%) niet aan de RENURE-criteria (het N-mineraal-gehalte van $\mathrm{N}$-totaal bedraagt namelijk minder dan 90\%), wat betekent dat de $\mathrm{N}$-gift met dit product in de toekomst gebonden blijft aan het maximum van $170 \mathrm{~kg} \mathrm{~N} / \mathrm{ha}$ uit de Nitraatrichtlijn (Tabel 5.8). 
Tabel 5.8 Europese en nationale eisen aan een K-product (5\%).

\begin{tabular}{|c|c|c|c|}
\hline EG Verordening 2003/2003 & EU Verordening 2019/1009 & $\begin{array}{l}\text { Nitraatrichtlijn } \\
\text { RENURE criteria in } \\
\text { voorbereiding }\end{array}$ & $\begin{array}{l}\text { Nederlandse } \\
\text { meststoffenwet }\end{array}$ \\
\hline $\begin{array}{l}\text { Geen mogelijkheid om EG-label te } \\
\text { voeren. } \\
\text { Er is geen enkelvoudige } \\
\text { kaliummeststof opgenomen in } \\
\text { bijlage } \mathrm{I} \text {, wel samengestelde } \\
\text { waarvoor dan geldt dat ten minste } \\
3 \% \text { water oplosbaar kali } \mathrm{K}_{2} \mathrm{O} \text { ) } \\
\text { aanwezig moet zijn en de som van } \\
\text { de waardegevende bestanddelen } \\
\text { ten minste } 15 \% \text {. } \\
\text { Langs chemische weg en door } \\
\text { oplossing in water verkregen } \\
\text { product, stabiel bij atmosferische } \\
\text { druk; er mogen geen organische } \\
\text { nutriënten van plantaardige of } \\
\text { dierlijke oorsprong worden } \\
\text { toegevoegd }\end{array}$ & $\begin{array}{l}\text { Mogelijkheid om CE markering te } \\
\text { voeren onder PFC } 1 \mathrm{C} \text { ) I) b i): } \\
\text { enkelvoudige vloeibare } \\
\text { anorganische macro- } \\
\text { nutriëntenmeststof mits ten } \\
\text { minste } 3 \% \mathrm{~K}_{2} \mathrm{O} \text { aanwezig is. } \\
\text { Als er meer dan } 1 \% \text { C-organisch } \\
\text { aanwezig is, zijn eisen t.a.v. } \\
\text { pathogenen van toepassing. Dit } \\
\text { is het geval. } \\
\text { De eisen voor zware metalen } \\
\text { knellen waarschijnlijk niet }\end{array}$ & $\begin{array}{l}\text { Product beantwoordt niet } \\
\text { aan RENURE criteria } \rightarrow \\
\text { product houdt status } \\
\text { dierlijke mest }\end{array}$ & $\begin{array}{l}\text { Product valt onder de } \\
\text { begripsomschrijving } \\
\text { van dierlijke mest en } \\
\text { daardoor onder de } \\
\text { gebruiksbepalingen } \\
\text { van dierlijke mest } \\
\text { indien stikstof } \\
\text { aanwezig is. } \\
\text { Product zou in bijlage } \\
\text { Aa van de URMW } \\
\text { opgenomen moeten } \\
\text { worden om vrij } \\
\text { handelsverkeer } \\
\text { mogelijk te maken. }\end{array}$ \\
\hline
\end{tabular}

\subsection{Mineraal P-product. Duitsland, Frankrijk en Polen}

Zoals in hoofdstuk 2 is aangegeven betreft het hier een mineraal P-product dat ook N, K en S bevat. Ook zit er nog vrij veel organische stof (ca. 30\%) in. Op basis van de STRUBIAS-studie (Huygens et al., 2019-I) wordt CMC 12 voor precipitated phosphate salts \& derivates toegevoegd aan EU 2019/1009. Een van de eisen voor deze CMC is dat het organische C-gehalte niet hoger is dan $3 \%$ (ca. $6 \%$ OS). De gehalten aan drogestof, organische stof en macronutriënten in het product zijn opgenomen in tabel 5.9. Hieruit blijkt dat het OS-gehalte te hoog is om aan CMC 12 te voldoen, maar waarschijnlijk wel in aanmerking komt voor CMC 10.

Tabel 5.9 Samenstelling mineraal P-product, in \%.

$\begin{array}{lcccccccccc}\text { Product } & \mathrm{DS} & \mathrm{OS} & \mathrm{N} \text {-tot } & \mathrm{NH}_{4}-\mathrm{N} & \mathrm{NO}_{3}-\mathrm{N} & \mathrm{N} \text {-org } & \mathrm{P}_{2} \mathrm{O}_{5} & \mathrm{~K}_{2} \mathrm{O} & \mathrm{SO}_{3} & \mathrm{MgO} \\ \text { Mineraal P-product } & 85,0 & 29,5 & 1,06 & 0,13 & 0,93 & 34,3 & 2,3 & 14,8 & 1,1\end{array}$

Het mineraal P-product kan op basis van de samenstelling in tabel 5.9 worden ingedeeld in PFC 1 C) I) a) i) Enkelvoudige (of samengestelde) vaste anorganische macronutriëntenmeststof. Als het Corganisch gehalte $>15 \%$, dan wordt het product geclassificeerd als PFC 1 A) I) vaste, organische meststof. Eisen die aan een enkelvoudige vaste anorganische macronutriëntenmeststof worden gesteld zijn als volgt:

- Het product is een meststof die nutriënten in een minerale vorm bevat of afgeeft en die geen organische of organo-minerale meststof is (eis anorganische meststof);

- Als het product meer dan 1\% C-organisch bevat, zijn er eisen aan het maximaal aantal pathogenen in het product. Zo mag geen Salmonella worden aangetroffen in $25 \mathrm{~g}$ of $25 \mathrm{ml}$ van het product en dient het aantal organismen van Escherichia coli of Enterococcae niet meer te zijn dan 1000 in $1 \mathrm{~g}$ of $1 \mathrm{ml}$ van het product (eis anorganische meststof). Aangezien het product naar verwachting $14-15 \%$ C-organisch bevat (29,5\% organische stof; tabel 5.9) is deze eis van toepassing;

- Het product heeft tot doel planten van één of meer primaire of secundaire macronutriënten te voorzien (eis anorganische macronutriëntenmeststof). Product bevat $\mathrm{P}$ en daarnaast $\mathrm{K}, \mathrm{N}$ en $\mathrm{S}$;

- De grenswaarden voor zware metalengehalten mogen niet worden overschreden. In tabel 5.10 zijn de berekende zware metalengehalten voor het mineraal P-product vergeleken met 
de EU-normen. Daaruit lijkt het risico van overschrijding van de norm voor anorganische macronutriëntenmeststof beperkt te zijn. Als het product wordt gecategoriseerd als organische mest is er risico van overschrijding van de grenswaarde voor $\mathrm{Zn}$.

Tabel 5.10 Gehalten aan zware metalen en de EU-norm voor PFC anorganische macronutriëntenmeststof (PFC 1 C) I)) of organische mest (PFC 1 A).

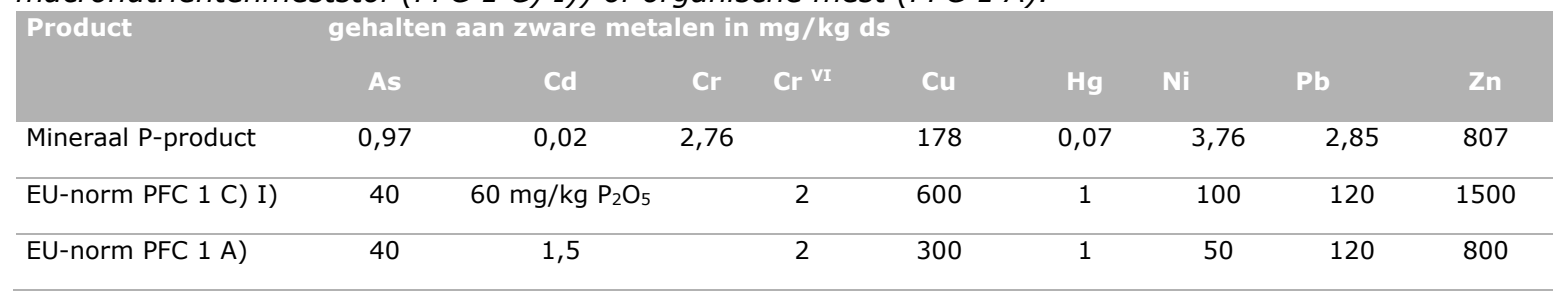

- Het product heeft een vaste vorm (eis vaste anorganische macronutriëntenmeststof);

- Het product bevat een aangegeven gehalte van slechts één primair macronutriënt (eis enkelvoudige, vaste anorganische macronutriëntenmeststof). Product bevat vooral $\mathrm{P}$ en daarnaast $\mathrm{K}, \mathrm{N}$ en $\mathrm{S}$;

- Aangezien het product uitsluitend $\mathrm{P}$ bevat, dient het $\mathrm{P}$-gehalte ten minste $12 \% \mathrm{P}_{2} \mathrm{O}_{5}$ te zijn (eis enkelvoudige, vaste anorganische macronutriëntenmeststof). Uit tabel 5.9 blijkt dat het product hieraan voldoet.

Daarnaast voldoet het mineraal P-product niet aan de RENURE-criteria (het N-mineraal-gehalte van $\mathrm{N}$ totaal bedraagt namelijk minder dan 90\%), wat betekent dat de $\mathrm{N}$-gift met dit product in de toekomst gebonden blijft aan het maximum van $170 \mathrm{~kg} \mathrm{~N} /$ ha uit de Nitraatrichtlijn (Tabel 5.11).

Tabel 5.11 Europese en nationale eisen aan een mineraal P product.

\begin{tabular}{|c|c|c|}
\hline $\begin{array}{l}\text { EG Verordening } \\
2003 / 2003\end{array}$ & EU Verordening 2019/1009 & $\begin{array}{l}\text { RENURE criteria in } \\
\text { voorbereiding }\end{array}$ \\
\hline
\end{tabular}

\subsection{P-houdend OS-product (85\% ds) Duitsland, Frankrijk, Polen en Oekraïne}

Zoals in hoofdstuk 2 is aangegeven betreft het hier een P-rijk organische stofproduct dat is gedroogd en gepelleteerd. Daarbij zijn 8 verschillende procesroutes onderscheiden, resulterend in producten met verschillende verhoudingen tussen de nutriënten. De basis wordt gevormd door de vaste fractie van varkensmest, maar bij alle producten is sprake van bijmenging met $\mathrm{N}$ - en/of K-kunstmest en in enkele gevallen met rundveemest en pluimveemest. De gehalten aan drogestof, organische stof en macronutriënten in het product zijn opgenomen in tabel 5.12. 
Tabel 5.12 Samenstelling organisch product (>85\% ds) volgens 8 procesroutes, in \%.

\begin{tabular}{|c|c|c|c|c|c|c|c|c|c|}
\hline Product & DS & os & N-tot & $\mathrm{NH}_{4}-\mathrm{N}$ & N-org & $\mathrm{P}_{2} \mathrm{O}_{5}$ & $\mathrm{~K}_{2} \mathrm{O}$ & $\mathrm{SO}_{3}$ & $\mathrm{MgO}$ \\
\hline Korrel: gedroogde vaste fractie, vark, $\mathrm{P}: \mathrm{K}=1: 3$ & 90 & 39,6 & 6,42 & 4,76 & 1,66 & 2,88 & 8,64 & 1,67 & 1,43 \\
\hline $\begin{array}{l}\text { Korrel: gedroogde vaste fractie, vark+kip+rund, } \\
P: K=1: 3\end{array}$ & 90 & 44,2 & 5,43 & 2,94 & 2,49 & 2,12 & 6,36 & 1,42 & 1,22 \\
\hline Korrel: gedroogde vaste fractie, vark, $\mathrm{P}: \mathrm{K}=1: 2$ & 90 & 54,9 & 2,16 & 0,07 & 2,09 & 3,99 & 7,98 & 2,32 & 1,98 \\
\hline Korrel: gedroogde vaste fractie, vark, $\mathrm{P}: \mathrm{K}=1: 1$ & 90 & 62,2 & 2,20 & 0,07 & 2,13 & 4,52 & 4,52 & 2,63 & 2,24 \\
\hline $\begin{array}{l}\text { Korrel: gedroogde gecomposteerde vaste fractie, } \\
\text { vark, } \mathrm{P}: \mathrm{K}=1: 3\end{array}$ & 90 & 31,2 & 7,41 & 5,94 & 1,47 & 3,41 & 10,24 & 1,98 & 1,69 \\
\hline $\begin{array}{l}\text { Korrel: gedroogde gecomposteerde vaste fractie, } \\
\text { vark+kip+rund, } \mathrm{P}: \mathrm{K}=1: 3\end{array}$ & 90 & 38,7 & 7,32 & 4,61 & 2,71 & 2,38 & 7,13 & 1,59 & 1,37 \\
\hline $\begin{array}{l}\text { Korrel: gedroogde gecomposteerde vaste fractie, } \\
\text { vark, } \mathrm{P}: \mathrm{K}=1: 2\end{array}$ & 90 & 47,2 & 2,08 & 0,12 & 1,96 & 5,20 & 10,40 & 3,02 & 2,58 \\
\hline $\begin{array}{l}\text { Korrel: gedroogde gecomposteerde vaste fractie, } \\
\text { vark, } \mathrm{P}: \mathrm{K}=1: 1\end{array}$ & 90 & 55,7 & 2,13 & 0,14 & 1,99 & 6,11 & 6,11 & 3,55 & 3,03 \\
\hline
\end{tabular}

Het P-houdend OS-product (85\%) kan op basis van het feit dat het gaat om een gecombineerde formulering van organische mest en kunstmest worden gecategoriseerd als PFC 1 B) I) Vaste organominerale meststof. Eisen die aan een vaste organo-minerale meststof worden gesteld zijn:

- De grenswaarden voor zware metalengehalten mogen niet worden overschreden (eis organominerale meststof). In tabel 5.13 zijn de berekende zware metalengehalten voor de 8 varianten van het P-houdend OS-product ( $85 \%$ ) vergeleken met de grenswaarden uit de EU-norm. Daaruit blijkt dat er bij een deel van de procesroutes sprake is van een risico van de overschrijding van de grenswaarde voor $\mathrm{Zn}$.

Tabel 5.13 Gehalten aan zware metalen in 8 producten en de EU-norm voor PFC organo-minerale meststoffen.

\begin{tabular}{|c|c|c|c|c|c|c|c|c|c|}
\hline \multirow[t]{2}{*}{ Product } & \multicolumn{9}{|c|}{ gehalten aan zware metalen in $\mathrm{mg} / \mathrm{kg}$ ds } \\
\hline & As & Cd & $\mathrm{Cr}$ & Cr vI & $\mathrm{Cu}$ & $\mathrm{Hg}$ & $\mathrm{Ni}$ & $\mathrm{Pb}$ & $\mathrm{Zn}$ \\
\hline Korrel: gedroogde vaste fractie, vark, $\mathrm{P}: \mathrm{K}=1: 3$ & 1,23 & 0,02 & 3,50 & & 226 & 0,09 & 4,76 & 3,62 & 1024 \\
\hline $\begin{array}{l}\text { Korrel: gedroogde vaste fractie, vark+kip+rund, } \\
\mathrm{P}: \mathrm{K}=1: 3\end{array}$ & 1,29 & 0,18 & 4,74 & & 126 & 0,08 & 3,93 & 4,88 & 359 \\
\hline Korrel: gedroogde vaste fractie, vark, $\mathrm{P}: \mathrm{K}=1: 2$ & 1,70 & 0,03 & 4,86 & & 313 & 0,13 & 6,60 & 5,02 & 1419 \\
\hline Korrel: gedroogde vaste fractie, vark, $\mathrm{P}: \mathrm{K}=1: 1$ & 1,93 & 0,03 & 5,50 & & 355 & 0,14 & 7,48 & 5,68 & 1606 \\
\hline $\begin{array}{l}\text { Korrel: gedroogde gecomposteerde vaste fractie, } \\
\text { vark, } P: K=1: 3\end{array}$ & 1,46 & 0,02 & 4,15 & & 268 & 0,11 & 5,65 & 4,29 & 1213 \\
\hline $\begin{array}{l}\text { Korrel: gedroogde gecomposteerde vaste fractie, } \\
\text { vark+kip+rund, } P: K=1: 3\end{array}$ & 1,45 & 0,20 & 5,31 & & 141 & 0,09 & 4,41 & 5,48 & 403 \\
\hline $\begin{array}{l}\text { Korrel: gedroogde gecomposteerde vaste fractie, } \\
\text { vark, } P: K=1: 2\end{array}$ & 2,22 & 0,04 & 6,33 & & 408 & 0,16 & 8,60 & 6,54 & 1848 \\
\hline $\begin{array}{l}\text { Korrel: gedroogde gecomposteerde vaste fractie, } \\
\text { vark, } \mathrm{P}: \mathrm{K}=1: 1\end{array}$ & 2,61 & 0,04 & 7,43 & & 480 & 0,19 & 10,10 & 7,68 & 2170 \\
\hline EU-norm organo-minerale meststof & 40 & 3 & & 2 & 600 & 1 & 100 & 120 & 1500 \\
\hline
\end{tabular}

- $\quad$ Er mag geen Salmonella worden aangetroffen in $25 \mathrm{~g}$ of $25 \mathrm{ml}$ van het product en het aantal organismen van Escherichia coli of Enterococcae dient niet meer te zijn dan 1000 in $1 \mathrm{~g}$ of $1 \mathrm{ml}$ van het product (eis anorganische meststof);

- Het product heeft een vast vorm (eis PFC 1 B I) Vaste organo-minerale meststof);

- Omdat het product meer dan één aangegeven primair nutriënt bevat, dienen die gehalten ten minste $2 \% \mathrm{~N}$ (waarvan $0,5 \%$ organische $\mathrm{N}$ is), $2 \% \mathrm{P}_{2} \mathrm{O}_{5}$ of $2 \% \mathrm{~K}_{2} \mathrm{O}$ te bedragen, waarbij de som van de nutriëntengehalten minimaal 8 massaprocent is $\rightarrow$ voldoet

- Het gehalte aan organisch koolstof (C-org) is tenminste 7,5\% $\rightarrow$ voldoet in alle gevallen 
- $\quad$ Elke korrel of pellet bevat organisch koolstof (C-org) en alle nutriënten in de aangegeven gehalten.

Daarnaast voldoet het mineraal P-product niet aan de RENURE-criteria (het N-mineraal-gehalte van Ntotaal bedraagt namelijk minder dan 90\%), wat betekent dat de $\mathrm{N}$-gift met dit product in de toekomst gebonden blijft aan het maximum van $170 \mathrm{~kg} \mathrm{~N} /$ ha uit de Nitraatrichtlijn (Tabel 5.14).

Tabel 5.14 Europese eisen aan een $P$-houdend OS product ( $85 \%$ ds).

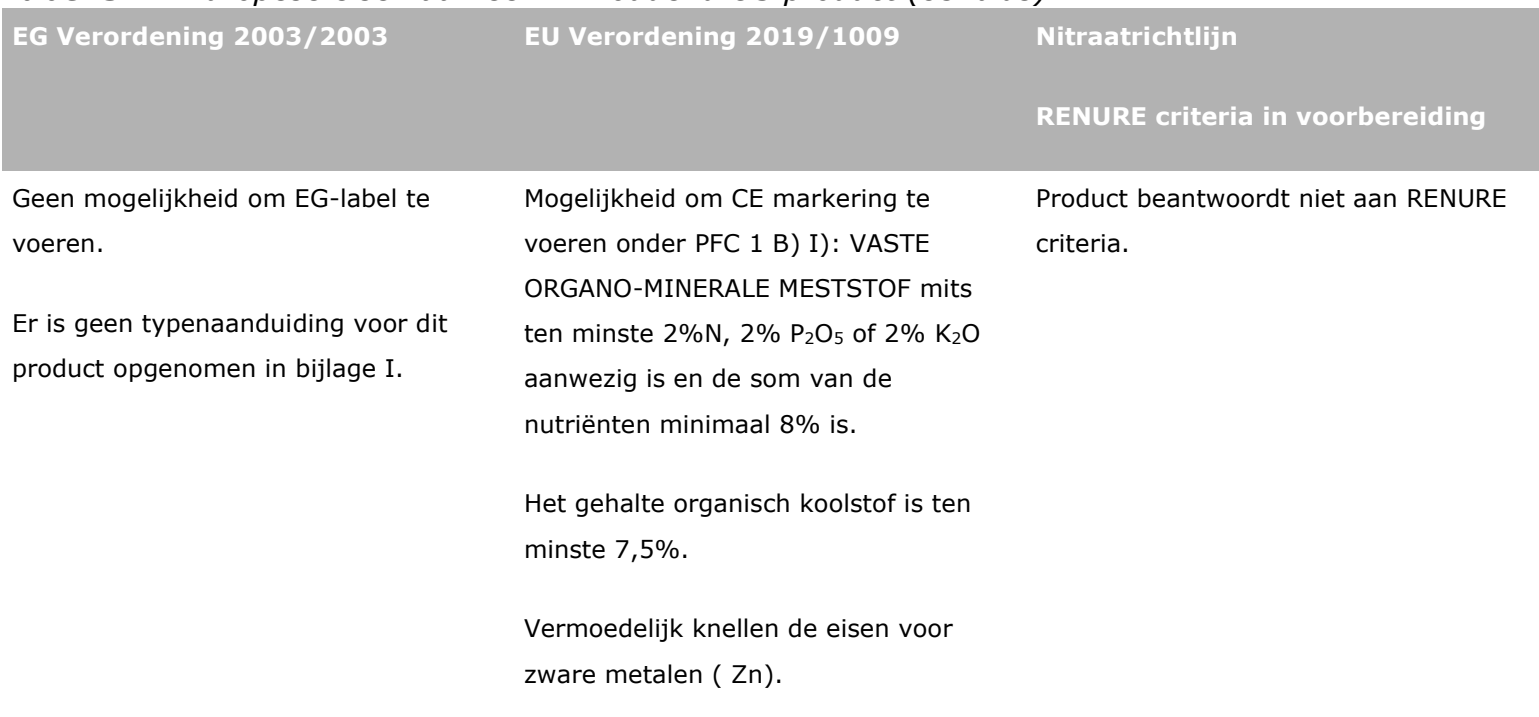

\subsection{P-houdend OS-product (50\% ds) Duitsland en Frankrijk}

Zoals in hoofdstuk 2 is aangegeven betreft het hier een P-rijk organische stofproduct dat is gecomposteerd. Daarbij zijn 4 verschillende procesroutes onderscheiden, resulterend in producten met verschillende verhoudingen tussen de nutriënten. De basis wordt gevormd door de vaste fractie van varkensmest, maar bij alle producten is sprake van bijmenging met $\mathrm{N}$ - en/of $\mathrm{K}$-kunstmest en in een geval met rundveemest en pluimveemest. De gehalten aan drogestof, organische stof en macronutriënten in het product zijn opgenomen in tabel 5.15 .

Tabel 5.15 Samenstelling organisch product (>50\% ds) volgens 4 procesroutes, in \%.

\begin{tabular}{|c|c|c|c|c|c|c|c|c|c|}
\hline Product & DS & os & N-tot & $\mathrm{NH}_{4}-\mathrm{N}$ & N-org & $\mathrm{P}_{2} \mathrm{O}_{5}$ & $\mathrm{~K}_{2} \mathrm{O}$ & $\mathrm{SO}_{3}$ & $\mathrm{MgO}$ \\
\hline Gecomposteerde vaste fractie, vark, $\mathrm{P}: \mathrm{K}=1: 2$ & 57,4 & 29,9 & 1,77 & 0,05 & 1,71 & 3,27 & 6,55 & 1,90 & 1,62 \\
\hline Gecomposteerde vaste fractie, vark, $\mathrm{P}: \mathrm{K}=1: 1$ & 53,4 & 32,7 & 1,75 & 0,06 & 1,69 & 3,58 & 3,58 & 2,08 & 1,78 \\
\hline
\end{tabular}

Het P-houdend OS-product (50\%) kan op basis van het feit dat het gaat om een gecombineerde formulering van organische mest en kunstmest worden gecategoriseerd als PFC 1 B) I) Vaste organominerale meststof. Eisen die aan een vaste organo-minerale meststof worden gesteld zijn:

- De grenswaarden voor zware metalengehalten mogen niet worden overschreden (eis organominerale meststof). In tabel 5.16 zijn de berekende zware metalengehalten voor de 4 varianten van het P-houdend OS-product (50\%) vergeleken met de grenswaarden uit de EU-norm. Daaruit blijkt dat er bij een deel van de procesroutes sprake is van een risico van de overschrijding van de grenswaarde voor $\mathrm{Zn}$. 
Tabel 5.16 Gehalten aan zware metalen en EU-normen voor PFC organo minerale meststoffen.

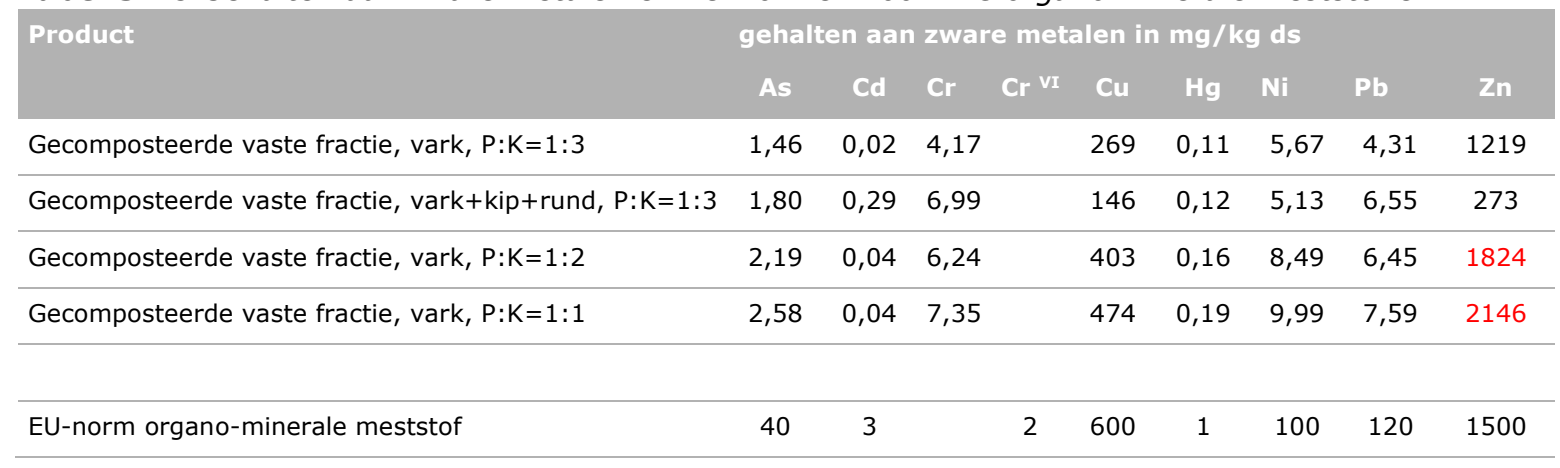

- $\quad$ Er mag geen Salmonella worden aangetroffen in $25 \mathrm{~g}$ of $25 \mathrm{ml}$ van het product en het aantal organismen van Escherichia coli of Enterococcae dient niet meer te zijn dan 1000 in $1 \mathrm{~g}$ of $1 \mathrm{ml}$ van het product (eis anorganische meststof);

- $\quad$ Het product heeft een vast vorm (eis PFC 1 B I) Vaste organo-minerale meststof);

- Omdat het product meer dan één aangegeven primair nutriënt bevat, dienen die gehalten ten minste $2 \% \mathrm{~N}$ (waarvan $0,5 \%$ organische $\mathrm{N}$ is), $2 \% \mathrm{P}_{2} \mathrm{O}_{5}$ of $2 \% \mathrm{~K}_{2} \mathrm{O}$ te bedragen, waarbij de som van de nutriëntengehalten minimaal 8 massaprocent is $\rightarrow$ voldoet

- Het gehalte aan organisch koolstof (C-org) is tenminste 7,5\% $\rightarrow$ voldoet in alle gevallen

- $\quad$ Elke korrel of pellet bevat organisch koolstof (C-org) en alle nutriënten in de aangegeven gehalten.

Daarnaast voldoet het mineraal P-product niet aan de RENURE-criteria (het N-mineraal-gehalte van $\mathrm{N}$ totaal bedraagt namelijk minder dan $90 \%$ ), wat betekent dat de $\mathrm{N}$-gift met dit product in de toekomst gebonden blijft aan het maximum van $170 \mathrm{~kg} \mathrm{~N} /$ ha uit de Nitraatrichtlijn (Tabel 5.17).

Tabel 5.17 Europese eisen aan een $P$-houdend OS product (50\% ds).

\begin{tabular}{|c|c|c|}
\hline EG Verordening 2003/2003 & EU Verordening 2019/1009 & $\begin{array}{l}\text { Nitraatrichtlijn } \\
\text { RENURE criteria in voorbereiding }\end{array}$ \\
\hline $\begin{array}{l}\text { Geen mogelijkheid om EG-label te } \\
\text { voeren. } \\
\text { Er is geen typenaanduiding voor dit } \\
\text { product opgenomen in bijlage I. }\end{array}$ & $\begin{array}{l}\text { Mogelijkheid om CE markering te } \\
\text { voeren onder PFC } 1 \text { B) I): VASTE } \\
\text { ORGANO-MINERALE MESTSTOF mits } \\
\text { ten minste } 2 \% \mathrm{~N}, 2 \% \mathrm{P}_{2} \mathrm{O}_{5} \text { of } 2 \% \mathrm{~K}_{2} \mathrm{O} \\
\text { aanwezig is en de som van de } \\
\text { nutriënten minimaal } 8 \% \text { is. } \\
\text { Het gehalte organisch koolstof is ten } \\
\text { minste } 7,5 \% \text {. } \\
\text { Vermoedelijk knellen de eisen voor } \\
\text { zware metalen }(\mathrm{Zn}) \text {. }\end{array}$ & $\begin{array}{l}\text { Product beantwoordt niet aan RENURE } \\
\text { criteria. }\end{array}$ \\
\hline
\end{tabular}

\subsection{P-arm OS-product Nederland}

Zoals in hoofdstuk 2 is aangegeven betreft het hier een P- arm organische stofproduct dat resteert na de extractie van het mineraal $P$ product. De gehalten aan drogestof, organische stof en macronutriënten in het product zijn opgenomen in tabel 5.18.

Tabel 5.18 Samenstelling P-arm os-product, in \%.

\begin{tabular}{lcccccccccc} 
Product & $\mathrm{DS}$ & $\mathrm{OS}$ & $\mathrm{N}$-tot & $\mathrm{NH}_{4}-\mathrm{N}$ & $\mathrm{NO}_{3}-\mathrm{N}$ & $\mathrm{N}$-org & $\mathrm{P}_{2} \mathrm{O}_{5}$ & $\mathrm{~K}_{2} \mathrm{O}$ & $\mathrm{SO}_{3}$ & $\mathrm{MgO}$ \\
P-arm OS-product & 32,3 & 22,8 & 1,18 & 0,46 & 0,72 & 0,35 & 0,39 & 3,3 & 0,8 \\
\hline
\end{tabular}

Zoals in hoofdstuk 2 al is aangegeven is het P-gehalte in dit product niet heel laag. 
Het P-arme OS-product kan op basis van de productiewijze en de samenstelling worden gecategoriseerd als PFC 3 A) Organische bodemverbeteraar. Eisen die aan een organische bodemverbeteraar worden gesteld zijn:

- Het product dient voor $95 \%$ te bestaan uit materialen van uitsluitend biologische oorsprong.

- $\quad$ Het product bevat ten minste $20 \%$ drogestof $\rightarrow$ voldoet (Tabel 5.18)

- $\quad$ Het product bevat ten minste 7,5\% organisch koolstof (C-organisch) $\rightarrow$ voldoet (tabel 5.18)

- De grenswaarden voor zware metalengehalten mogen niet worden overschreden (eis organische bodemverbeteraar). In tabel 5.19 zijn de berekende zware metalengehalten voor het P-arme OS-product vergeleken met de grenswaarde uit de EU-norm. Daaruit blijkt dat er sprake is van een risico van de overschrijding van de grenswaarde voor $\mathrm{Cu}$ en $\mathrm{Zn}$.

Tabel 5.19 Gehalten aan zware metalen en normen in EU verordening 2019/1009 (PFC organische meststof).

\begin{tabular}{|c|c|c|c|c|c|c|c|c|c|}
\hline \multirow[t]{2}{*}{ Product } & \multicolumn{9}{|c|}{ gehalten aan zware metalen in $\mathrm{mg} / \mathrm{kg}$ ds } \\
\hline & As & Cd & $\mathrm{Cr}$ & Cr vI & $\mathrm{Cu}$ & $\mathrm{Hg}$ & Ni & $\mathbf{P b}$ & $\mathrm{Zn}$ \\
\hline P-arm OS-product & 1,97 & 0,03 & 5,63 & & 363 & 0,15 & 7,65 & 5,82 & 1644 \\
\hline EU-norm organische bodemverbeteraar & 40 & 2 & & 2 & 300 & 1 & 50 & 120 & 800 \\
\hline
\end{tabular}

- De Cu- en Zn-gehalten die zijn weergegeven in tabel 5.19 zijn afgeleid van de gehalten in de vaste fractie van varkensmest volgens Hoeksma et al. (2011) en een aangenomen verdeling over de minerale P-fractie en de na de P-extractie resterende P-arme vaste fractie (conform verdeling organische stof). In het Horizon 2020-project Systemic zijn metingen verricht aan de samenstelling van de na P-extractie resterende vaste fractie. Deze gehalten waren voor zowel zink als koper aanzienlijk lager en bedroegen $115 \mathrm{mg} \mathrm{Cu} / \mathrm{kg}$ ds en $352 \mathrm{mg} \mathrm{Zn/kg} \mathrm{ds}$ (persoonlijke mededeling P. Ehlert). Deze gehalten komen overeen met metingen aan de dikke fractie die in 2019/2020 zijn verricht door Hoeksma.

- $\quad$ Er mag geen Salmonella worden aangetroffen in $25 \mathrm{~g}$ of $25 \mathrm{ml}$ van het product en het aantal organismen van Escherichia coli of Enterococcae dient niet meer te zijn dan 1000 in $1 \mathrm{~g}$ of $1 \mathrm{ml}$ van het product (eis organische bodemverbeteraar).

Daarnaast voldoet het mineraal P-product niet aan de RENURE-criteria (het $\mathrm{N}$-mineraal-gehalte van $\mathrm{N}$ totaal bedraagt namelijk minder dan 90\%), wat betekent dat de $\mathrm{N}$-gift met dit product in de toekomst gebonden blijft aan het maximum van $170 \mathrm{~kg} \mathrm{~N} / \mathrm{ha}$ uit de Nitraatrichtlijn.

Product valt onder de begripsomschrijving van dierlijke mest en daardoor onder de gebruiksbepalingen van dierlijke mest. $\mathrm{Er}$ is in Nederland één producent die dit product gaat maken.

Het ministerie LNV zal waarschijnlijk een pilot met 10 demovelden goedkeuren waarbij het product zijnde dierlijke mest aangewend mag worden onder toepassing van een stikstofwerkingscoëfficiënt van $10 \%$ en onder verrekening van de fosfaatvrije voet $(50 \%)$. 


\section{$6 \quad$ Conclusies}

\subsection{Risico van aanwezigheid contaminanten}

$\mathrm{Er}$ is een inschatting gemaakt van de verwachte gehalten aan contaminanten in de mestproducten:

- De gehalten aan zware metalen in de mestproducten zijn afgeleid van de gehalten in de grondstoffen en de massabalansen van de productieprocessen. Daarbij is er vanuit gegaan dat de verdeling van zware metalen over verschillende mestfracties gekoppeld is aan de verdeling van de organische stof over de mestfracties. Daardoor worden de hoogste gehalten aan zware metalen gevonden in de organische stofrijke producten. Dit geldt dus vooral voor het mineraal Pproduct (ca. 30\% OS), de P-rijke organische stofproducten (zowel 50\% en $85 \%$ ds) en het Parme OS-product. Vooral koper $(\mathrm{Cu})$ en zink $(\mathrm{Zn})$ vormen een aandachtspunt in verband met wettelijke normen (zie verder bij wet- en regelgeving).

- $\quad$ Op basis van schaarse metingen die zijn gedaan aan organische microverontreinigingen in onbewerkte mesten en mineralenconcentraten, kan worden geconcludeerd dat het risico van de overschrijding van normen voor organische microverontreinigingen zeer klein is.

- Aangezien het gebruik van antibiotica in de veehouderij tussen 2007 en 2016 flink is afgenomen, zal dat ook gelden voor gehalten aan antibiotica in dierlijke mest. Deze gehalten hangen o.a. af van de opname door het dier en de stabiliteit van het antibioticum in mest. Mestverwerking kan leiden tot een beperkte daling van antibioticaresiduen in mestproducten.

- De belangrijkste ziekteverwekkende (of pathogene) organismen zijn Escherichia coli serotype 0157:H7, de Salmonella enterica, Campylobacter spp., Cryptosporidium parvum en Giardia duodenalis. In een onderzoek kwam de pathogene $E$. coli in $44 \%$ van varkensmestmonsters voor, terwijl dat bij rundveemest in $17 \%$ van de monsters het geval was. Opslag van mest leidt tot een afname van het aantal micro-organismen, maar bij lage temperaturen is dat effect beperkt. Daarnaast hebben de volgende behandelingen een effect:

- Anaerobe vergisting leidt tot een afname van de aantallen micro-organismen, maar daarbij moet onderscheid worden gemaakt naar thermofiele vergisting (temperaturen van $50-55^{\circ} \mathrm{C}$ ), waarbij vrijwel alle organismen worden geïnactiveerd, en mesofiele vergisting $\left(35-40{ }^{\circ} \mathrm{C}\right)$ en psychrofiele vergisting $\left(<20^{\circ} \mathrm{C}\right)$, waarbij dat in veel mindere mate het geval is.

- Compostering leidt tot een afname van het aantal micro-organismen, maar dit is vooral het geval als de temperatuur stijgt tot $60^{\circ} \mathrm{C}$ of hoger;

- Verhitting tot $55^{\circ} \mathrm{C}$ of hoger leidt in het algemeen tot effectieve inactivatie van microorganismen, maar sporen van bijvoorbeeld Coxiella burnetii of Cryptosporidium spp. kunnen dit overleven.

- Bij omgekeerde osmose blijven de micro-organismen achter in het concentraat en is het effluent microbiologisch schoon.

- $\quad$ Bij varkensmest is het risico van het verspreiden van onkruid kleiner dan bij rundveemest en daarnaast leidt langdurige opslag tot een afname van de kiemkracht van onkruidzaden. Vergisting van mest leidt vooral bij varkensdrijfmest tot een afname van het aantal vitale onkruidzaden. Ook drogen bij $75^{\circ} \mathrm{C}$ gevolgd door korrelen leidt tot een zeer gering risico van overleving van onkruidzaden. Het risico van verontreinigingen in de vorm van glas en plastic in mestproducten is zeer klein.

- $\quad$ Bij mestverwerking wordt gebruik gemaakt van vlokmiddelen, waaronder polymeren, zoals polyacrylamide. Op termijn moeten de polymeren in CE-meststoffen volledig biologisch afbreekbaar zijn. 


\subsection{Europese wet- en regelgeving}

De Europese regelgeving voor vrijhandelsverkeer van meststoffen en het gebruik van stikstofhoudende bemestingsproducten gebaseerd op dierlijke mest maken op dit moment (juni 2020) een ontwikkeling door die nog niet een eindfase bereikt hebben. Dit betekent dat deze rapportage moet worden beschouwd als voorlopig.

In de nieuwe Europese Meststoffenverordening 2019/1009 worden productfunctiecategorieën (PFC's) en bestanddelencategorieën (CMC's) onderscheiden. Mestproducten die voldoen aan de eisen van de beschreven PFC's en die een conformiteitsbeoordeling (= het proces waarin wordt aangetoond dat voldaan is aan de eisen van verordening EU 2019/1009) hebben doorlopen kunnen een CE-markering voeren. Een meststof komt alleen in aanmerking om ingedeeld te worden in een PFC als de meststof vervaardigd is uit een schone grondstof (CMC). Voor producten uit mest gaat het daarbij om bestanddelencategorie CMC 10, die nog niet is ingevuld. Dat betekent dat nog niet definitief is welke eisen er gesteld gaan worden aan mestverwerkingsproducten die gebruikt worden als grondstof voor een meststof. We nemen hier echter aan dat bemestingsproducten van dierlijke mest gesaniteerd dienen te zijn.

Stikstofhoudende meststofproducten die uit dierlijke mest worden vervaardigd worden in principe geclassificeerd als dierlijke mest, waardoor ze vallen onder de gebruiksbepalingen van de Nitraatrichtlijn voor dierlijke mest. Dit betekent dat de maximale gift voor deze en andere producten uit dierlijke mest $170 \mathrm{~kg} \mathrm{~N} / \mathrm{ha} /$ jaar bedraagt. In het project Safemanure is door het Joint Research Centre (JRC) onderzocht onder welke criteria stikstofhoudende bemestingsproducten uit dierlijke mest volgens dezelfde bepalingen gebruikt kunnen worden als stikstof van gangbare minerale meststoffen (kunstmest). De betreffende producten zijn aangeduid als Recovered Nitrogen from MANure (RENURE). Er is door JRC in 2019 een concept-rapport uitgebracht waarin de RENURE-criteria zijn beschreven, maar dit is nog niet definitief. Een belangrijk criterium is dat het $\mathrm{N}$-mineraal-gehalte van $\mathrm{N}$-totaal minimaal $90 \%$ bedraagt. Daarnaast zijn er grenswaarden voor de gehalten aan de zware metalen koper $(\mathrm{Cu})$, kwik ( $\mathrm{Hg})$ en zink $(\mathrm{Zn})$ geformuleerd $(\mathrm{Cu}<300 \mathrm{mg} / \mathrm{kg}$ ds, $\mathrm{Hg}<1 \mathrm{mg} / \mathrm{kg}$ ds en $\mathrm{Zn}<800 \mathrm{mg} / \mathrm{kg} \mathrm{ds}$ ). Deze criteria zijn dan ook voorlopig.

In tabel 6.1 is samengevat hoe de mestproducten uit deze studie kunnen worden ingedeeld in een productfunctiecategorie (PFC) uit de nieuwe Europese Meststoffenverordening 2019/1009, of ze voldoen aan de RENURE-criteria en of er knelpunten worden voorzien met betrekking tot bepaalde criteria ten aanzien van contaminanten.

Tabel 6.1 Samenvatting van de indeling van mestproducten in de PFC's van EU 2019/1009, met opmerkingen en eventueel voorziene knelpunten. Voor toelichting zie tekst.

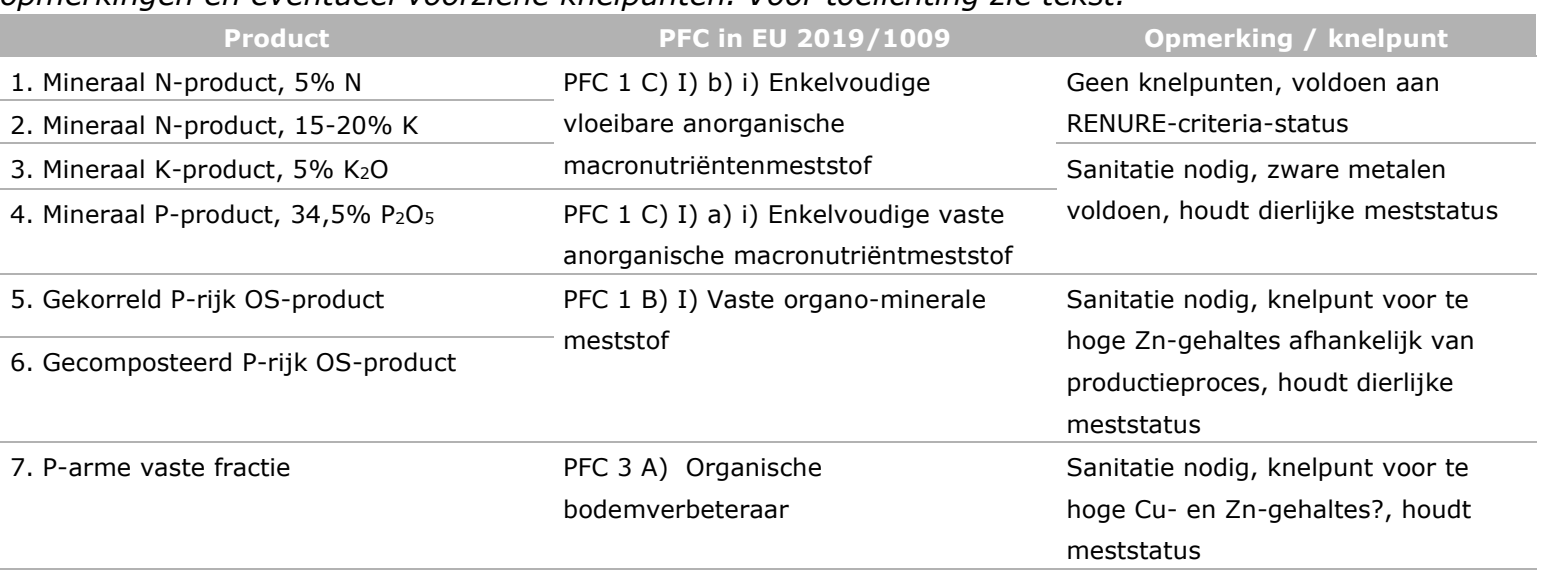

Opmerkingen bij Tabel 6.1:

- Producten 1 en 2 (minerale N-producten met 5 of $15-20 \% \mathrm{~N}$ ) worden ingedeeld in PFC 1 C) I) b) i) Enkelvoudige vloeibare anorganische macronutriëntenmeststof en er zijn geen knelpunten te verwachten ten aanzien van zware metalen. Aangezien het organisch koolstofgehalte (C-org) naar verwachting lager zal zijn dan 1\%, worden er geen eisen gesteld aan het aantal pathogene microorganismen en lijkt een sanitatie niet nodig, maar dit is nog onzeker i.v.m. de criteria voor CMC 10. Belangrijk voor deze producten is dat ze voldoen aan de RENURE-criteria, wat betekent dat de 
$\mathrm{N}$-gift met dit product in de toekomst niet gebonden is aan het maximum van $170 \mathrm{~kg} \mathrm{~N} / \mathrm{ha}$ uit de Nitraatrichtlijn.

- $\quad$ Product 3 (mineraal K-product met 5\% $\mathrm{K}_{2} \mathrm{O}$ ) kan eveneens worden ingedeeld in PFC $1 \mathrm{C}$ ) I) b) i) Enkelvoudige vloeibare anorganische macronutriëntenmeststof. Er zijn geen knelpunten te verwachten ten aanzien van zware metalen. Aangezien het organisch koolstofgehalte tussen 2 en $5 \%$ ligt, worden er eisen gesteld aan het aantal pathogene micro-organismen en lijkt een sanitatie nodig. Het product voldoet niet aan RENURE-criteria, houdt de status van dierlijke mest en blijft voor de N-gift gebonden aan het maximum van $170 \mathrm{~kg} \mathrm{~N} /$ ha uit de Nitraatrichtlijn.

- $\quad$ Product 4 (mineraal P-product) kan worden ingedeeld in PFC $1 \mathrm{C}$ ) I) a) i) Enkelvoudige vaste anorganische macronutriëntmeststof. Als het C-organisch gehalte $>15 \%$, dan wordt het product geclassificeerd als PFC 1 A) I) vaste, organische meststof. Er zijn geen knelpunten te verwachten ten aanzien van zware metalen, tenzij het wordt ingedeeld als organische meststof. In dat geval lijkt de Zn-norm een knelpunt te vormen. Aangezien het organisch koolstofgehalte tussen 12 en $15 \%$ ligt, worden er eisen gesteld aan het aantal pathogene micro-organismen en lijkt een sanitatie nodig. Het product voldoet niet aan RENURE-criteria, houdt de status van dierlijke mest en blijft voor de N-gift gebonden aan het maximum van $170 \mathrm{~kg} \mathrm{~N} /$ ha uit de Nitraatrichtlijn.

- Producten 5 en 6 (P-rijke OS-producten met $85 \%$ of $50 \%$ DS) kunnen worden ingedeeld in PFC 1 B) I) Vaste organo-minerale meststof. Afhankelijk van de wijze waarop dit product wordt gemaakt, kan er sprake zijn van een risico van de overschrijding van de grenswaarde voor $Z n$. Wellicht is dit niet het geval als de Zn-gehalten in varkensdrijfmest lager zijn dan de uitgangspunten die in deze studie zijn gehanteerd (gebaseerd op Hoeksma et al., 2011). De kans is groot dat de $\mathrm{Zn}$-gehalten in de meeste varkensdrijfmesten lager zijn dan de gehalten waar we hier vanuit zijn gegaan. Dit blijkt uit cijfers van Römkens \& Rietra (2008), Klein \& Roskam (2018) en recente metingen van Hoeksma uit 2019/2020. Er worden eisen gesteld aan het aantal pathogene micro-organismen en een sanitatie lijkt nodig. De producten voldoet niet aan RENUREcriteria, houden de status van dierlijke mest en blijven voor de N-gift gebonden aan het maximum van $170 \mathrm{~kg} \mathrm{~N} /$ ha uit de Nitraatrichtlijn.

- $\quad$ Product 7 (P-arme vaste fractie) kan worden ingedeeld in PFC 3 A) Organische bodemverbeteraar. Er lijkt op basis van de uitgangspunten in deze studie sprake te zijn van een risico dat Cu- en $\mathrm{Zn}$ normen worden overschreden, maar uit metingen die in het project Systemic zijn gedaan blijkt dat de Cu- en Zn-gehalten aanzienlijk lager zijn, waardoor wel kan worden voldaan aan de normen. Het product voldoet niet aan RENURE-criteria, houdt de status van dierlijke mest en blijft voor de N-gift gebonden aan het maximum van $170 \mathrm{~kg} \mathrm{~N} /$ ha uit de Nitraatrichtlijn. Aangezien dit product vooral in Nederland zal worden toegepast, lijkt een CE-markering voor dit product niet/nauwelijks van belang. 


\section{Literatuur}

CDM (2016). Protocol beoordeling stoffen meststoffenwet. Versie 3.2. Wageningen, Wettelijke onderzoekstaken Natuur \& Milieu, WOt-technical report 71, 7- blz.

Compendium voor de Leefomgeving (2019) Gebruik van antibiotica in de veehouderij en resistentie, 1999-2018. Beschikbaar via www.clo.nl.

CSES (2010). Centre for Strategy \& Evaluation Services, Evaluation of Regulation 2003/2003 relating to fertilisers, Final Report, November 2010.

http://ec.europa.eu/smartregulation/evaluation/search/download.do?documentId=4416.

Doude van Troostwijk (2002) Optimalisatie coagulatie bij behandeling oppervlaktewater tot drinkwater. H2O nr. 24, 40-42.

Driessen JJM \& AH Roos (1996). Inventarisatie van het gehalte aan zware metalen en organische microverontreinigingen in meststoffen. Rikilt-rapport 96.14.

Ehlert P.A.I., P. Hoeksma \& G.L. Velthof (2009) Anorganische en organische microverontreinigingen in mineralenconcentraten. Rapport nummer 256, Animal Science Group, Wageningen UR.

Ehlert, P.A.I. \& O.F. Schoumans (2015). Products, by-products and recovered secondary materials from processed animal manure. Wageningen, Alterra Wageningen UR (University \& Research centre), Alterra report 2668. https://edepot.wur.nl/365933.

Elema AG \& Scheepens PC (1992) Verspreiding van onkruiden en planteziekten met dierlijke mest; een risico-analyse. PAGV publicatienr. 62, PAGV, Lelystad.

EMA, 2018. EMA (2018). Sales of veterinary antimicrobial agents in 30European countries in 2016.

Hoeksma, P., F.E. de Buisonjé, P.A.I. Ehlert \& J.H. Horrevorts (2011). Mineralenconcentraten uit dierlijke mest Monitoring in het kader van de pilot mineralenconcentraten. Wageningen Livestock Research, rapport 481.

Hoeksma P, Rutjes S, Aarnink A, Blaak H \& de Buisonjé F (2016) Overleving van pathogenen bij mestverwerking. H2O-online, maart 2016.

Hussein, H.S., Bollinger, L.M. (2005). Prevalence of Shiga Toxin - Producing Escherichia coli in Beef Cattle. J. Food Prot. 68, 2224-2241.

Huygens D, Saveyn HGM, Tonini D, Eder P, Delgado Sancho L, (2019-I) Technical proposals for selected new fertilising materials under the Fertilising Products Regulation (Regulation (EU) 2019/1009) - Process and quality criteria, and assessment of environmental and market impacts for precipitated phosphate salts \& derivates, thermal oxidation materials \& derivates and pyrolysis \& gasification materials, EUR 29841 EN, Publications Office of the European Union, Luxembourg, 2019, ISBN 978-92-76-09888-1, doi:10.2760/186684, JRC117856.

Huygens D, Orveillon G, Lugato E, Tavazzi S, Comero S, Jones A, Gawlik B \& Saveyn H (2019-II) Safemanure: Developing criteria for safe use of processed manure in Nitrates Vulnerable Zones above the threshold established by the Nitrates Directive. Draft Interim Report, European Commission, DG Joint Research Centre (JRC), September, 2019.

Kivits et al 2017 Kivits, T., Broers, H. P., Beeltje, H., Griffioen, J., \& van Vliet, M. (2017). Antibiotica in grondwater onder intensieve veehouderijgebieden. [29] Water Matters-kennismagazine voor waterprofessionals, 8-11.

Klein J \& G Roskam (2018). Zware metalen in mest in 2017. Deltares. Rapport 11202236-002-BGS0001.

Lahr J, Moermond C, Montforts M, Derksen A, Bondt N, Puister-Jansen L, de Koeijer T en Hoeksma P (2019) Diergeneesmiddelen in het milieu - Een synthese van de huidige kennis. STOWA rapport no. 2019-26.

MARAN (2019) Monitoring of antimicrobial resistance and antibiotic usage in animals in the Netherlands in 2018.

Römkens, P.F.A.M. \& R.P.J.J. Rietra (2008). Zware metalen en nutriënten in dierlijke mest 2008. Gehalten aan $\mathrm{Cd}, \mathrm{Cr}, \mathrm{Cu}, \mathrm{Hg}, \mathrm{Ni}, \mathrm{Pb}, \mathrm{Zn}, \mathrm{As}, \mathrm{N}$ en $\mathrm{P}$ in runder-, varkens- en kippenmest. Alterra rapport 1729. 
Schmitt, H., Blaak, H., Kemper, M., van Passel, M. W., Hierink, F., van Leuken, J., \& de Man, H. (2017). Bronnen van antibioticaresistentie in het milieu en mogelijke maatregelen.

Schoumans et al. (2017). Chemical phosphorus recovery from animal manure and digestate. Laboratory and pilot experiments. Wageningen Environmetal Research Report 2849.

Sda, 2019. SDa (2019) Het gebruik van antibiotica bij landbouwhuisdieren in 2018. SDa, Autoriteit Diergeneesmiddelen.

Singer, A. C., Shaw, H., Rhodes, V., \& Hart, A. (2016). Review of antimicrobial resistance in the environment and its relevance to environmental regulators. Frontiers in microbiology, 7. https://www.ncbi.nlm.nih.gov/pmc/articles/PMC5088501.

Van den Meersche T, Rasschaert G, Haesebrouck F (2019) Presence and fate of antibiotic residues, antibiotic resistance genes and zoonotic bacteria during biological swine manure treatment. Ecotoxicol Environ Saf. 2019; 175:29-38.

Van Dijk, W., R. Postma, L. Gollenbeek, P. Mostert, J. Roefs \& N. Verdoes (2020-I). Behoefte mestbewerkingsproducten in Nederland en Europa. Inventarisatie perspectiefvolle product-markt-combinaties. Rapportage WP1 in voorbereiding.

Van Dijk, W., R. Postma \& J. Roefs (2020-II). Landbouwkundige waarde mestproducten. Aanvoer van nutriënten en organische stof van in 2019 geselecteerde Product-Markt-Combinaties. Rapportage WP1 in voorbereiding.

Van Leuken JPG, Hoeksma P, Nijsten DRE, Schijven JF, Schmitt H \& de Roda Husman AM (2017) Verkenning van de microbiologischerisico's van mest voor de gezondheid; Op basis van een systematisch literatuuronderzoek. RIVM Rapport 2017-0100. 


\section{Bijlage 1 Overzicht Product-Markt Combinaties}

\begin{tabular}{|c|c|c|c|c|}
\hline \multirow[t]{2}{*}{ Product } & \multirow[t]{2}{*}{ Toepassingsgebied } & \multicolumn{2}{|c|}{ Potentieel volume, $\mathrm{mlj} \mathrm{kg}$} & \multirow[b]{2}{*}{$\mathrm{K} 2 \mathrm{O}$} \\
\hline & & $\mathrm{N}$ & P2O5 & \\
\hline & & & & \\
\hline & 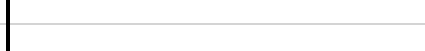 & & & \\
\hline \multirow[t]{6}{*}{ Mineraal- $\mathrm{N}$-product, $5 \% \mathrm{~N}$} & Melkvee NL & 135 & & \\
\hline & Duitsland, totaal & 1675 & & \\
\hline & Niedersachsen & 250 & & \\
\hline & Nordrhein-Westfalen & 147 & & \\
\hline & Frankrijk, totaal & 2191 & & \\
\hline & Lorraine & 123 & & \\
\hline \multirow[t]{6}{*}{ Mineraal-N-product, $15-20 \% \mathrm{~N}$} & Duitsland & 1675 & & \\
\hline & Frankrijk & 2191 & & \\
\hline & Melkvee NL & 135 & & \\
\hline & Grasland & 120 & & \\
\hline & Akkerbouw NL & 60 & & \\
\hline & Europa, overig & 7121 & & \\
\hline \multirow[t]{4}{*}{ K-product, $5 \%$} & NL akkerbouw & & & 25 \\
\hline & Champagne-Ardenne & & & 54 \\
\hline & Lorraine & & & 21 \\
\hline & Als grondstof voor andere meststoffen & & & \\
\hline \multirow[t]{5}{*}{ Mineraal-P-product, calciumfosfaat } & EU-totaal & & 2708 & \\
\hline & Duitsland & & 284 & \\
\hline & Frankrijk & & 474 & \\
\hline & Polen & & 341 & \\
\hline & Kunstmestindustrie, NL (ICL) & & 150 & \\
\hline P-houdend os-product, gedroogd 'ideaal' product & Duitsland & & 284 & \\
\hline \multirow[t]{3}{*}{$(85 \%$ ds) } & Frankrijk & & 474 & \\
\hline & Polen & & 341 & \\
\hline & Oekraïne & & 363 & \\
\hline P-houdend os-product, gecomposteerd 'ideaal' product & Duitsland, totaal & & & \\
\hline \multirow[t]{3}{*}{$(50 \% \mathrm{ds})$} & Niedersachsen & & 35 & \\
\hline & Nordrhein-Westfalen & & 8 & \\
\hline & Frankrijk & & & \\
\hline
\end{tabular}




\section{Bijlage 2 Overzicht inhoud Verordening (EG) nr. 2003/2003}

Overzicht inhoud Verordening (eg) nr. 2003/2003 van het Europees Parlement en de Raad van 13 oktober 2003 inzake meststoffen

Titel I. Algemene bepalingen

Hoofdstuk I. Werkingssfeer en definities

Geeft de werkingssfeer voor meststoffen met het 'EG-label' die in de handel worden gebracht en de begripsomschrijvingen.

Hoofdstuk II. In de handel brengen

Bepaalt voorwaarden voor 'EG-label', vestiging van de producent in de EG (EU), vrij handelsverkeer, verplichte vermeldingen, identificatie en identificatie gegevens, traceerbaarheid, etikettering, talen binnen EG, verpakking, tolerantiegrenzen, generieke eisen aan meststoffen t.a.v. doelmatigheid, beschikbaarheid van relevante bemonsterings-, analyse- en beproevingsmethoden en milieubezwaarlijkheid en de vrijwaringsclausule voor een lidstaat in geval een meststof niet aan gestelde generieke eisen kan worden voldaan.

Titel II. Bepalingen voor specifieke typen meststoffen

Hoofdstuk I. Anorganische meststoffen met primaire nutriënten

Hoofdstuk II. Anorganische meststoffen met secundaire nutriënten

Hoofdstuk III. Anorganische meststoffen met micronutriënten

Hoofdstuk IV. Meststoffen op basis van ammoniumnitraat en met een hoog stikstofgehalte In deze hoofdstukken I t/m IV worden bepalingen t.a.v. werkingssfeer en identificatie gegeven. Daarnaast worden bepalingen gegeven hoe secundaire nutriënten bij meststoffen voor primaire nutriënten gedeclareerd moeten worden. Voor meststoffen met micronutriënten worden specifieke verpakkingsvoorschriften voorgeschreven. Hoofdstuk IV geeft specifieke bepalingen voor beheersing van enig risico op detonatie door middel van specifieke voorschriften t.a.v. veiligheid en controle, voorschriften voor detonatieproeven en verpakking.

Titel III. Conformiteitsbeoordeling van meststoffen

Onder deze titel worden twee artikelen gegeven die lidstaten machtigen om de conformiteit van een meststof met het EG-label te toetsen aan de bepalingen van EG Verordening 2003/2003. Daarnaast wijzen lidstaten conformiteitslaboratoria aan die gemachtigd worden om op conformiteit te toetsen. Tenslotte wordt de Europese Commissie de bevoegdheid gegeven om de EU Verordening aan te passen aan vernieuwende inzichten.

Titel IV. Slotbepalingen

In dit afsluitende hoofdstuk worden de bepalingen voor de procedures gegeven voor opname van nieuwe meststoffen in de verordening, aanpassingen van de bijlagen, sancties en overgangsbepalingen en -termijnen.

Bijlage I. Lijst van de typen EG-meststoffen

Deze bijlage geeft een volledig overzicht van alle typeaanduidingen voor EG-meststoffen. Voor kalkmeststoffen gelden de bepalingen van EU

Bijlage II. Toleranties

De bijlage geeft per typeaanduiding de toegelaten toleranties.

Bijlage III. Technische bepalingen voor meststoffen op basis van ammoniumnitraat en met een hoog stikstofgehalte 
Hierin worden de kenmerken van en grenswaarden voor enkelvoudige meststoffen op basis van ammoniumnitraat en met een hoog stikstofgehalte geven. Daarnaast wordt de detonatieproef beschreven en methoden om te controleren of aan grenswaarden wordt voldaan.

Bijlage IV. Bemonsterings- en analysemethoden

Deze bijlage geeft het overzicht van alle aangewezen bemonsterings- en analysemethoden van meststoffen ten dienste van controle.

Bijlage V.

A. Lijst van documenten die door de fabrikanten of hun vertegenwoordigers moeten worden geraadpleegd om een technisch dossier samen te stellen voor de opname van een nieuw type meststof in bijlage i van deze verordening

B. Voorschriften voor het machtigen van laboratoria die bevoegd zijn de nodige diensten te verlenen om te controleren of EG-meststoffen aan de voorschriften van deze verordening en de bijlagen ervan voldoen 


\section{Bijlage 3 Verordening (EU) 2019/1009 van het Europees Parlement en de Raad van 5 juni 2019}

De Verordening start met het geven van overwegingen (72) om te komen tot de nieuwe facultatieve Europese meststoffenverordening. De Verordening 2019/1009 is niet van toepassing op producten die ressorteren onder de Verordening voor dierlijke bijproducten (1069/2009) of onder de Verordening voor gewasbeschermingsmiddelen (1107/2009). Daarnaast wordt een afbakening met andere bestaande Uniewetgeving ( 16 Verordeningen) om geen beletsel te vormen betreffende aspecten voor de bescherming van de gezondheid van mensen, dieren en planten, van de veiligheid en van het milieu.

\section{Hoofdstuk I. Algemene bepalingen}

De verordening start met het geven van algemene bepalingen bij het toepassingsgebied voor bemestingsproducten die de CE markering voeren. Begripsomschrijvingen worden geven met generieke bepalingen voor producteisen. Vrij verkeer t.a.v. kwaliteitseisen en het op de markt (EU) aanbieden gereguleerd. Het gebruik wordt niet gereguleerd door EU/2019/1009.

Hoofdstuk II. Verplichtingen van marktdeelnemers

Dit hoofdstuk benoemt de verplichtingen van marktdeelnemers (fabrikanten, importeur (in EU27), distributeurs en gemachtigden) en situaties waarin verplichtingen van fabrikanten van toepassing zijn op importeur (in EU27) en distributeurs. Tenslotte worden voorwaarden gesteld aan de identificatie van de marktdeelnemer en aan verpakken en herverpakken van bemestingsproducten door importeurs (in EU27) en distributeurs.

Hoofdstuk III. Conformiteit van EU bemestingsproducten

Hoofdstuk III geeft generieke bepalingen voor conformiteit en bijhorende specificaties, de onderliggende (EU) conformiteitsprocedures, de beginselen, voorwaarde en procedure voor aanbrengen van de CE markering en de positie van een bemestingsproduct van afvalstoffen voor het verkrijgen van een Einde Afvalstatus.

Hoofdstuk IV. Aanmelding van conformiteitsbeoordelingsinstanties Het proces voor aanmelden van conformiteitsbeoordelingsinstanties wordt in dit hoofdstuk vastgelegd. Het betreft de instanties die bevoegd zijn om conformiteitsbeoordelingstaken van derden in kader van deze verordening te verrichten. Instanties worden door de aanmeldende autoriteit van de lidstaat bij de Commissie en de andere lidstaten. Aanmeldende autoriteiten moeten worden aangewezen door lidstaten. Voor aanmeldende autoriteiten en voor informatieverplichting worden voorschriften gegeven. Voorschriften worden gegeven voor aangemelde conformiteitsbeoordelingsinstanties en hun dochterondernemingen en uitbesteding aan onderaannemers. Verder worden gereguleerd de aanmeldingsprocedure, identificatienummer, betwisting van bekwaamheid, wijziging in aanmelding, operationele verplichtingen, beroep en informatieverplichting. Tenslotte worden bepalingen gegeven voor uitwisseling van ervaringen en de coördinatie door van aangemelde instanties door de Europese Commissie.

Hoofdstuk V. Markttoezicht in de Unie, controle van EU-bemestingsproducten die de markt van de Unie binnenkomen en vrijwaringsprocedure van de Unie

Dit hoofdstuk stelt bepalingen aan markttoezicht in de Unie en controle van EU-bemestingsproducten die de markt van de Unie binnenkomen. De procedures op nationaal niveau worden beschreven voor (potentieel) niet marktconforme bemestingsproducten die een risico inhouden en de Vrijwaringsprocedure van de Unie.

Hoofdstuk VI. Gedelegeerde bevoegdheden en comitéprocedure 
Bepalingen voor bevoegdheden voor wijzigingen en aanvullingen van bijlagen worden gegeven. De bepalingen regelen de bevoegdheid van de Europese Commissie om wijzigingen aan te brengen zonder tussenkomst van het Europees Parlement en de Raad. Ook wordt geregeld wanneer Europees Parlement en de Raad deze bevoegdheidsdelegatie kan intrekken. De Europese Commissie wordt bijgestaan door een Comité. De Comité-procedure wordt beschreven.

Hoofdstuk VII. Wijzigingen

Dit hoofdstuk geeft de afstemming met de Verordening voor dierlijke bijproducten (1069/2009) en de Verordening voor gewasbeschermingsmiddelen ((1107/2009).

Hoofdstuk VIII. Overgangs- en slotbepalingen

Tot slotte worden overgangsbepalingen gegeven voor sancties, evaluatie (verslag) van de nieuwe Europese meststoffenverordening, evaluatie van biologische afbreekbaarheid, intrekken van EG Verordening 2003/2003 en inwerking treding.

Bijlage I. Productfunctiecategorieën (Product Function Categories, PFCs) van EUbemestingsproducten

In deel I worden de 7 PFCs gegeven en in deel II de daaraan gestelde eisen.

Bijlage II. Bestanddelencategorieën (Component Material Categories - CMC's) In deel I worden 11 CMCs gegeven en in deel II de daaraan gestelde eisen.

Bijlage III. Etiketteringsvoorschriften In deel I worden de algemene etiketteringsvoorschriften gegeven en in deel II de productspecifieke etiketteringsvoorschriften. Deel III geeft de regels voor toleranties.

Bijlage IV. Conformiteitsbeoordelingsprocedures

Deel I geeft een leidraad welke conformiteitsprocedure van deel II van toepassing is. Deel II beschrijft vijf conformiteitsprocedures ( $A, A 1, B, C, D 1)$.

Bijlage V. $\quad$ EU conformiteitsverklaring

De bijlage geeft een voorschrift voor de EU-conformiteitsverklaring die uitsluitend onder de verantwoordelijkheid van de fabrikant wordt verstrekt. Indien van toepassing wordt in de verklaring opgenomen de uitvoerende conformiteitsbeoordelingsinstantie met verstrekt certificaat of goedkeuringsbesluit. Bij blends (PFC 7) dienen de EU-conformiteitsverklaringen voor de samenstellende EU-bemestingsproducten van de bemestingsproducten worden toegevoegd. 


\section{Bijlage $4 \quad$ PMCs en de eisen van Duitse regelgeving volgens de Düngemittelverordnung (DüMV).}

\begin{tabular}{|c|c|c|}
\hline PMC & Bemestingsproduct & $\begin{array}{l}\text { DüMV met verwijzing naar relevante } \\
\text { wettelijke bepalingen }\end{array}$ \\
\hline PMC 1, 5\% N & $\begin{array}{l}\text { 6.1 Ammoniumsulfat-Lösung aus der [Bezeichnung nach } \\
\text { Spalte 1] nach Anlage } 1 \text { Nummer } 1.1 .12 \text {. }\end{array}$ & Anlage 1 (1.1.12) Anlage 2, Tabelle 6 (6.1) \\
\hline PMC 2, 10-15\%N & $\begin{array}{l}\text { 6.1 Ammoniumsulfat-Lösung aus der [Bezeichnung nach } \\
\text { Spalte 1] nach Anlage } 1 \text { Nummer } 1.1 .12 \text {. }\end{array}$ & Anlage 1 (1.1.12) Anlage 2, Tabelle 6 (6.1) \\
\hline \multirow[t]{3}{*}{ PMC 3, K-product } & $\begin{array}{l}\text { 1.3.4 Kaliumdünger aus [Bezeichnung nach Anlage } 2 \\
\text { Tabelle } 6.3 \text { Spalte } 1 \text { ] } 3(3.1,3.2) \text { Mineralischer K- }\end{array}$ & $\begin{array}{l}\text { Anlage } 1 \text { abschnitt } 3(3.1,3.2) \text { Anlage } 2 \\
\text { Tabelle } 1\end{array}$ \\
\hline & 3.1. Organischer K-Dünger & $\begin{array}{l}\text { Stoffen nach Anlage 2. Tab. 7.1., } 7.2 \text { sowie } \\
\text { organische stoffen nach Anlage } 2 \text { Tab. } 7.4 \text {. }\end{array}$ \\
\hline & 3.2 Organisch-mineralischer K-Dünger & Stoffen nach Anlache 2 Tab. 7 \\
\hline $\begin{array}{l}\text { PMV 4, Mineraal P- } \\
\text { product }\end{array}$ & $\begin{array}{l}\text { Phosphatdünger aus [Bezeichnung nach Anlage } 2 \text {, } \\
\text { Tabelle } 6.2 \\
6.2 \text { Phosphatdünger aus der [Bezeichnung nach Spalte } \\
\text { 1] nach Anlage } 1 \text { Nummer } 1.2 .9 \\
\text { 6.2.4 Phosphatfällung Fällen mineralischer Phosphate } \\
\text { mit Calciumchlorid, Kalkmilch, Magnesiumchlorid, } \\
\text { Magnesiumoxid oder -hydroxid, Calciumsilikathydrat. }\end{array}$ & $\begin{array}{l}\text { Soweit nicht Düngemittel nach Anlage } 1 \\
\text { Abschnitt } 1.2 \text { Nummer } 1.2 .1 \text { oder Nummer } \\
\text { 1.2.2. Calciumsilikathydrat nur aus } \\
\text { originärer Herstellung, keine Restoder }\end{array}$ \\
\hline \multirow{2}{*}{$\begin{array}{l}\text { PMC 5, P-houdend } \\
\text { OS-product, } 85 \% \\
\text { ds }\end{array}$} & $\begin{array}{l}\text { 3.1 Organischer } \mathrm{N}_{-}, \mathrm{P}_{-}, \mathrm{K}-\text {, } \mathrm{NP}-\text {, NK-, PK ode NPK- } \\
\text { Dünger }\end{array}$ & $\begin{array}{l}\text { Stoffen nach Anlage 2. Tab. 7.1., } 7.2 \text { sowie } \\
\text { organische stoffen nach Anlage } 2 \text { Tab. } 7.4 \text {. }\end{array}$ \\
\hline & $\begin{array}{l}\text { 3.2 Organisch- Mineralischer N-, P-, K-, NP-, NK-, PK } \\
\text { oder NPK-Dünger }\end{array}$ & Stoffen nach Anlache 2 Tab. 7 \\
\hline \multirow[t]{2}{*}{$\begin{array}{l}\text { PMC 6, P-houdend } \\
\text { OS-product, } 50 \% \text { ds }\end{array}$} & $\begin{array}{l}\text { 3.1 Organischer N-, P-, K-, NP-, NK-, PK ode NPK- } \\
\text { Dünger }\end{array}$ & $\begin{array}{l}\text { Stoffen nach Anlage 2. Tab. 7.1., } 7.2 \text { sowie } \\
\text { organische stoffen nach Anlage } 2 \text { Tab. 7.4. }\end{array}$ \\
\hline & $\begin{array}{l}\text { 3.2 Organisch- Mineralischer N-, P-, K-, NP-, NK-, PK } \\
\text { oder NPK-Dünger }\end{array}$ & Stoffen nach Anlache 2 Tab. 7 \\
\hline \multirow[t]{2}{*}{$\begin{array}{l}\text { PMC 7, P-arm os- } \\
\text { product }\end{array}$} & $\begin{array}{l}\text { 3.1 Organischer N-, P-, K-, NP-, NK-, PK ode NPK- } \\
\text { Dünger }\end{array}$ & $\begin{array}{l}\text { Stoffen nach Anlage 2. Tab. 7.1., } 7.2 \text { sowie } \\
\text { organische stoffen nach Anlage } 2 \text { Tab. 7.4. }\end{array}$ \\
\hline & $\begin{array}{l}\text { 3.2 Organisch- Mineralischer N-, P-, K-, NP-, NK-, PK } \\
\text { oder NPK-Dünger }\end{array}$ & Stoffen nach Anlache 2 Tab. 7 \\
\hline
\end{tabular}



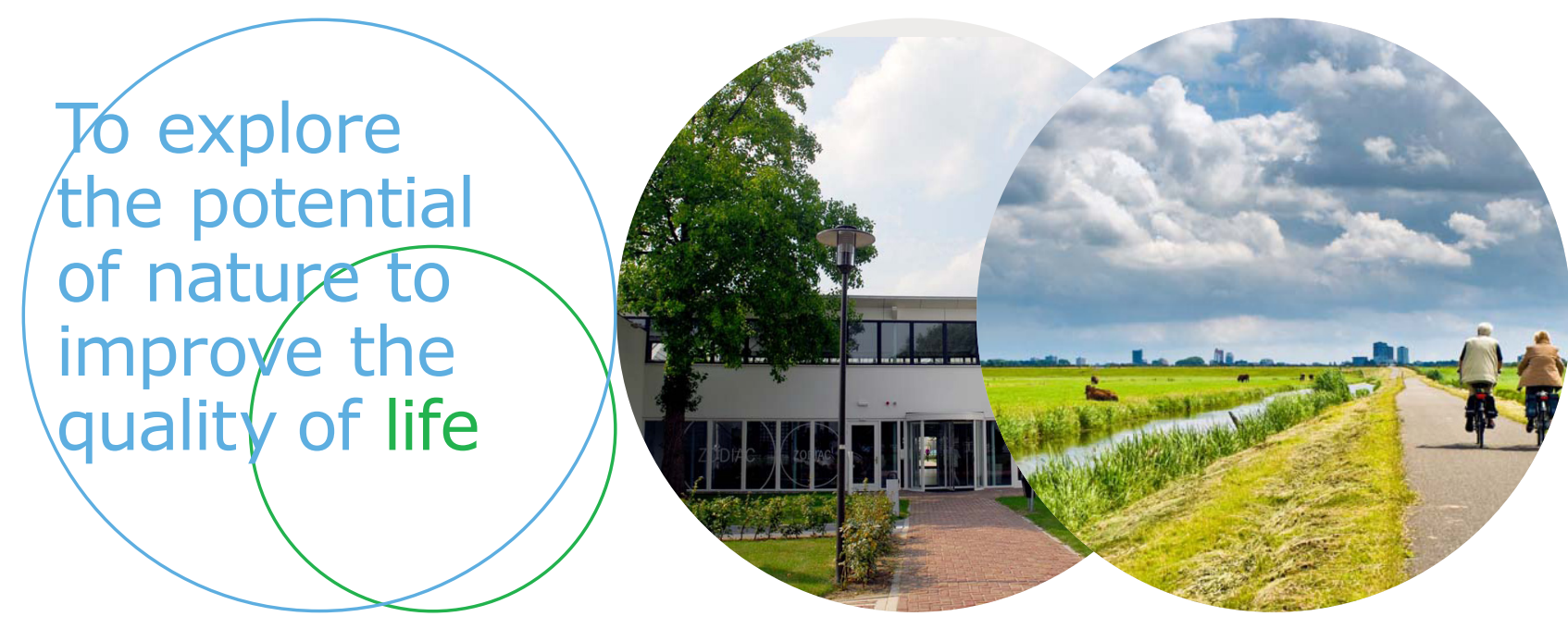

Wageningen Livestock Research Postbus 338

$6700 \mathrm{AH}$ Wageningen

T 0317483953

E info.livestockresearch@wur.nl www.wur.nl/livestock-research
Wageningen Livestock Research ontwikkelt kennis voor een zorgvuldige en renderende veehouderij, vertaalt deze naar praktijkgerichte oplossingen en innovaties, en zorgt voor doorstroming van deze kennis. Onze wetenschappelijke kennis op het gebied van veehouderijsystemen en van voeding, genetica, welzijn en milieu-impact van landbouwhuisdieren integreren we, samen met onze klanten, tot veehouderijconcepten voor de $21 \mathrm{e}$ eeuw.

De missie van Wageningen University \& Research is 'To explore the potential of nature to improve the quality of life'. Binnen Wageningen University \& Research bundelen 9 gespecialiseerde onderzoeksinstituten van Stichting Wageningen Research en Wageningen University hun krachten om bij te dragen aan de oplossing van belangrijke vragen in het domein van gezonde voeding en leefomgeving. Met ongeveer 30 vestigingen, 6.500 medewerkers en 10.000 studenten behoort Wageningen University \& Research wereldwijd tot de aansprekende kennisinstellingen binnen haar domein. De integrale benadering van de vraagstukken en de samenwerking tussen verschillende disciplines vormen het hart van de unieke Wageningen aanpak. 